\title{
Sweden: 2011 Article IV Consultation-Staff Report; Public Information Notice on the Executive Board Discussion; and Statement by the Executive Director for Sweden
}

Under Article IV of the IMF's Articles of Agreement, the IMF holds bilateral discussions with members, usually every year. In the context of the 2011 Article IV consultation with Sweden, the following documents have been released and are included in this package:

- $\quad$ The staff report for the 2011 Article IV consultation, prepared by a staff team of the IMF, following discussions that ended on June 1, 2011, with the officials of Sweden on economic developments and policies. Based on information available at the time of these discussions, the staff report was completed on June 24, 2011. The views expressed in the staff report are those of the staff team and do not necessarily reflect the views of the Executive Board of the IMF.

- $\quad$ A Public Information Notice (PIN) summarizing the views of the Executive Board as expressed during its July 8, 2011 discussion of the staff report that concluded the Article IV consultation.

- A statement by the Executive Director for Sweden.

The policy of publication of staff reports and other documents allows for the deletion of market-sensitive information.

\author{
Copies of this report are available to the public from \\ International Monetary Fund $\bullet$ Publication Services \\ $70019^{\text {th }}$ Street, N.W. $\bullet$ Washington, D.C. 20431 \\ Telephone: (202) 623-7430 • Telefax: (202) 623-7201 \\ E-mail: publications@imf.org Internet: http://www.imf.org
}

\section{International Monetary Fund Washington, D.C.}


INTERNATIONAL MONETARY FUND

\section{SWEDEN}

\section{Staff Report for 2011 Article IV Consultation}

Prepared by Staff Representatives for the 2011 Article IV Consultation with Sweden (in consultation with other Departments)

Approved by Anne-Marie Gulde-Wolf and Claire Waysand

June 24, 2011

Sweden has recovered strongly from the global recession. With growth and strong fiscal credentials spurring significant krona appreciation from mid-crisis lows, inflation is on target but unemployment remains elevated.

Given significant fiscal over-performance relative to the medium-term rule, there is scope to maintain a neutral stance in 2011-12.

The pace of further monetary tightening alongside should remain measured, but should accelerate if the output gap appears to be closing more quickly than estimated or if wage settlements are excessive, and slow if strong krona appreciation continues.

Though the housing market has recently begun to cool, a significant price correction still seems necessary and likely.

While associated financial stability risks seem contained, further measures should be implemented if significant macro prudential or consumer risks are identified. Front-running Basel III requirements and improved internal coordination will enhance stability further.

Consultation discussions were held in Stockholm during May 19-June 1, 2011. The staff team-Mr. Doyle (head), Ms. Babihuga, Mr. Ishi (EUR) and Mr. Gracia (FAD) - met with Finance Minister Borg, Riksbank Governor Ingves, and other senior officials of the government, the Riksbank, the Financial Supervisory Authority (FSA), and the National Debt Office. It also met with the Parliamentary Finance Committee and representatives of the private sector, including financial institutions, the manufacturing association, and the labor union. Mr. Holmberg (OED) also participated in the mission. 


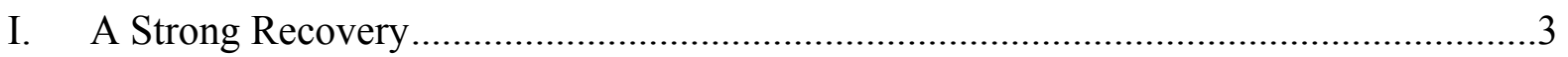

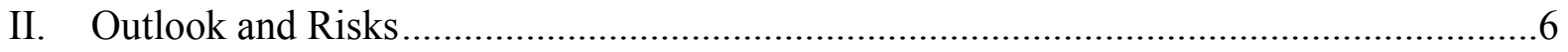

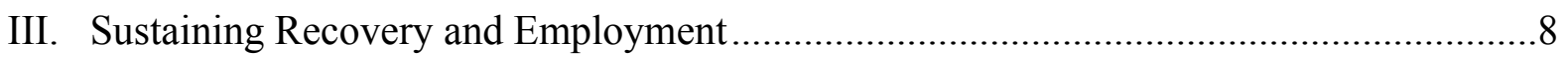

A. Fiscal Policy and Framework ……..................................................................

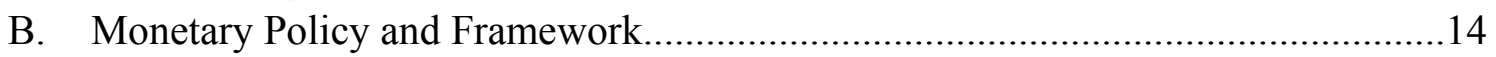

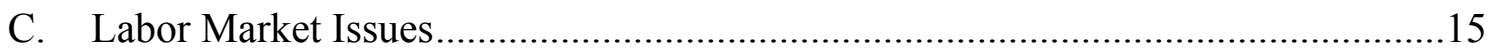

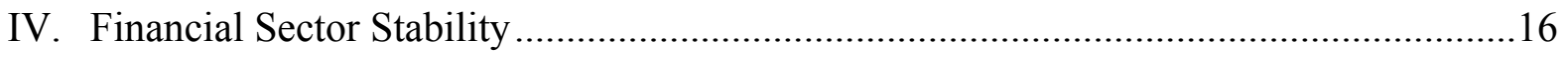

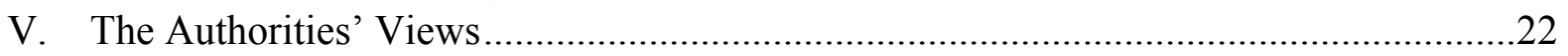

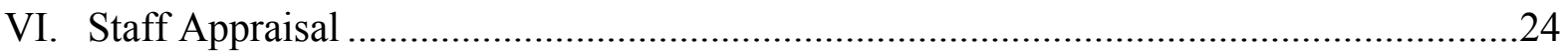

Boxes

1. Competitiveness and the Equilibrium Real Exchange Rate …..........................................

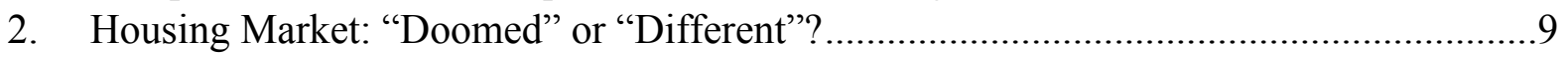

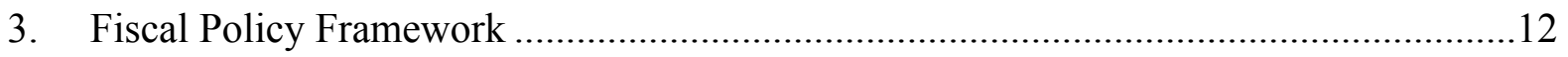

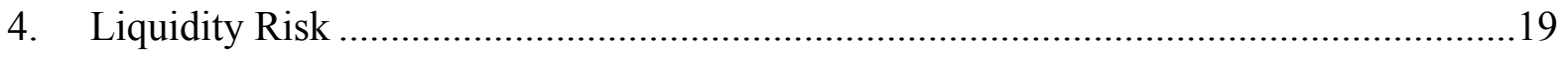

5. The Swedish Covered Bond Market..........................................................................21

Tables

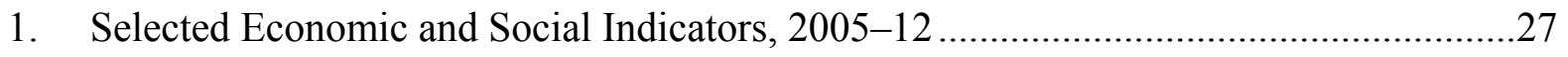

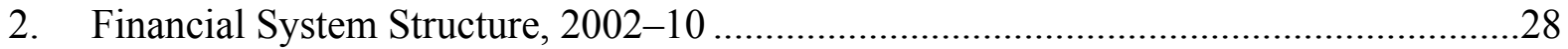

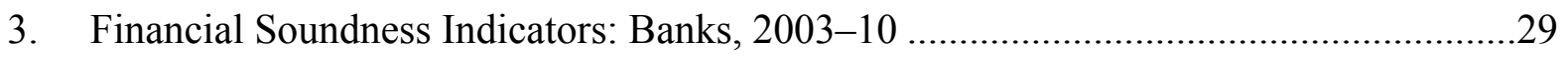

4. Financial Soundness Indicators: Non-Banks, 2003-10 ...............................................30

5. General Government Financial Accounts, 2007-14 ......................................................31

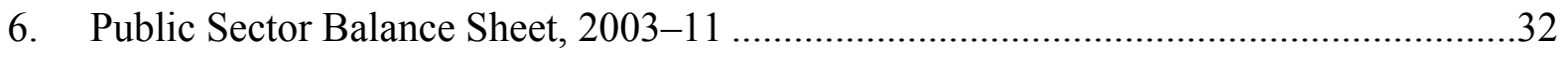

7. Balance of Payments Accounts, 2006-15 .....................................................................33

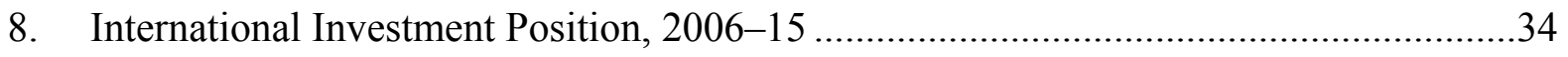

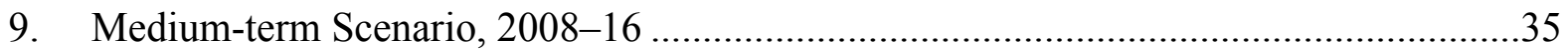

Figures

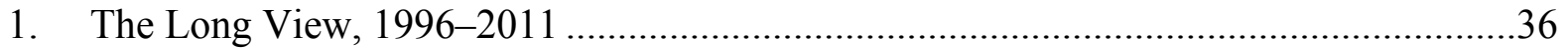

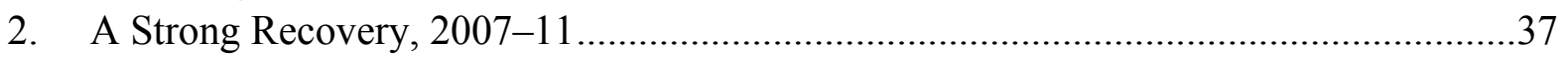

3. Household Balance Sheets and Consumption, 2004-11 ................................................38

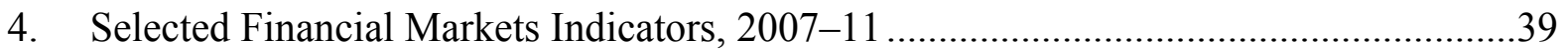

5. Inflation and Monetary Policy, 2007-11 ……...........................................................

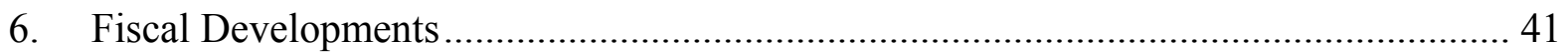

7. Performance of the Swedish Banking System, 2007-11 ..............................................42

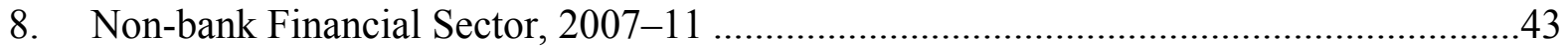

Attachments

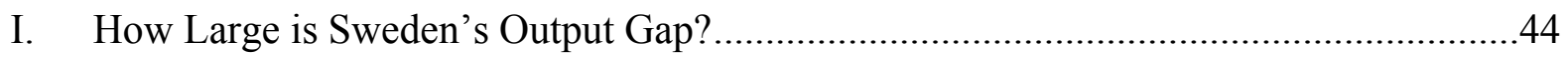

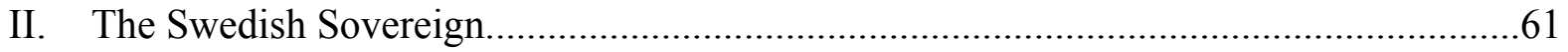

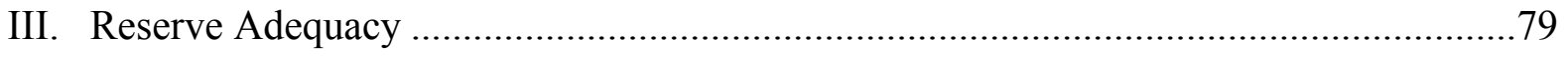




\section{A Strong Recovery}

\section{Sweden grew 5 $1 \frac{1}{2}$ percent in 2010, a leader among advanced economies}

1. Real GDP growth rose at a fast clip from mid-2009, exceeding recoveries elsewhere among advanced economies (Table 1 and Figures $1 \& 2$ ). In part this was because the downturn had been cushioned by the krona's sharp depreciation-from levels that were already somewhat undervaluedboosting exports once global demand began to recover. At the same time, consumption was supported by monetary and fiscal stimulus. Exports have risen by 20 percent, investment by 14 percent and total consumption by $5 \frac{1}{2}$ percent since early2009. And supported by steady lending growth to the household sector, house

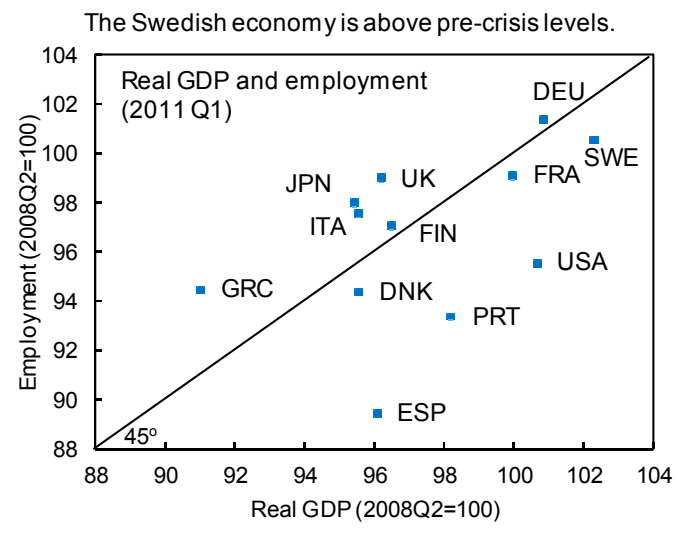
prices continued rising - even through the financial crisis - contrary to the corrections experienced elsewhere (Figure 3). According to staff's estimates, the negative output gap, nearly -6 percent in 2009, narrowed to -3 percent in 2010 .

2. All this has surprised on the upside (text table).

\begin{tabular}{|c|c|}
\hline \multicolumn{2}{|c|}{$\begin{array}{l}\text { Real GDP growth forecasts for } 2010 \\
\text { (percent) }\end{array}$} \\
\hline Riksbank, October 2009 MP Report & 2.2 \\
\hline Ministry of Finance, 2010 Budget Bill $^{1 /}$ & 0.6 \\
\hline IMF, October 2009 WEO & 1.2 \\
\hline Consensus Forecasts, October 2009 & 2.0 \\
\hline
\end{tabular}

3. Total employment has regained pre-crisis levels, with both temporary and permanent employment rising since 2009Q4. But the unemployment rate remains elevated, at close to 8 percent in April 2011, suggesting remaining spare capacity.

4. Momentum continued, albeit slowing somewhat into 2011Q1. GDP rose 0.8 percent quarter-on-quarter, with consumption slowing more markedly. Inventories continued strong increases.

5. With improved macroeconomic conditions, the financial system has regained strength (Tables 2, 3, \&4). Stock market indices are approaching pre-crisis peaks (Figure 4). Money market spreads have remained above pre-crisis levels following the withdrawal of official 
emergency liquidity support. Bank capital adequacy ratios have strengthened, and bank credit default swap spreads remain well below the average of other European banks.

\section{This has been achieved in the context of a measured withdrawal of policy stimulus}

6. Exit from the crisis intervention measures commenced in the Spring of 2010. The Riksbank stopped offering 3 and 6 month loans, replaced by 28 day loans with a penal rate and was among the first of advanced economy central banks to begin a tightening cycle, in July 2010, after the global crisis. The policy rate was raised by 150 basis points to $13 / 4$ percent (Figure 5). By the end of 2010, the Riksbank had terminated all crisis-time liquidity measures and its balance sheet had contracted markedly. The government has kept the bank debt guarantee and bank recapitalization programs open, but currently there is no use of these programs.

7. Rather than widening to over 2 percent of GDP as projected by both staff and the authorities, the fiscal deficit narrowed from 0.9 percent of GDP in 2009 to 0.3 percent of GDP in 2010, largely as automatic stabilizers responded to record growth (Tables $5 \& 6$ and Figure 6). Hence, the fiscal is estimated to have been broadly neutral, $1 \frac{1 / 2}{2}$ a percentage point of GDP smaller-than-projected.

8. Strong growth and fiscal performance alongside capital inflows was reflected in significant krona appreciation (Tables 7 \& 8). Since the March 2009 mid-global crisis trough, the krona appreciated by 23 percent in real effective terms - more than reversing its depreciation during the crisis — as market concerns about sustainability in Europe intensified. Throughout, the Riksbank eschewed discretionary intervention, accommodating both the depreciation and subsequent appreciation (Box 1).

\section{Box 1. Competitiveness and the Equilibrium Real Exchange Rate}

Following its 23 percent real effective appreciation from its mid-2009 trough, the krona remains competitive, with qualitative caveats to the standard measures not significantly affecting this assessment (text table):

- $\quad$ Population ageing calls for a mediumterm strengthening of the net external position.

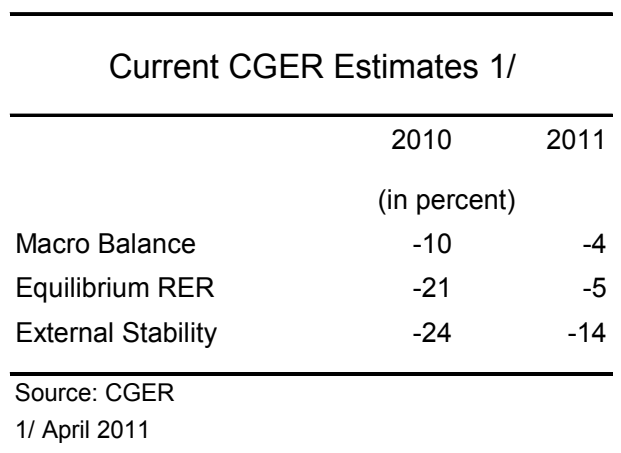

- $\quad$ The MB and ES measures are qualified by risks that staff medium term macro projections may fail to appropriately reflect a possible drop in consumer durables and investment goods demand that might have resulted from the recent crisis.

- Alongside other indicators, the staff assessment is that the currency is competitive. 


\section{The crisis has mixed legacies}

9. On the upside, exports have recovered. With demand sluggish in a number of its traditional export markets, Sweden re-directed exports to other markets, away from Europe and towards emerging markets, notably China.

10. Further, despite the upswing in growth and surging commodity prices, inflation has remained stable, partly due to the krona's appreciation. Underlying inflation is stable around the 2 percent target, although headline inflation has been rising somewhat mainly due to mortgage interest costs directly affected by policy interest rate changes.

11. And reflecting the external nature of the shock, the lasting impact on potential growth appears to have been negligible. Staff estimates point to a decline in the growth rate of potential real GDP of -0.5 percent in 2008-09 compared to 3 percent on average in 1997-2007, resulting from the decline in productivity growth, the capital stock and the increase in structural unemployment. Potential GDP is estimated to have risen by 1 percent during the recovery, reflecting renewed investment and productivity growth.

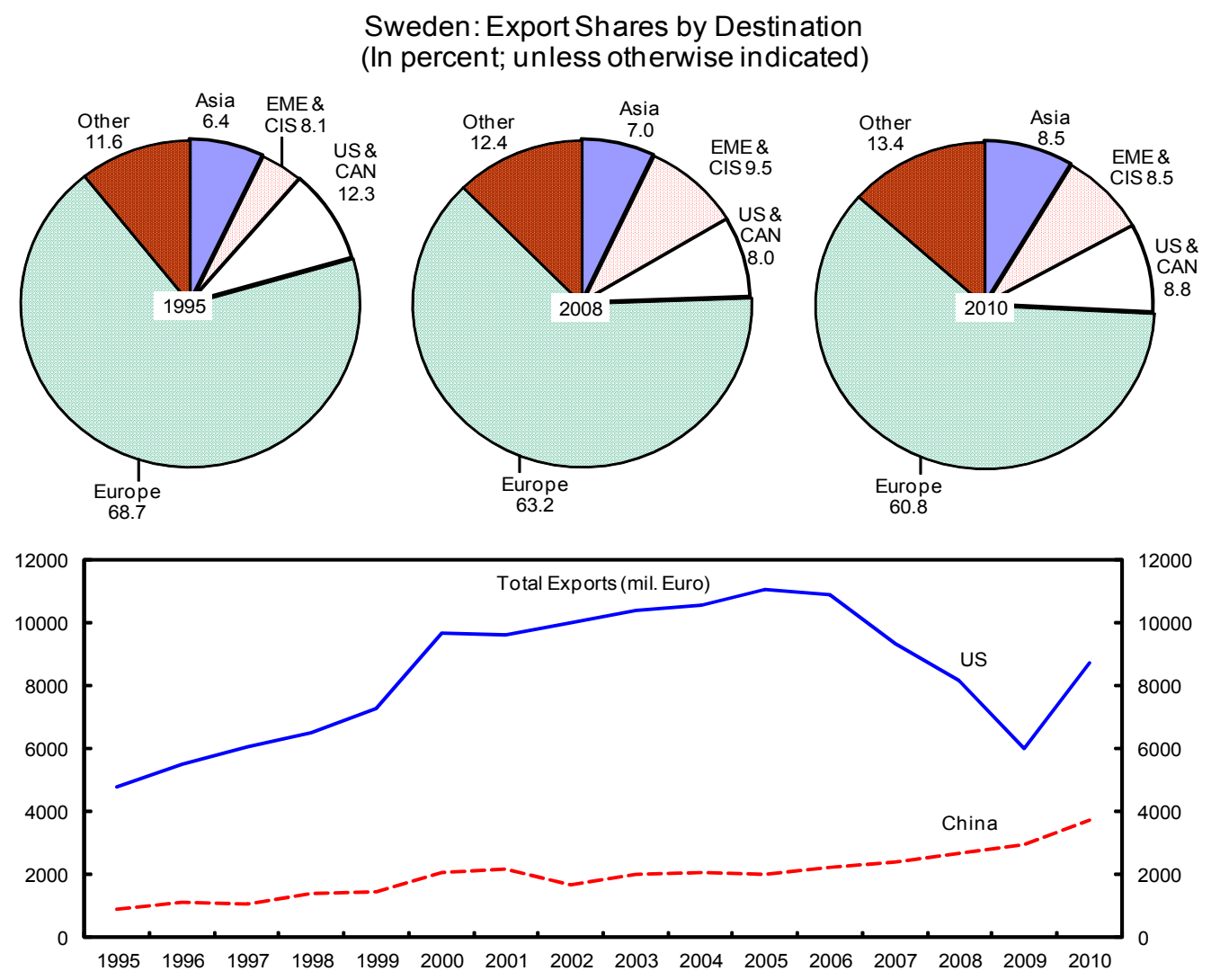

Source: Statistics Sweden. 
12. On the other hand, estimates suggest that structural unemployment has risen somewhat (see Attachment I). The unemployment rate increased significantly, peaking at close to 10 percent in early-2010. Both its increase and persistence could have resulted into spillover to the structural rate, even though its level is considerably lower than was anticipated at the onset of the financial crisis. Moreover, there has been a significant increase in the number of long-term unemployed-it more than doubled during the crisis and remains one and a half times the pre-crisis level.

13. And the output gap remains unclosed, at some 3 percent of GDP in 2010 (see Attachment II). Although manufacturing capacity utilization had returned by end 2010 to pre-crisis averages, unemployment remains high, and investment is increasing capacity.

\section{OUTLOOK AND RISKS}

\section{The external environment has improved}

14. External trade comprises over 90 percent of GDP, and total financial sector assets sum to 550 percent of GDP, 40 percent of which are direct foreign exposures.

\begin{tabular}{|c|c|c|c|c|c|c|}
\hline & & World & conomic Outlo & k (WEO) & & \\
\hline & \multirow[t]{2}{*}{2009} & \multirow[t]{2}{*}{2010} & \multicolumn{2}{|c|}{2011} & \multicolumn{2}{|c|}{2012} \\
\hline & & & \multicolumn{4}{|c|}{ Projections } \\
\hline \multicolumn{7}{|l|}{ GDP growth } \\
\hline World & -0.5 & 5.0 & & & & \\
\hline European Union & -4.1 & 1.8 & & & & \\
\hline Germany & -4.7 & 3.5 & & & & \\
\hline Sweden & -5.3 & 5.5 & & & & \\
\hline \multicolumn{7}{|c|}{90 percent confidence interval } \\
\hline & & & Lower bound & Upper bound & Lower bound & Upper bound \\
\hline \multicolumn{7}{|l|}{ GDP growth } \\
\hline World & $\ldots$ & $\ldots$ & 2.4 & 6.1 & 1.9 & 7.2 \\
\hline Sweden & $\ldots$ & $\ldots$ & 2.6 & 6.1 & 2.1 & 5.6 \\
\hline
\end{tabular}

Sources: WEO projections (Apr-2011) and staff estimates.

15. The broader global outlook is slightly improved since the Fall 2010 WEO. While the central projection for world growth in 2011-12 is roughly unchanged, the 90 percent confidence interval around these global projections has narrowed by some $1 \frac{1}{2}$ percentage points (see text table). But these prospects are bifurcated, with emerging and developing economies projected to grow at $6 \frac{1}{2}$ percent and advanced economies growing at $2 \frac{1}{2}$ percent.

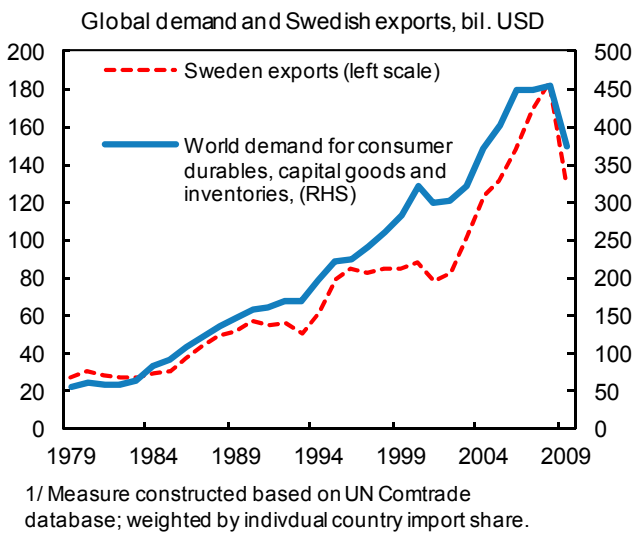


16. Sweden's exports depend critically on global demand for consumer durables, capital goods and inventories. While the global upswing in inventories has buoyed Swedish exports in 2010, balance sheet and fiscal retrenchment in advanced countries may dent demand there for consumer durables and capital goods in the medium term, making Sweden increasingly dependent on alternative markets. And the krona remains under upward pressure, reflecting ongoing market stress in Europe and a continued "search for strong sovereigns", as well as the Riksbank's monetary tightening.

\section{Some loss of growth momentum is expected in Sweden}

17. The Riksbank forecasts real GDP growth of 4.6 percent in 2011, with 90 percent confidence intervals ranging from 2.5 percent to 7.6 percent.

18. In staff's central case, growth is projected to slow to 4.4 percent in 2011 and 3.8 percent in 2012, as the rebound's temporary factors unwind, fiscal consolidation in Europe slows external demand and krona appreciation weighs on exports (text figure \& Table 9). Near term growth will depend on private consumption and investment as the overall policy stance remains supportive - interest rates are still low and the krona remains competitive, and asset markets are buoyant. Exports will grow at a slower pace, reflecting strong economic growth in non-traditional export markets.

\begin{tabular}{|c|c|c|c|c|c|c|c|c|c|c|}
\hline \multicolumn{11}{|c|}{$\begin{array}{l}\text { Sweden: Near Term Economic Developments, 2011-12 } \\
\text { (percent change, quarter-over-quarter, seasonally-adjusted) }\end{array}$} \\
\hline & \multicolumn{5}{|c|}{2011} & \multicolumn{5}{|c|}{2012} \\
\hline & Q1 & Q2 & Q3 & Q4 & Annual & Q1 & Q2 & Q3 & Q4 & Annual \\
\hline Real GDP & 0.8 & 0.6 & 0.6 & 0.6 & 4.4 & 1.2 & 1.2 & 1.2 & 1.1 & 3.8 \\
\hline Private Consumption & 0.4 & 0.7 & 0.7 & 0.5 & 2.5 & 0.6 & 0.6 & 0.5 & 0.5 & 2.4 \\
\hline Public Consumption & -0.2 & 0.1 & -0.1 & 0.0 & 1.0 & 0.4 & 0.4 & 0.6 & 0.4 & 1.2 \\
\hline Gross Fixed Capital Formation & 1.6 & 3.1 & 1.8 & 1.0 & 8.9 & 2.9 & 2.9 & 2.9 & 2.9 & 10.0 \\
\hline Exports & 2.3 & 2.2 & 1.1 & 0.9 & 9.4 & 1.7 & 1.7 & 1.7 & 1.7 & 6.2 \\
\hline Imports & 1.5 & 1.4 & 1.5 & 0.8 & 7.0 & 1.5 & 1.5 & 1.5 & 1.5 & 5.6 \\
\hline $\mathrm{CPI}$ & 0.8 & 0.8 & 0.8 & 0.8 & 3.0 & 0.5 & 0.5 & 0.5 & 0.5 & 2.5 \\
\hline GDP Deflator & 0.1 & 1.5 & 4.7 & -4.1 & 3.1 & 0.1 & 0.1 & 4.7 & -4.1 & 2.5 \\
\hline Nominal GDP & 1.0 & 2.0 & 5.3 & -3.6 & 7.6 & 1.3 & 2.7 & 6.0 & -3.0 & 6.4 \\
\hline
\end{tabular}

Sources: Statistics Sweden and IMF staff projections.

19. The staff central case scenario implies the output gap closing early in 2012. The gap is projected at around 1-2 percent in 2011. However, if potential growth disappoints, perhaps as a consequence of sustained unemployment, the gap could close more quickly.

\section{Risks}

20. On the external side, higher-than-projected oil prices pose a downside risk to global growth prospects. In an adverse scenario prepared by the WEO, a temporary surge in oil prices to $\$ 150$ per barrel in 2011 - 40 percent higher than the baseline-lowers global growth in 2012 by two-thirds of a percentage point, with output losses much larger in the event of a permanent shock. However, as oil intensity of output is low, the real and inflationary implications are attenuated. 
21. Downside risks also stem from continued strains in the euro area periphery's sovereigns and banking systems. On WEO estimates, in a scenario in which these strains spillover into the core, euro area growth could be lowered by 3 percentage points and global output by 1 percentage point relative to the baseline WEO forecast.

22. On the domestic side, concerns focus on the housing market (see Box 2). In particular, large house price falls could lower consumption growth markedly, as has occurred elsewhere (text figure).

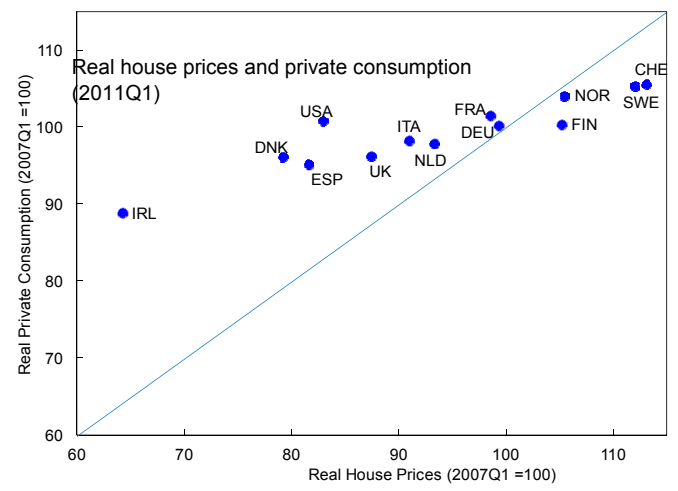

\section{SUSTAINING RECOVERY AND EMPLOYMENT}

\section{A. Fiscal Policy and Framework}

Given that Sweden's sovereign credentials are firm, fiscal policy has the latitude to continue to support output in the short term as the output gap closes. But external tail risks call for the maintenance of sizeable buffers relative to the fiscal rules.

\section{For 2009-10, strong fiscal support to demand was planned}

23. To address possible weak global conditions and their spillovers to the domestic economy, an expansionary fiscal stance for 2010 was anticipated. In contrast to countries facing financing and/or sustainability concerns, Sweden's strong fiscal credentials provided room for this maneuver. ${ }^{1}$ Thus, discretionary measures summing to some 4 percentage points of GDP, of which 0.7 percent of GDP are crisis-related spending stimulus measures, across 2009-10 were planned (see text table). However, the execution of stimulus measures was incomplete, particularly at the local level.

\begin{tabular}{lrr}
\multicolumn{3}{c}{$\begin{array}{c}\text { Sweden: Fiscal Measures 2009-10 } \\
\text { (In percent of GDP) }\end{array}$} \\
\hline Total & 2009 & 2010 \\
2009 Spring Fiscal Policy Bill (April 2009) & 0.2 & 2.3 \\
Additional ALMPs 1/ & 0.2 & 0.3 \\
& & 0.3 \\
2010 Budget Bill (September 2009) & 1.0 \\
Moderate the fall in employment & 0.3 \\
Prevent unemployment from becoming persistent & 0.4 \\
Defending welfare & 0.2 \\
More business starts and business growth & 0.1 \\
Protecting the climate & 0.0 \\
Other & 0.0 \\
2010 Spring Fiscal Policy Bill (April 2010) & 0.9 \\
Temporary Crisis Measures & 0.4 \\
Increase permanent level of employment & 0.4 \\
Welfare & 0.2 \\
\hline
\end{tabular}

Source: 2009, 2010 Budget Bills and 2009, 2010 Spring Bills.

1/ Active labor market policies

\footnotetext{
${ }^{1}$ See Attachment II.
} 


\section{Box 2: Sweden's Housing Market: “Doomed" or "Different"?}

The housing market has some echoes of recent boom-bust cases elsewhere. Like Denmark, Ireland, Spain, the U.K. and the U.S., house prices and private debt have risen substantially, and price to income and price to rent ratios are above historical norms. Is Sweden's housing boom doomed to the same bust?
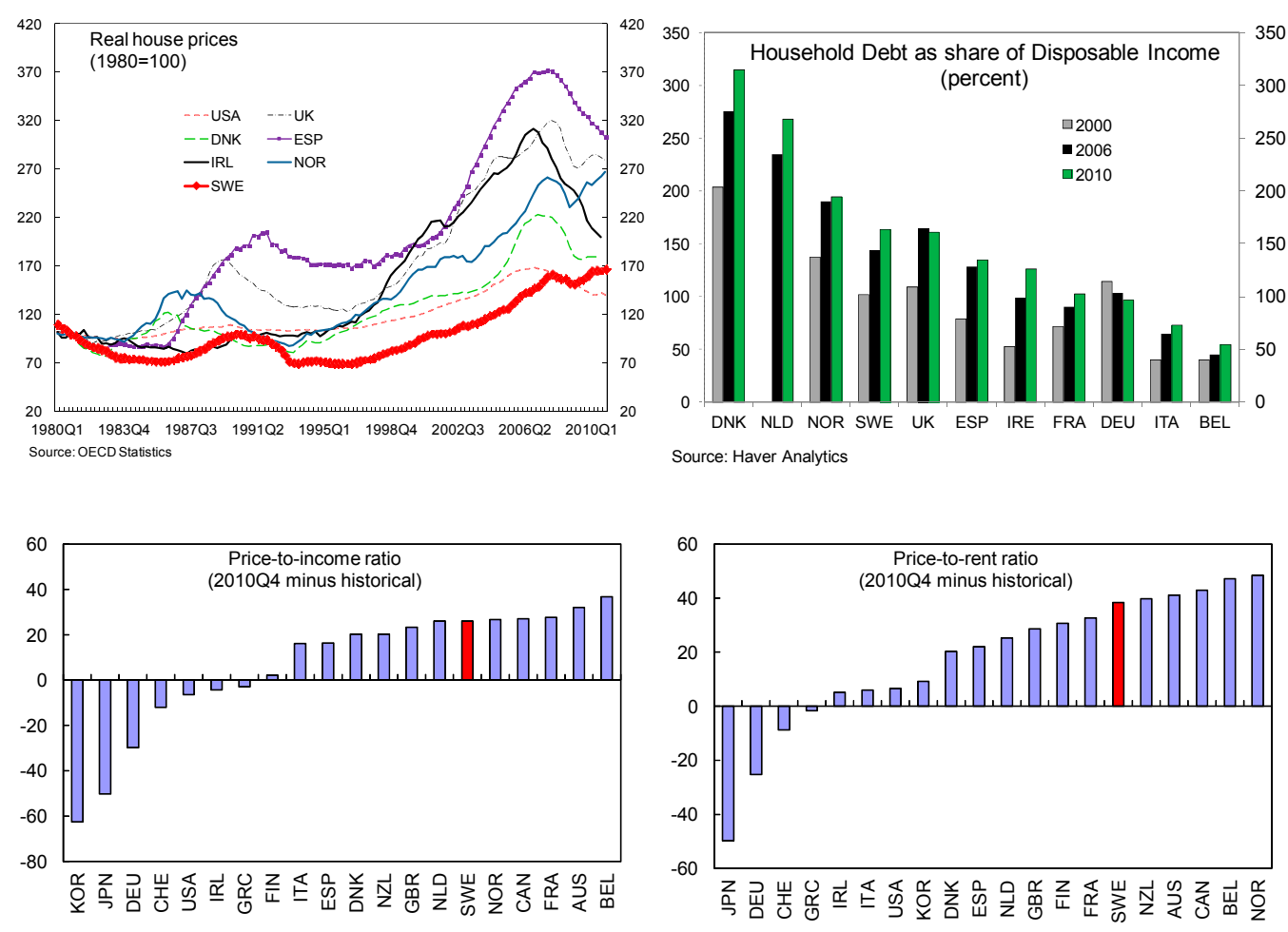

Source: OECD.

Sweden is similar in some ways to these cases, but is not the same. Since the 1980 s, house price inflation has fallen well short of the major European bust cases, although it is close to the U.S. Further, there has been no surge in residential investment, which was curbed by the strict rent control system in the main cities. And pre-crisis lending growth has been more tempered in Sweden and targeted at households, not property developers.
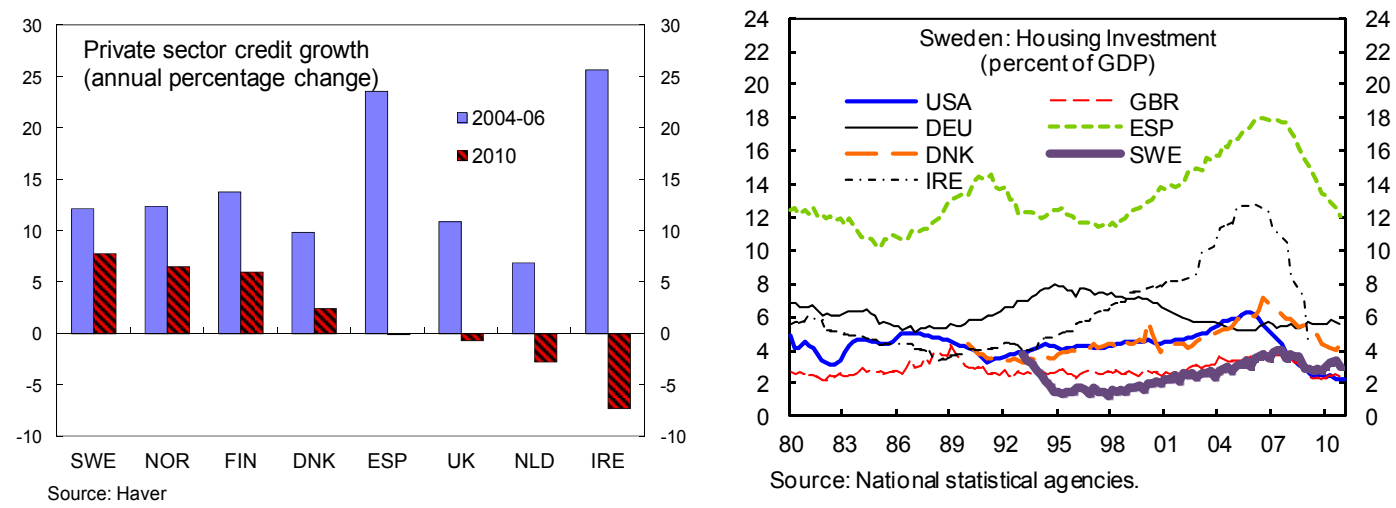


\section{Box 2: Sweden's Housing Market: “Doomed” or "Different”? (Continued)}

There is also some institutional reassurance of the quality of the underlying lending. In particular, mortgages are predominantly financed through covered bonds, and the issuing banks remain permanently liable for the quality of the underlying mortgages. For comparison, Denmark has similar arrangements and saw negligible mortgage losses resulting from the recent 20 percent housing market correction. This assessment is corroborated by data on the distribution of mortgage credit by risk class, but these data are only partial and a broader perspective on this breakdown is needed (Text figure).

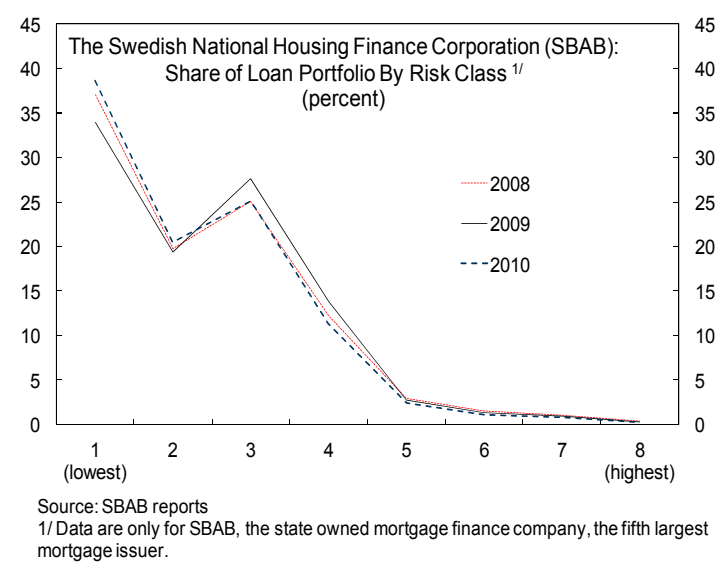

An extensive recent Riksbank study is skeptical of the risk of house price declines, noting that even recent price movements can be explained by "fundamentals", such as low nominal interest rates. On the other hand, the Swedish National Housing Credit Guarantee Board is less sanguine. It suggests house prices are overvalued by some $20-25$ percent.

Furthermore, actions have already been taken which will cool the market — and there are signs that they have begun to be effective. The nominal policy rate of the Riksbank has been raised and further increases are expected. And the financial supervisor imposed interest rate penalties on mortgages with loan-to-value ratios exceeding 85 percent from October 2010.

The Riksbank finds that even if prices fall, various factors attenuate the associated financial stability risks: (i) borrowers are subject to direct and life-long personal liability even after default and foreclosure procedures, which limits banks' mortgage losses; (ii) the well developed public insurance system cushions borrowers' income during downturns; and (iii) there is no buy-to-let market.

In summary, there is significant risk of a decline in house prices in coming years, even in a relatively benign global economic scenario. Rising nominal interest rates are likely to be the catalyst, supported by the micro-prudential measures taken by the financial supervisors. However, this is not likely to cause significant macroeconomic disruption -with the construction sector relatively small, and broader household confidence buoyed by global recovery - unless it is disorderly. In that case consumption could be significantly affected. There is limited evidence that house price declines —of even significant magnitude - pose significant financial stability risks.

Only in the event of multiple shocks - a perfect storm - including euro area strains transmitting to the core is there risk of significant difficulties in the Swedish housing market. However, even in this case, the consequences of the broader crisis will be difficult to distinguish from those arising more narrowly from the domestic housing market which they would cause and through which they would flow. 


\section{The 2010 real and fiscal outturns were considerably better than anticipated}

24. The output gap - however measured - was well below expectations, as was

unemployment. In this context, the general government overall balance outturn, -0.3 percent of GDP, was almost 2 percentage points of

GDP stronger than the authorities

anticipated in the Spring of 2010, with the estimates of the 2010 outturn improving through the year with every vintage of the estimates for them (text table). Sick-leave and early retirement reforms continued to deliver savings on the expenditure side. These factors outweighed discretionary deficit increasing measures of some

\begin{tabular}{lcccccc}
\multicolumn{7}{c}{ Sweden: 2010 Fiscal Performance } \\
\hline & $\begin{array}{c}2010 \\
\text { Budget }\end{array}$ & $\begin{array}{c}2010 \text { Spring } \\
\text { Bill }\end{array}$ & $\begin{array}{c}2011 \\
\text { Budget }\end{array}$ & \multicolumn{2}{c}{ Prel. } \\
\cline { 2 - 5 } \cline { 4 - 7 } Revenues & 51.7 & 51.1 & 50.2 & 50.7 & SB $^{1 /}$ & IMF \\
Expenditures & 55.1 & 53.2 & 51.4 & 51.1 & \\
Net lending & -3.4 & -2.1 & -1.3 & -0.3 & \\
$\quad$ Central gov. & -3.5 & -2.3 & -1.6 & -0.5 & \\
Structural balance & 0.2 & 0.4 & 0.6 & 1.8 & 1.4 \\
Output gap & -6.5 & -4.4 & -3.3 & -3.8 & -3.1 \\
Unemployment rate & 11.4 & 9.2 & 8.4 & 8.4 & 8.4 \\
\hline Source: Ministry of Finance and staff projections & & & \\
1/ 2011 Spring Bill incorporates preliminary 2010 fiscal figures & &
\end{tabular}

2.3 percentage points, with roughly two-thirds focused on tax measures - permanent cuts in personal tax and social contributions. Crisis related stimulus measures on the spending side, including local government grants to support public sector employment and welfare, amounted to 0.1 percent of GDP. The structural surplus was also stronger by more than 1 percentage point of GDP than first projected, and at 1.4 percent of GDP, its outturn is significantly larger than required to observe the fiscal rule (see Box 3).

\section{The underlying fiscal stance should remain unchanged in 2011-12}

25. As in 2010, the 2011 budget strikes a balance between supporting demand and reinforcing underlying credentials - rightly shifting emphasis to the latter as the economy recovers. Accordingly, its focus is on strengthening the supply side spending initiatives by 0.4 percent of GDP in 2011 to further encourage long term employment and labor supply, strengthen welfare and improve the environment. The long-term impact of labor market related measures is estimated at 250,000 new jobs by 2015 and a reduction of the equilibrium rate of unemployment from $6 \frac{1}{2}$ in 2006 to 5 percent by 2015 .

Sweden: Medium-Term Fiscal Outlook

\begin{tabular}{|c|c|c|c|c|c|c|c|c|c|c|c|}
\hline & \multicolumn{2}{|c|}{2010} & \multicolumn{3}{|c|}{2011} & \multicolumn{2}{|c|}{2012} & \multicolumn{2}{|c|}{2013} & \multicolumn{2}{|c|}{2014} \\
\hline & Bud. 1/ & SB 2/ & Bud. & SB 2/ & IMF & SB 2/ & IMF & SB 2/ & IMF & SB 2/ & IMF \\
\hline Revenues & 51.7 & 50.7 & 49.4 & 50.1 & 49.3 & 50.3 & 48.6 & 50.2 & 48.6 & 50.2 & 48.4 \\
\hline Expenditures & 55.1 & 51.1 & 49.8 & 49.8 & 48.4 & 48.5 & 47.3 & 47.4 & 46.8 & 46.6 & 46.4 \\
\hline $\begin{array}{l}\text { Net lending } \\
\text { of which: }\end{array}$ & -3.4 & -0.3 & -0.4 & 0.3 & 0.8 & 1.8 & 1.3 & 2.8 & 1.7 & 3.6 & 2.0 \\
\hline central gov. & -3.5 & -0.5 & -0.6 & 0.1 & 0.6 & 1.7 & 1.1 & 2.7 & 1.6 & 3.5 & 1.8 \\
\hline pension syst. & 0.1 & 0.2 & 0.4 & 0.4 & 0.5 & 0.3 & 0.4 & 0.2 & 0.2 & 0.2 & 0.3 \\
\hline local gov. & 0.0 & 0.1 & -0.2 & -0.2 & -0.2 & -0.2 & -0.1 & -0.1 & -0.1 & -0.1 & -0.1 \\
\hline Structural balance 3 / & $\ldots$ & 1.4 & $\ldots$ & $\ldots$ & 1.3 & $\ldots$ & 1.2 & $\ldots$ & 1.5 & $\ldots$ & 1.9 \\
\hline Structural balance 4/ & 0.2 & 1.9 & 1.0 & 1.4 & $\ldots$ & 2.2 & $\ldots$ & 2.9 & $\ldots$ & 3.6 & $\ldots$ \\
\hline Output gap & -6.5 & -3.1 & -2.5 & -1.9 & -1.6 & -0.7 & -0.9 & -0.1 & -0.1 & 0.1 & 0.1 \\
\hline
\end{tabular}

Source: Ministry of Finance and staff projections

1/ Original 2010 budget:

2/ 2011 Spring Bill;

3/ Staff Estimates;

4/ Authorities' Estimates. 


\section{Box 3: Fiscal Policy Framework}

The fiscal framework has three key elements: (i) an unlegislated surplus target established at 1 percent of GDP over the business cycle; (ii) a rolling central government nominal expenditure ceiling established for three years ahead, with a new "third year ceiling added each year, and (iii) a balanced budget requirement for local governments. In implementing this, the Riksdag first sets the total expenditure allocations. Appropriations within that ceiling are determined separately and later. Nominal expenditure ceilings, once established, have not been revised beyond technical adjustments providing predictability to government spending.

During the recent economic crisis, of the five indicators used by the authorities to assess compliance with the framework, only the backward looking 10 year net lending average is marginally below the 1 percent surplus target in 2010 and is projected to remain below in 2011. All other indicators are above the fiscal target, some with considerable margin, including the structural balance. Though staff estimates of structural fiscal balances differ from those of the authorities, these also show overperformance relative to the rules (see Attachment II).
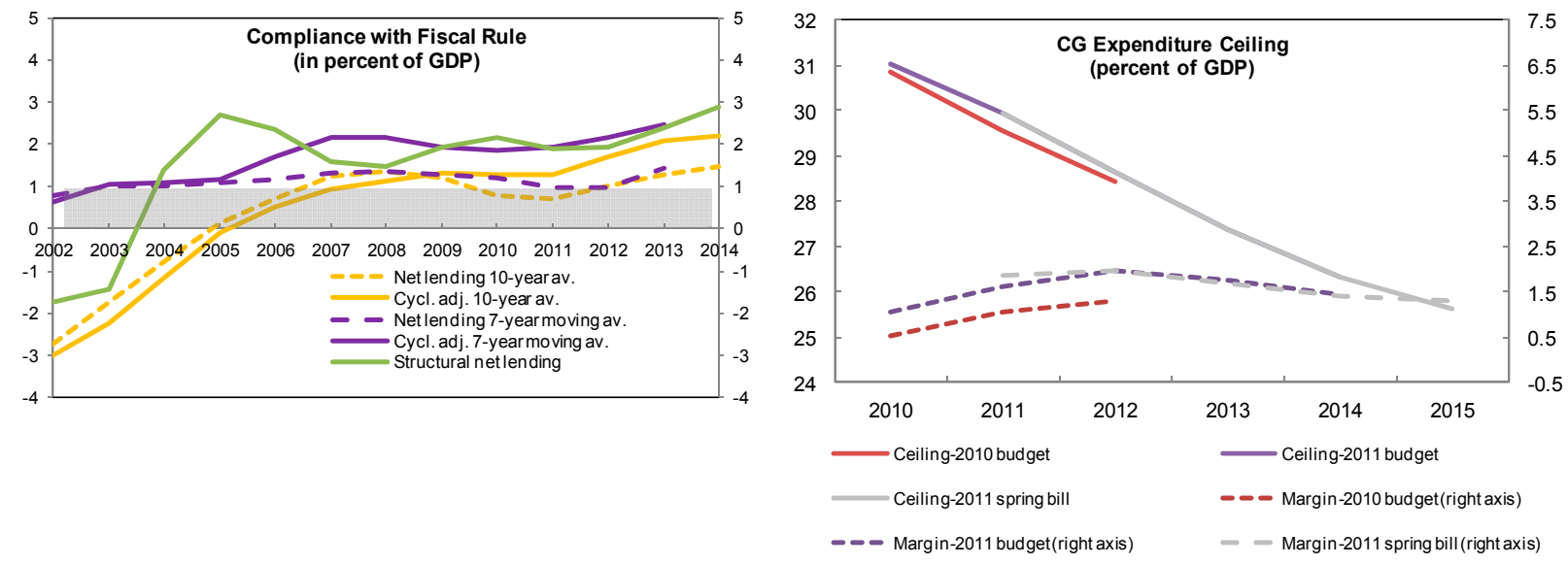

The 2011 budget adds three additional features to the standard framework, all aimed to underscore the authorities' caution. First, the horizon for the expenditure ceiling was extended from three to four years ahead (text figure). This is intended to underpin confidence in the sustainability of the return to fiscal surpluses. Second, building on earlier practice, the appropriated expenditures to 2014 have been set below the expenditure ceiling by 1 percentage point of GDP annually - a considerably increased "safety margin", even though the assessment of risks has been adjusted from "downside" to "balanced". Large years-ahead budgetary margins should be taken with caution as they will be automatically reduced with permanent fiscal reforms approved in prior years. And, third, preferring to make "permanent" fiscal reforms only once the domestic and international outlook is more certain, the authorities have postponed to 2012 their ambitions for tax reductions. 
26. In the absence of new initiatives, the structural balance strengthens automatically, in part due to fiscal drag and the non-indexation of key expenditures, as reflected in the authorities' projections. This creates space for new measures, consistent with staff advice to maintain the structural fiscal balance. Rather than using this available fiscal space for planned tax reductions in 2011, the authorities have maintained an extra fiscal buffer in view of remaining domestic and external macroeconomic uncertainties. However, they plan tax reductions in 2012 up to 0.7 percent of GDP, provided structural education and welfare reforms are also approved. Tax measures under consideration include, among others, reinforcing the in-work tax credit, raising the lower income tax bracket for the state income tax, reducing taxes for pensioners, reducing the income tax for residents abroad, reducing the VAT on restaurants and catering services, and increasing the excise tax on alcohol and tobacco. On the spending side, education and infrastructure investment will also be priorities in the 2012 budget.

\section{Fiscal policy is set to over-perform in the medium term}

27. The authorities are building sizeable fiscal buffers by increasing the "safety margins" between the spending ceilings and appropriated spending. While the fiscal risks even in the event of a dramatic domestic housing market downturn are minor, increased margins are key to address elevated external tail risks, particularly those coming from the euro area ${ }^{2}$.

28. Even so, this allows a broadly neutral fiscal stance in 2011 and 2012. Only in the unlikely event of significant sustained krona overvaluation would there be need to shift the underlying stance for 2012 to a tightening.

29. Thus, the stage is set for more permanent fiscal reforms in 2012 and these are rightly focused on increasing labor participation. The income-tax credits reduce the tax wedge for low earners while reducing the state income tax could increase hours worked by increasing the marginal effective tax rate. Other measures under consideration, particularly the reduction in the VAT on restaurants, have more questionable impact on labor demand and lower overall compliance.

\section{The Fiscal Policy Council remains a pillar of the system}

30. Its tasks include evaluation of the extent to which medium-term fiscal policy goals are being achieved and the quality of forecasts. To be a fully effective watchdog, it needs to be adequately resourced in a way that secures confidence in its technical expertise, continuity and independence. And its mandate needs to be more narrowly focused on assessing the fiscal stance and conformity of policy with medium-term stability and sustainability goals.

\footnotetext{
${ }^{2}$ Direct taxation from housing is limited even for local governments. Thus, the fiscal stance is affected more by broader macroeconomic downturns than by narrower housing market developments.
} 


\section{B. Monetary Policy and Framework}

Monetary policy rates should continue to rise steadily given that the krona is still competitive and housing richly valued.

\section{Inflation has been moderate}

31. Headline inflation has risen back to the target of 2 percent, whereas inflation excluding mortgage interest costs has remained somewhat lower at $1 \frac{1}{2}$ percent. Upward pressures arising from higher energy and commodity prices have been partially offset by the stronger krona, while nominal wage growth has remained contained, and house price growth has flattened.

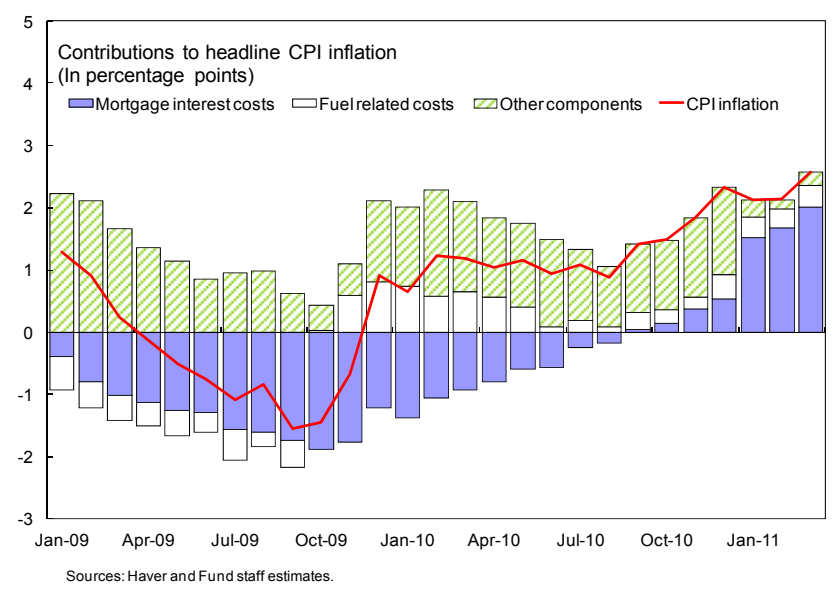

\section{Nevertheless, with recovery, inflation risks have risen}

32. Although unemployment remains high compared to its pre-crisis level, and the output gap, though falling, appears to remain significant, capacity utilization has returned to an historical average and business surveys indicate desire to raise employment further in some sectors. New wage negotiation rounds for 2011-12 will commence in Fall 2011.

\section{Thus, a tightening cycle has began, with further increases indicated}

33. Since July 2010 , the near-zero policy interest rate has been raised to $13 / 4$ percent in a series of $25 \mathrm{bp}$ steps. The Riksbank has, as usual, published its projections for the policy rate, showing further rises of some $25 \mathrm{bp}$ at every monetary policy meeting over the next 12 months. The markets anticipate a broadly similar path. But with the real policy rate currently negative, the stance is nevertheless expected to remain accommodative in coming months, even as buoyant activity continues to close the remaining output gap.

34. In this context, measures of inflation expectations based on break-even rates for indexed government bonds, as well as those based on survey results, have broadly been anchored in the neighborhood of the target.

\section{The indicated further interest rate increases are appropriate}

35. An acceleration of the anticipated path would be required if assessments of output gap, wage settlement in the ongoing wage round, commodity prices, and house prices signal higher-than-expected inflationary pressures. 
36. But, on the other hand, the outlook for the krona will also remain central. If it continues to appreciate strongly, and continues to negate not only the second round but also the headline effects of rising global commodity price rises, a partial retreat even from the anticipated path will be appropriate.

\section{The monetary and exchange regimes remain appropriate}

37. The credibility of the free floating exchange rate arrangement and flexible inflation targeting regimes have been emphatically reinforced by their effectiveness through the recent global crisis.

38. Monetary policy should remain focused on the inflation target, helping to stabilize output and employment subject to that condition. Other objectives - including asset and house prices and financial stability - have not been explicit objectives of monetary policy. This remains appropriate, though there is need to strengthen coordination mechanisms with the other agencies responsible for these broader objectives (See Section IV). Such coordination could be essential to effective management of strains that may yet emerge in the housing market.

\section{Labor Market Issues}

Over the medium term, further efforts are needed to drive unemployment down to 5 percent on a sustained basis.

39. With signs of increased equilibrium unemployment and the long-term unemployed high, the challenge is to prevent cyclically high unemployment from becoming protracted and structural. Total employment is now back to pre-crisis levels. But some jobs lost during the crisis, especially in the manufacturing sector, are not likely to be replaced.

40. Crisis measures taken to address unemployment during the recession-including policies focused on lessening the fall in employment such as local government employment support and increasing the short term unemployed in labor market programs - will need to be gradually adjusted in light of new developments in the labor market. While business representatives emphasized the need for lower taxation and greater flexibility in regulations, particularly with respect to small and micro firms, the labor unions were more concerned with the quality of labor supply and longer term education and training initiatives. According to the OECD, further steps are needed to reduce the duality in employment protection legislation, further strengthen job-search incentives for the unemployed, and reform minimum wage structures.

41. Accordingly, policies should continue to reduce unemployment rates without lowering adult participation rates. This puts a premium on lowering labor market frictions, including impediments to matching. With various tax and labor market actions to this end already taken, the authorities project equilibrium unemployment at 5 percent in the 
medium-term ( $(24)$. However, achieving this projection will also require moderate wage increases in 2011-12, as well as the introduction of permanent concessionary wage determination arrangements for new entrants to the labor market.

Table. Labor Market Policies_-Structural Reforms

\begin{tabular}{|c|c|c|}
\hline Areas in labor market policies & OECD recommendations & Actions taken by the Swedish authorities \\
\hline $\begin{array}{l}\text { Reduce marginal taxes on labor } \\
\text { income }\end{array}$ & $\begin{array}{l}\text { Cut income taxes by raising the } \\
\text { threshold for the state income tax } \\
\text { or reduce its rate }\end{array}$ & $\begin{array}{l}\text { Lower threshold for state income tax was } \\
\text { raised in 2009; employer social security } \\
\text { contributions were reduced and in-work tax } \\
\text { credit expanded through } 2011 \text {. }\end{array}$ \\
\hline $\begin{array}{l}\text { Reform sickness and disability } \\
\text { benefit schemes }\end{array}$ & $\begin{array}{l}\text { Introduce a time limit on eligibility } \\
\text { for sickness benefits without } \\
\text { reassessment and ensure local } \\
\text { insurance offices fully implement } \\
\text { tightened rules. }\end{array}$ & $\begin{array}{l}\text { Tighten administration, time limits on } \\
\text { eligibility and measures for rehabilitation } \\
\text { have lowered sickness absence rates. }\end{array}$ \\
\hline $\begin{array}{l}\text { Reform employment protection } \\
\text { legislation }\end{array}$ & $\begin{array}{l}\text { Encourage regular employment } \\
\text { by widening the definition of fair } \\
\text { dismissal and lengthening the trial } \\
\text { period of regular contracts. }\end{array}$ & $\begin{array}{l}\text { No significant action on permanent contracts } \\
\text { but trial periods and duration of temporary } \\
\text { contracts were extended. }\end{array}$ \\
\hline
\end{tabular}

Sources: OECD, Swedish authorities.

\section{Financial Sector Stability}

Resilience to external tail risks requires decisive further steps to strengthen banking stability.

\section{The system is large, concentrated, and complex}

42. The financial system's assets are equivalent to 51/2 times GDP. Four major banking groups dominate the system (65 percent of market share) and have extensive cross-border operations and non-banking activities, with substantial reliance on wholesale funding markets (Figure 7).

\section{But its resilience has strengthened considerably}

43. Major banks have raised capital to well above the minimum regulatory requirements, with the common equity Tier 1 capital ratio ranging from 71/2-10 percent (11-15 percent with full Basel II rules, see text table) - comparable with their European and American peers. Their exposures to peripheral European economies are small, and their loan losses in the Baltics have fallen. The authorities indicate that each of these major banks has sufficient resources to meet the forthcoming Basel III capital requirements, including the capital conservation and counter-cyclical capital buffers. Meanwhile, the financial strength of the non bank financial sector, such as insurance and pensions, has also improved (Figure 8). 


\section{So exit from crisis intervention measures is underway}

44. The authorities have terminated most of their unconventional liquidity support measures. Of the remaining measures, government debt guarantee and recapitalization programs are expected to be terminated by end-June 2011. The Riksbank is reviewing the collateral policy framework, which was expanded during the crisis.

Summary of the Performance and Operation of Swedish Four Major Banks (In percent; unless otherwise indicated; end period)

\begin{tabular}{|c|c|c|c|c|c|c|c|c|c|c|c|c|c|c|c|c|c|}
\hline \multirow[b]{3}{*}{ Capital } & \multicolumn{4}{|c|}{ Nordea } & \multicolumn{4}{|c|}{ SEB } & \multicolumn{4}{|c|}{ Handelsbanken } & \multicolumn{4}{|c|}{ Swedbank } & \multirow{2}{*}{$\begin{array}{c}\begin{array}{c}\text { Median of } 44 \\
\text { European and } \\
\text { US banks }\end{array} \\
2010\end{array}$} \\
\hline & \multirow[t]{2}{*}{2008} & \multirow[t]{2}{*}{2009} & \multicolumn{2}{|c|}{$20101 Q 2011$} & \multirow[t]{2}{*}{2008} & \multirow[t]{2}{*}{2009} & \multicolumn{2}{|c|}{$20101 Q 2011$} & \multirow[t]{2}{*}{2008} & \multirow[t]{2}{*}{2009} & \multicolumn{2}{|c|}{$20101 Q 2011$} & \multirow[t]{2}{*}{2008} & \multirow[t]{2}{*}{2009} & \multicolumn{2}{|c|}{$20101 Q 2011$} & \\
\hline & & & & & & & & & & & & & & & & & \\
\hline Tier 1 common capital ratio to risk weighted assets $1 /$ & 6.7 & 9.3 & 8.9 & 9.1 & 7.1 & 10.7 & 10.9 & 11.4 & 5.9 & 7.5 & 7.7 & $\ldots$ & 7.0 & 9.2 & 10.1 & 10.4 & 9.8 \\
\hline Without the transition rules & & 10.3 & 10.3 & 10.7 & & 11.7 & 12.2 & 13.0 & & & & & & 12.0 & 13.9 & 14.9 & \\
\hline Tier 1 ratio to risk weighted assets $1 /$ & 7.4 & 10.2 & 9.8 & 10.0 & 8.4 & 12.8 & 12.8 & 13.2 & 7.0 & 9.1 & 9.2 & 9.3 & 8.1 & 10.4 & 11.0 & 11.2 & 12.2 \\
\hline Without the transition rules & & 11.4 & 11.4 & 11.7 & & 13.9 & 14.2 & 15.1 & & 14.2 & 16.5 & 17.2 & & 13.5 & 15.2 & 16.2 & \\
\hline Total capital to risk weighted assets 1 / & 9.5 & 11.9 & 11.5 & 11.4 & 10.6 & 13.5 & 12.4 & 12.7 & 10.6 & 12.9 & 11.6 & 11.0 & 11.2 & 13.5 & 13.3 & 13.0 & 15.6 \\
\hline Without the transition rules & & 13.4 & 13.4 & 13.5 & & 14.7 & 13.8 & 14.6 & & 20.2 & 20.9 & 20.4 & & 17.5 & 18.4 & 18.7 & $\ldots$ \\
\hline Leverage (Tier 1 as a percent of total assets) & 3.7 & 4.1 & 4.0 & $\ldots$ & 3.1 & 4.0 & 4.3 & $\ldots$ & 3.2 & 3.5 & 3.6 & $\ldots$ & 3.8 & 4.3 & 4.6 & $\ldots$ & $\ldots$ \\
\hline \multicolumn{18}{|l|}{ Assets } \\
\hline Gross impaired loans to total loans at amortized costs & 1.0 & 1.9 & 1.9 & $\ldots$ & 0.8 & 1.7 & 1.5 & $\ldots$ & 0.4 & 0.6 & 0.6 & $\ldots$ & 1.4 & 5.9 & 5.2 & $\ldots$ & 4.4 \\
\hline Net impaired loans to total loans at amortized costs & 0.5 & 0.9 & 0.9 & $\ldots$ & 0.5 & 0.9 & 0.7 & $\ldots$ & 0.2 & 0.3 & 0.3 & $\ldots$ & 1.0 & 2.9 & 2.5 & $\ldots$ & $\ldots$ \\
\hline \multicolumn{18}{|l|}{ Earnings and profitability } \\
\hline Return on assets & 0.6 & 0.5 & 0.5 & $\ldots$ & 0.4 & 0.0 & 0.3 & $\ldots$ & 0.6 & 0.5 & 0.5 & $\ldots$ & 0.7 & -0.6 & 0.4 & $\ldots$ & 0.7 \\
\hline Return on equity & 15.2 & 11.4 & 11.5 & $\ldots$ & 13.2 & 1.2 & 6.9 & $\ldots$ & 16.7 & 13.1 & 13.0 & $\ldots$ & 15.0 & -12.5 & 8.2 & $\ldots$ & 10.4 \\
\hline \multicolumn{18}{|l|}{ Liqui } \\
\hline Loans to customers deposits & 188.4 & 197.6 & 198.7 & $\ldots$ & 154.2 & 148.3 & 151.1 & $\ldots$ & 272.5 & 268.7 & 271.3 & $\ldots$ & 286.5 & 269.9 & 234.7 & $\ldots$ & 93.4 \\
\hline Deposits maturing less than 3 months to total deposits & 22.9 & 17.0 & 19.4 & $\ldots$ & 23.3 & 28.7 & 66.1 & $\ldots$ & 17.8 & 11.0 & 10.4 & $\ldots$ & 17.2 & 9.8 & 11.8 & $\ldots$ & ... \\
\hline \multicolumn{18}{|l|}{ Memorandum item: } \\
\hline Total assets in percent of GDP & 142.0 & 174.4 & 167.8 & $\ldots$ & 78.4 & 74.7 & 66.0 & $\ldots$ & 67.4 & 68.7 & 65.2 & $\ldots$ & 56.5 & 58.1 & 52.0 & $\ldots$ & $\ldots$ \\
\hline
\end{tabular}

Sources: Banks' annual reports; SNL database; and IMF staff estimates.

1/ With the transition rules. Under the Basel II capital adequacy rules, Swedish banks are allowed to substantially reduce capital adequacy requirements due to their large mortgage portfolios. However, currently, the FSA applies transitional regulations, allowing banks to reduce capital requirements only in stages.

\section{And regulations are being strengthened}

45. The authorities' intention is to go further and faster than the Basel III timeline. The details of the new requirements have yet to be worked out, but the FSA and MOF have already indicated that common equity Tier 1 capital requirements would be at least 10-12 percentage points in a few years. In this regard, with bank capital already strong relative to final Basel III goals, there is no need for the phase-in period, provided that banks maintain the current levels of their capital. In part, this provides additional insurance against the possibility of significant risk spillovers from the periphery to the euro area core.

46. In December 2010, the FSA adopted a new regulation on the governance of banks' liquidity risk management. A new comprehensive liquidity reporting framework will commence in July 2011, which includes quantitative liquidity risk measures by currency (comparable with a liquidity coverage ratio proposed by the Basel III). Thereafter, these measures will become subject to disclosure requirements, before being upgraded to binding prudential requirements, although specific timeline and detailed metrics have yet to be developed.

47. These regulatory reforms should be consistent with forthcoming EU-level decisions. However, Sweden's financial system is exposed to unique challenges-large, complex, and concentrated - and entailing "too large to fail" risks. It operates extensively across borders, 
but in this regard, even in the Scandinavian context, it has been difficult to establish a legally binding ex-ante cross-border bank resolution framework. Accordingly, effective discretionary supervision-including the active use of the Pillar II framework and the application of capital and liquidity surcharges to systemically important banks-will be an essential complement to the new Basel III and EU capital directives, especially if these international frameworks do not take account of each member country's idiosyncratic risk profile.

\section{Furthermore, three issues warrant close and ongoing assessment}

48. These are euro area tail risks, housing, and risks associated with the oversized financial system.

\section{The FSAP provides initial reassurance on credit risks, and warns on liquidity}

49. It finds Sweden's financial system is generally sound. Its credit assessment is not predicated on euro area tail risks, but rather on an adverse macroeconomic scenarioprolonged low growth and a domestic housing market crash. In this context, it finds that all major banks would maintain 7 percent common equity Tier 1 capital ratios required under Basel III.

50. On the other hand, the liquidity assessment, even without considering directly the feedback loops in housing, finds in stress scenarios that banks could face difficulties given their reliance on wholesale funding (Box 4).

\section{An even broader perspective provides some further reassurance}

51. Sweden appears well-situated even in a euro area tail risk scenario. Direct exposures to peripheral European economies are minimal. And indicators of overall exposures of Swedish institutions to peripheral risks - albeit excluding the possibility of significant spillover to the euro area core-show reduced market concerns about Swedish institutions since mid-2009, even though the euro area strains have deepened in various ways since then (text figure). Such reassuring assessments can turn suddenly, however, if markets reevaluate the risks of major strains spilling over to the core.
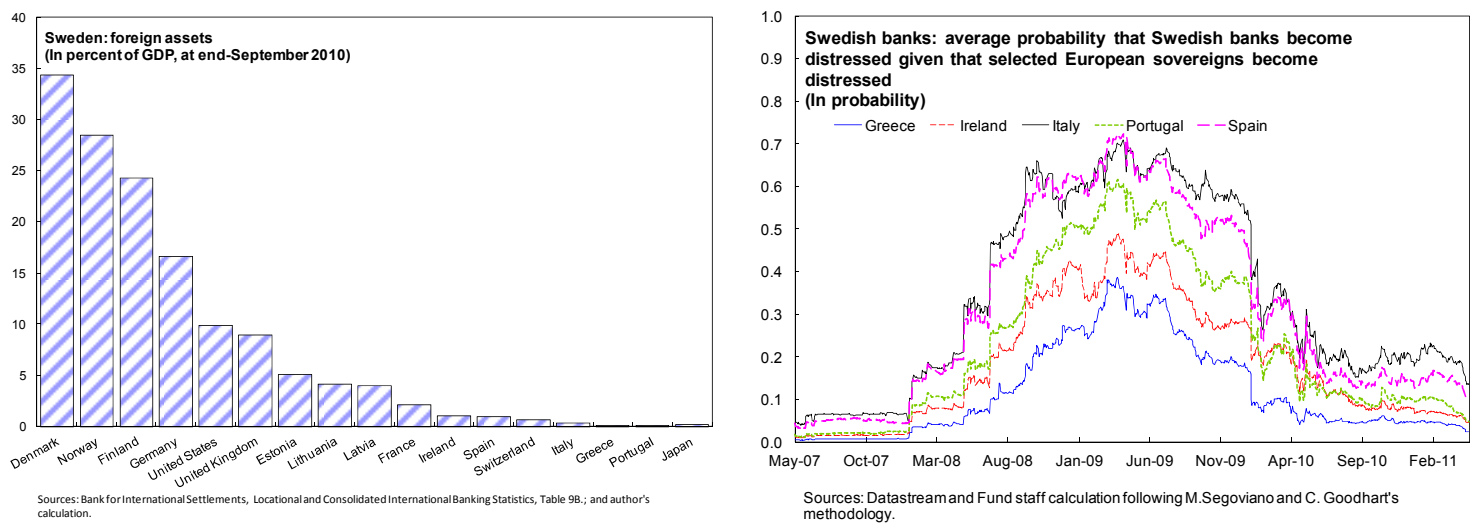


\section{Box 4. Liquidity Risk}

By 2008, the share of banks' funding through non-deposit sources reached nearly half of their lending, in excess even of the relatively high median for European peers. Meanwhile, Swedish banks aggressively expanded cross border activities with substantial Euro exposure, including in the Baltics.

Several Swedish banks experienced difficulty in rolling over their debt obligations, particularly after the collapse of Lehman Brothers in September 2008. This was reflected in a sharp increase in the risk premium in the Swedish interbank markets. In response, the authorities implemented unprecedented liquidity easing measures.

Currently, the authorities are tightening the regulatory framework on liquidity risk management. In December 2010, the FSA adopted a new regulation on "Management of Liquidity Risks in Credit Institutions and Investment Firms" (FFFS 2010:7), which requires financial institutions to establish a proper governance framework for liquidity

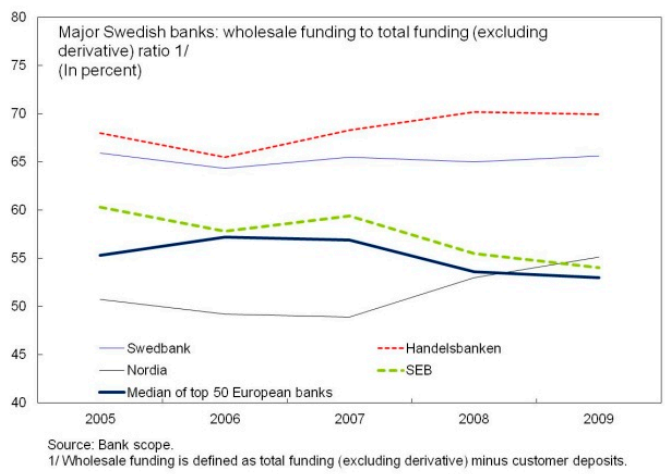
risk management. The FSA is also introducing a new comprehensive liquidity reporting framework in July 2011, which covers detailed information on liquidity reserves, cash flows, funding, and derivatives by currency, and banks will be required to report the Liquidity Coverage Ratio (LCR) by major currencies (Swedish kroner, euro, and U.S. dollar) in line with the Basel III agreement. Further options remain under consideration, to go further and faster than the Basel III requirements.

Already, these moves have induced a behavioral change in banks: the Riksbank's structural liquidity measure-an indicator similar to Basel III net stable funding ratioimproved for most major banks, although Swedish banks are still behind other European banks.

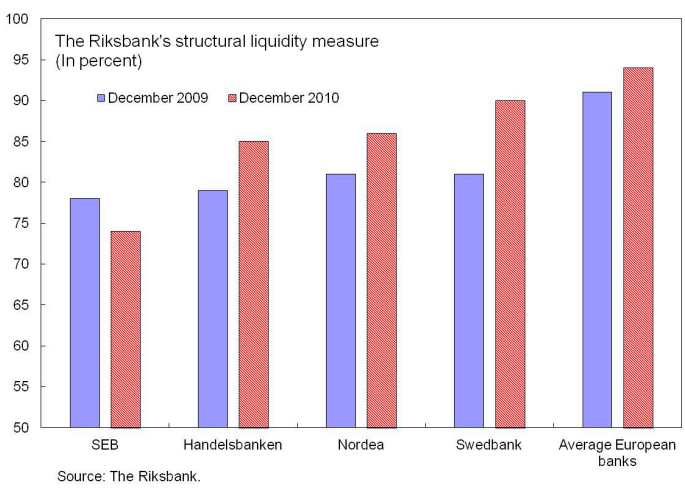


52. On the housing side, the concern is if a shock to house prices was to impair confidence in the covered bond market (see Box 5). High collateral margins and routine cleansing of the pool establishes a high degree of resilience against such risks. And, as illustrated during the recent global crisis, the authorities possess and use tools to respond even if confidence nevertheless falters. In particular, when the private market in covered bonds effectively shut down after the Fall of 2008, the Riksbank accepted a wider range of covered bonds as collateral and the NDO purchased covered bonds in exchange of treasury securities. Thus, the momentum of credit supply to households was largely undisturbed, despite the shock. A sustained drop in house prices of some 40 percent would be required to reduce the value of collateral pools below the face value of the outstanding bonds.

53. The household debt-to-income ratio has more than doubled since the mid-1990s, with mortgages explaining most of this increase, in part reflecting the absence of a buy-to-let market. Moreover, available data to 2007 confirm that high net worth households account for the bulk of Swedish household debt. Given the large debt-to-income and elevated house prices, it would be important to confirm that the debt service patterns by more recent generations of house buyers continue to adhere to the standards maintained by their forebears. In this context, additional data of credit quality, including historical data on mortgage service by vintage of house purchase, as well as bank lending activities to households, would need to be collected and monitored. These data would help further strengthen the robustness of stress tests and supervisory assessment of capital risk weights.

54. On the other hand, if significant financial stability or consumer risks are identified, further actions to cool housing markets would be needed to ensure credit quality. Lower mortgage interest deductions and loan-to-value ratios, introduction of debt-to-income regulations, and adjustments to risk weight assets would be amongst the options to be considered in this context.

55. On financial system size, the main risks are being addressed indirectly. In particular, the proposed strengthening of liquidity regulations will likely curb the growth of the banking sector by limiting scope for the sector to free-ride on the public liquidity backstop. In these circumstances, and with credit risks also contained - as the global crisis revealed and the FSAP stress tests reiterate-Sweden's strong fiscal credentials enable it to sustain the associated risks, setting Sweden apart from others with similarly oversized financial sectors. However, ongoing maintenance of effective regulatory and supervisory oversight of these risks will be absolutely essential.

\section{This broader perspective underscores the main FSAP recommendations}

56. First, the FSA's budgetary resources should be raised further to ensure its ongoing effectiveness - not least given the size of the financial sector it supervises. There is also need to focus its mandate more closely on core stability rather than broader social concerns. 


\section{Box 5. The Swedish Covered Bond Market}

The outstanding stock of covered bonds stands at over 50 percent of GDP, up from below 20 percent of GDP in the mid-2000s. Investor appetite improved since the enactment of the 2004 Swedish Covered Bond Act, under which investors are secured by "double recourse:" they have recourse to both the collateral pool backing the specific covered bond program and to the estate of the bank on its default. Loans cannot exceed

fixed percentages of collateral value $-75,70$, and 60 percent for residential, agricultural and

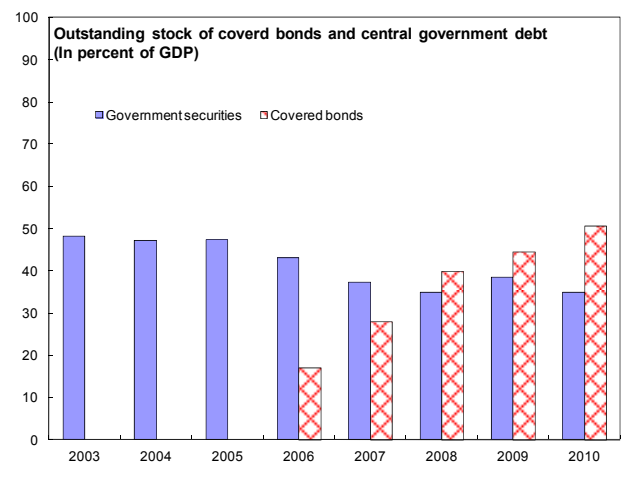
commercial mortgages respectively — with collateral frequently revalued, and all impaired mortgages are "cleansed" from the pools frequently, and are replaced by unimpaired loans.

Swedish banks' reliance on covered bond funding for housing finance has also increased rapidly. The amount of covered bond issuance as a share of total mortgage lending rose has doubled to 80 percent since 2006. Also, funding costs of covered bonds are lower than those of alternative means, such as senior debt issuance, contributing to lower mortgage interest rates, thereby stimulating mortgage demand.

Despite the "double recourse" mechanism, Swedish covered bonds markets were adversely affected by the global crisis. In late 2008-early 2009, covered bond spreads over treasury securities yields significantly widened, and demand for covered bonds, in both primary and secondary markets, fell sharply. The decline in investor appetite was particularly evident in euro markets. In response, the Riksbank accepted a wider range of covered bonds as collateral, the NDO issued treasury securities, beyond its funding needs, and invested the funds in covered bonds to support covered bond markets, and the government introduced the bank debt guarantee

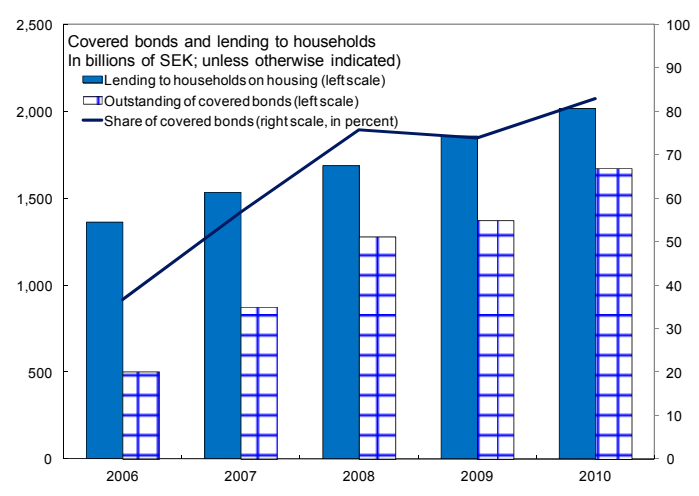
program.

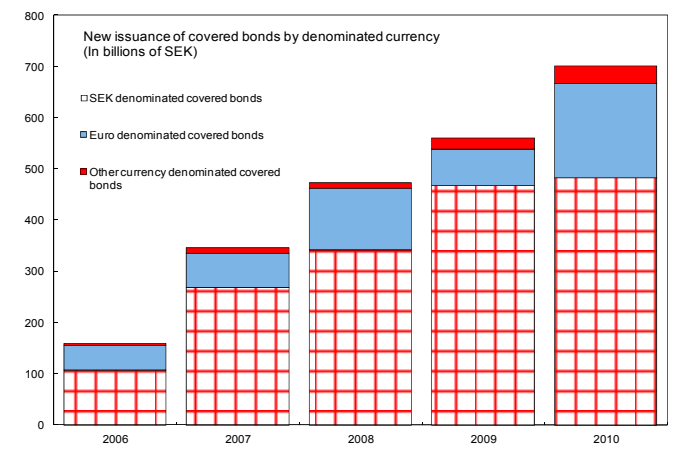

Accordingly, covered bonds - and their originators, banks - would not be immune to shocks. For example, a fall in house prices could result in a decline in investor appetite for covered bonds, leading to higher interest rates or even refinancing risks, as occurred in some peripheral European economies. Furthermore, although covered bonds are protected from liquidity risks due to asset and liability matching requirements, this merely means that final mortgage borrowers bear liquidity risks. Thus banks would most likely shoulder indirect risks if markets are hit by shocks. 
57. Second, there is need to enhance mechanisms to coordinate the various authorities with mandates concerning financial stability. A Systemic Financial Stability Council (SFSC) with representation from the Riksbank, FSA, NDO, and MOF-could serve this purpose, coordinating both preemptive and reactive stability policies. Its mandate would need to specify the limits of its powers to direct its members' actions - particularly regarding those which are formally independent and in regard to confidential information - as well as its internal decision-making mechanisms. The Committee on the Review of the Regulatory Framework has been set up, with a view to presenting its recommendations on regulatory reform to the government in August 2012.

58. However, given external vulnerabilities, action should not await completion of the Committee's recommendations. The principles of the Riksbank, FSA, NDO, and MOF could commence immediately routine quarterly meetings to review macroprudential risks and coordinate policy settings. Initial topics to be examined include prudential risks pertaining to housing, the risks arising from broader euro area strains, and related policy options, such as the appropriate level of international reserves. ${ }^{3}$

59. A review of the stability fund framework may have merits. Sweden is among those economies that introduced a financial stability fund and fee during the crisis. There are good grounds to review options to merge the stability and deposit insurance funds and to introduce risk-based fees.

60. Finally, a special bank resolution framework — a long standing agenda — should be introduced.

61. Sweden has made significant progress in addressing deficiencies in its AML/CFT framework identified by the Financial Action Task Force (FATF) in 2006. In particular, the FSA's regulations have been strengthened, including in areas of customer due diligence and reporting of suspicious transactions and compliance. As a result, the FATF has removed Sweden from the list of its regular follow up members in October 2010.

\section{The Authorities' Views}

62. Sweden has recovered decisively from the global financial crisis, reflecting strong policies domestically and globally, as well as the legacy of many years of decisive structural reforms. In this context, the stance of policies - especially on the monetary side - should, provided developments turn out as now expected, continue to tighten in measured fashion, and buffers should continue to be reinforced on the fiscal and financial sector sides to address external risks. In this context, continued moderation of wage growth in the negotiation round commencing in the Fall is essential to sustaining strong overall performance and job growth.

\footnotetext{
${ }^{3}$ See Attachment III.
} 
Alongside, there is need for special arrangements to address long term unemployment and labor market entrants issues. The staff agree with these central assessments.

63. Notwithstanding that overall consensus, there are some differences in nuance and emphasis.

64. First, on the current conjuncture, and according to the Riksbank's estimates, the output gap narrowed to roughly negative $1 / 2$ percent in 2011 - closer to balance than Ministry of Finance and staff estimates. The latter suggest an output gap of up to negative 2 percent in 2011. Differences reflect, among other matters, assumptions about potential, with the Riksbank taking the view that growth in productivity has slowed down compared to the strong growth between the mid-90s and 2006, yielding potential GDP growth at just above 2 percent. This compares with long run estimates of $2 \frac{1}{2}$ percent for staff. In addition, the Riksbank and staff project, at present, the long run equilibrium rate of unemployment on currently announced policies to be around 1 percentage point higher than anticipated by the Ministry of Finance.

65. Second, while the authorities expect further dampening of house prices as policy rates rise, they emphasized that this was unlikely to be destabilizing to the macroeconomic outlook or to pose risks to financial stability, given that house prices were broadly in line with fundamentals. Nevertheless, they acknowledged risks posed by buoyant housing and household indebtedness, and noted that prices had begun to dampen following recent new loan-to-value regulations and policy interest rate increases. Further prudential measures would be taken in the event of a resurgence of house prices to head off risks.

66. Third, in the context of agreement with staff that the fiscal position was strong, and that buffers should be strengthened further, the authorities' estimate of the underlying fiscal position differs from staff. The difference reflects estimates of the size of the output gap and the more aggregated methodology to adjust for cyclical components used by the authorities. This reflects the authorities' use of the OECD aggregate elasticity of 0.55 , in contrast to the staff's disaggregated adjustments using both output and employment gaps. Specifically, the fiscal authorities' estimates of the cyclically adjusted balance in 2009-10 are 3 and 1.8 percent of GDP, while staff's estimates are 1.3 and 1.4 percent of GDP.

67. Fourth, the staff agree with the authorities on the scope for further fiscal initiatives in 2012 and beyond, and that these should focus on improving the functioning and flexibility of the labor market. However, the authorities are proposing as a further option the reduction of the rate of VAT on restaurants on the basis that this will boost employment in that sector.

68. Fifth, with regard to the Fiscal Policy Council, the authorities consider that its mandate has recently been sufficiently narrowed towards focus on medium-term sustainability. And they suggest that in the Swedish context, its watchdog role and independence are well anchored by continuing the arrangement whereby it reports to the government. 
69. On the financial side, the authorities assessed stability as strong, but, supported by staff in light of the given external risks, initiatives have been taken to sustain buffers or to raise buffers further. In that context, the authorities expressed considerable concern that the EU-level negotiations might constrain the ability of member states to differentiate regulatory requirements to take account of idiosyncratic vulnerabilities - such as the size of the sectorand noted the consequent risks. In addition, they will consider the feasibility of collecting data by vintage of house purchase, but do not expect it to change their overall assessment of robustness.

70. As part of efforts to strengthen buffers in the financial sector, the authorities also want to be able to impose stronger liquidity requirements than Basel III.

\section{Staff Appraisal}

71. Sweden's exit from the global crisis has been uniquely successful compared to others in the European Union, reflecting strong global and domestic policies.

72. In 2010, output rose 5 $\frac{1}{2}$ percent and this momentum has been maintained into 2011 . Unemployment is down from its mid-crisis peak, and core inflation has remained close to target throughout. Financial sector strains have been contained, bank capital and liquidity have strengthened, and most emergency stabilization measures have been withdrawn. With over-observance of the fiscal rules, the government budget is now heading decisively back to its customary surplus and public debt remains some 40 percent of GDP and falling. Alongside, a cautious monetary tightening cycle is under way, together with macrofinancial measures to cool housing. And the krona remains competitive.

73. The laggards in recovery are long-term and youth unemployment, and fixed investment - which, although rising again, is still below 2006-08 levels relative to output. And there are concerns that although house prices have recently dipped, they may still be overvalued.

74. The challenge now is to sustain this success. This will require continued close coordination of policies.

75. To this end, the underlying fiscal stance should remain unchanged in 2011-12. Given the remaining output gap and with the structural balance in 2010 considerably stronger than required to meet those medium-term targets, there is a case to maintain a neutral stance in 2011-12, notwithstanding buoyant growth. The 2011 budget delivers this while building buffers by increasing the "safety margins" between the spending ceilings and appropriated spending, and by postponing planned tax reductions to 2012 .

76. This underlying budget stance should remain for 2012, and for the same reasons. Only in the unlikely event that significant sustained krona overvaluation occurs would there be need to shift the underlying stance for 2012 to a tightening. 
77. With the underlying fiscal stance unchanged, a mix of expenditure and tax initiatives will be feasible in 2012. Of the latter under consideration, emphasis on the steps to strengthen labor market performance — expansion of the earned income tax credit—is recommended.

78. Alongside, the Fiscal Policy Council remains a key element of the fiscal framework. In formal recognition of its watchdog role, it could be made directly accountable to Parliament, its resourcing should be enhanced, and, building on the recent review by the authorities, its mandate could be even more narrowly focused on medium-term fiscal sustainability.

79. The monetary stance should continue to tighten in 2011 as indicated. If assessments of the output gap, wage developments, and commodity and house prices signal stronger inflationary pressures, the policy rate should be raised more rapidly than indicated. But if the krona continues to appreciate strongly, then the path for the policy rate rises may need to be delayed to offset its disinflationary effects.

80. The free floating exchange rate regime Sweden maintains has clearly served well during the global crisis, and appropriately will be retained.

81. Within this free floating framework, while international reserves are sufficient to address risks, given euro area strains, this judgment of reserve adequacy should remain under active review in view of the financial sector's exposures.

82. Sustained falls in unemployment remain a priority. In this context, moderate settlements in the 2011-12 wage round - in the neighborhood of 3 percent - will be key. As part of this, significant permanent concessionary arrangements for labor market entrants in the negotiated wage agreements would be highly desirable.

83. External fragilities underscore need for further progress on financial stability. The FSAP assessment provided initial reassurance on credit risks. But historical data on mortgage service by vintage of house purchase should be collected to confirm this. Such data could also inform adjustments to capital risk weights and the specification of technical parameters used in stress tests. But, if significant financial stability or consumer risks are identified, further macroprudential measures will be needed to ensure that these credit risks do not deteriorate.

84. Furthermore, given the unique characteristics and risks of the Swedish financial system - including risks that euro area periphery strains spillover to the core- the authorities' intention to go further and faster than Basel III regulations are appropriate. With bank capital already strong relative to ultimate Basel III goals, there is no need for the phasein period. Alongside, following the recent strengthening of monitoring of liquidity, the early introduction of strong liquidity regulations, taking particular account of risks in foreign currencies is encouraged. Systemic capital and liquidity surcharges to internalize risks posed 
to the system will also be appropriate. Effects on credit growth from all these actions should be factored in to decisions on the policy rate.

85. The FSAP also recommended a number of institutional reforms: reviewing options to merge the stability and deposit insurance funds; introducing a special bank resolution framework; and establishing of all key macroprudential institutions to strengthen coordination. The establishment of the Committee on the Review of the Regulatory Framework set up to consider such institutional arrangements is welcome.

86. And the FSAP confirmed long-standing calls from the IMF to increase further the resources allocated to banking supervision. Given the unique characteristics of the financial system, effective discretionary supervision will be an essential complement to the new regulatory frameworks coming into effect under Basel III and European auspices, especially if these international frameworks constrain country-level discretion above floors.

87. Sweden should remain on the standard 12-month consultation cycle. 
Table 1. Sweden: Selected Economic and Social Indicators, 2005-12

\begin{tabular}{|c|c|c|c|c|c|c|c|c|}
\hline & \multirow[b]{2}{*}{2005} & \multirow[b]{2}{*}{2006} & \multirow[b]{2}{*}{2007} & \multirow[b]{2}{*}{2008} & \multirow[b]{2}{*}{2009} & \multirow[b]{2}{*}{2010} & \multicolumn{2}{|c|}{ Projections } \\
\hline & & & & & & & 2011 & 2012 \\
\hline \multicolumn{9}{|l|}{ Real economy (in percent change) } \\
\hline Real GDP & 3.2 & 4.3 & 3.3 & -0.6 & -5.3 & 5.5 & 4.4 & 3.8 \\
\hline Domestic Demand & 3.0 & 3.9 & 4.7 & 0.0 & -4.9 & 6.1 & 2.9 & 3.3 \\
\hline CPI inflation & 0.8 & 1.5 & 1.7 & 3.3 & 2.0 & 1.9 & 3.0 & 2.5 \\
\hline Unemployment rate (in percent) & 7.6 & 7.0 & 6.1 & 6.2 & 8.3 & 8.4 & 7.4 & 6.6 \\
\hline Gross national saving (percent of GDP) & 24.5 & 27.2 & 29.6 & 28.9 & 23.4 & 25.0 & 26.0 & 27.0 \\
\hline Gross domestic investment (percent of GDP) & 17.7 & 18.7 & 20.3 & 20.2 & 16.3 & 18.5 & 20.0 & 21.4 \\
\hline Output Gap (as a percent of potential) & 4.2 & 5.6 & 5.4 & 1.5 & -5.9 & -3.1 & -1.6 & -0.9 \\
\hline \multicolumn{9}{|l|}{ Public finance (in percent of GDP) } \\
\hline Total Revenues & 53.8 & 53.0 & 52.5 & 51.9 & 52.1 & 50.7 & 49.3 & 48.6 \\
\hline Total Expenditures & 51.8 & 50.8 & 46.1 & 46.6 & 49.7 & 47.8 & 45.2 & 44.2 \\
\hline Overall balance & 1.9 & 2.2 & 3.6 & 2.2 & -0.9 & -0.3 & 0.8 & 1.3 \\
\hline Structural balance (as a percent of potential GDP) ${ }^{1 /}$ & 3.0 & 1.9 & 1.0 & 0.9 & 1.3 & 1.4 & 1.3 & 1.2 \\
\hline General government gross debt, official statistics & 50.4 & 45.3 & 40.2 & 38.8 & 42.8 & 39.8 & 36.1 & 32.7 \\
\hline Gross public debt, Maastricht criterion & 50.2 & 45.0 & 40.0 & 38.3 & 42.1 & $\ldots$ & $\ldots$ & $\ldots$ \\
\hline \multicolumn{9}{|l|}{ Money and credit (12-month, percent change) } \\
\hline M1 & 9.4 & 11.1 & 9.9 & 4.9 & 8.0 & 7.1 & $\ldots$ & $\ldots$ \\
\hline M3 & 7.5 & 10.6 & 12.5 & 10.4 & 8.2 & 4.5 & $\ldots$ & $\ldots$ \\
\hline Credit to non-bank public & 10.8 & 11.2 & 14.3 & 7.7 & $\ldots$ & $\ldots$ & $\cdots$ & $\ldots$ \\
\hline \multicolumn{9}{|l|}{ Interest rates (year average) } \\
\hline Repo rate & 1.5 & 3.0 & 4.0 & 2.0 & 0.3 & 1.3 & $\ldots$ & $\ldots$ \\
\hline Three-month treasury bill rate & 1.7 & 2.3 & 3.5 & 3.8 & 0.4 & 0.5 & $\ldots$ & $\ldots$ \\
\hline Ten-year government bond yield & 3.4 & 3.7 & 4.2 & 3.9 & 3.3 & 2.9 & $\ldots$ & $\ldots$ \\
\hline \multicolumn{9}{|l|}{ Balance of payments (in percent of GDP) } \\
\hline Current account & 6.8 & 8.4 & 9.2 & 8.7 & 7.0 & 6.3 & 6.0 & 5.7 \\
\hline Trade balance & 7.2 & 7.8 & 7.2 & 6.6 & 6.6 & 6.0 & 5.8 & 5.4 \\
\hline Foreign Direct Investment, net & -4.5 & 0.7 & -2.3 & 1.2 & -5.2 & -2.1 & -2.1 & -2.1 \\
\hline International reserves (in billions of US dollars) & 26.4 & 26.0 & 29.7 & 35.4 & 44.2 & 46.6 & 53.9 & 55.8 \\
\hline Reserve cover (months of imports of goods and services) & 2.1 & 2.0 & 1.8 & 1.7 & 3.0 & 3.3 & 2.9 & 2.9 \\
\hline \multicolumn{9}{|l|}{ Exchange rate (period average, unless otherwise stated) } \\
\hline Exchange rate regime & \multicolumn{8}{|c|}{ Free Floating Exchange Rate } \\
\hline Skr per U.S. dollar (June 1, 2011) & \multicolumn{8}{|c|}{6.15} \\
\hline Nominal effective rate $(2000=100)$ & 99.2 & 99.5 & 101.3 & 99.5 & 90.7 & 97.8 & $\ldots$ & $\ldots$ \\
\hline Real effective rate $(2000=100)^{2 \prime}$ & 84.4 & 80.2 & 84.2 & 84.4 & 80.0 & 81.8 & $\ldots$ & $\ldots$ \\
\hline \multicolumn{9}{|l|}{ Fund Position (April 30, 2011) } \\
\hline Holdings of currency (in percent of quota) & & & & 74.51 & & & & \\
\hline Holdings of SDRs (in percent of allocation) & & & & 100.74 & & & & \\
\hline Quota (in millions of SDRs) & & & & 2395.50 & & & & \\
\hline \multicolumn{9}{|c|}{$\begin{array}{l}\text { Social Indicators (reference year) } \\
\text { GDP per capita (in current PPP US dollars, 2009): } 35,805 \text {; Income Distribution (ratio of income received by top } \\
\text { and bottom quintiles, 2005): } 3.3 \text {; Life expectancy at birth (2009): } 79.3 \text { (males) and } 83.3 \text { (female); Automobile ownership } \\
\text { (2004): } 456 \text { per thousand; CO2 Emissions (tonnes per capita, 2007): } 5.4 \text {; Population Density (inhabitants per sq. km., } \\
\text { 2008): 22; Poverty Rate (share of the population below the established risk-of-poverty line, 2005): } 9 \% \text {. }\end{array}$} \\
\hline
\end{tabular}

1/ Staff Estimates

2/ Based on relative unit labor costs in manufacturing.

Sources: Statistics Sweden; Riksbank; Ministry of Finance; Datastream; INS; and IMF staff estimates. 
Table 2. Sweden: Financial System Structure, 2002-10

\begin{tabular}{|c|c|c|c|c|c|c|c|c|c|c|c|c|c|c|c|c|c|}
\hline & \multicolumn{4}{|c|}{2002} & \multicolumn{4}{|c|}{2007} & \multicolumn{4}{|c|}{2009} & \multicolumn{5}{|c|}{2010} \\
\hline & $\begin{array}{l}\begin{array}{l}\text { Number of } \\
\text { institutions }\end{array} \\
\end{array}$ & $\begin{array}{c}\text { Total } \\
\text { assets (in } \\
\text { millions of } \\
\text { SEK) } \\
\end{array}$ & $\begin{array}{l}\text { Percent of } \\
\text { total } \\
\text { assets }\end{array}$ & $\begin{array}{l}\text { Percent of } \\
\text { GDP }\end{array}$ & $\begin{array}{l}\text { Number of } \\
\text { institutions }\end{array}$ & $\begin{array}{l}\text { Total assets } \\
\text { (in millions } \\
\text { of SEK) }\end{array}$ & $\begin{array}{l}\text { Percent of } \\
\text { total } \\
\text { assets }\end{array}$ & $\begin{array}{l}\text { Percent of } \\
\text { GDP }\end{array}$ & $\begin{array}{l}\text { Number of } \\
\text { institutions }\end{array}$ & $\begin{array}{l}\text { Total assets } \\
\text { (in millions } \\
\text { of SEK) }\end{array}$ & $\begin{array}{l}\text { Percent of } \\
\text { total } \\
\text { assets }\end{array}$ & $\begin{array}{l}\text { Percent of } \\
\text { GDP }\end{array}$ & $\begin{array}{l}\text { Number of } \\
\text { institutions }\end{array}$ & $\begin{array}{l}\text { Number of } \\
\text { branches }\end{array}$ & $\begin{array}{l}\text { Total assets } \\
\text { (in millions } \\
\text { of SEK) }\end{array}$ & $\begin{array}{l}\text { Percent of } \\
\text { total } \\
\text { assets }\end{array}$ & $\begin{array}{l}\text { Percent of } \\
\text { GDP }\end{array}$ \\
\hline \multicolumn{18}{|l|}{ Four Major Banks, consolidated } \\
\hline Nordea & 1 & $2,284,713$ & 24.9 & 93.5 & 1 & $3,679,361$ & 24.9 & 117.7 & 1 & $5,212,530$ & 30.3 & 162.7 & 1 & 8 & $3 \quad 5,491,917$ & 30.7 & 171.4 \\
\hline Handelsbanken & 1 & $1,277,514$ & 13.9 & 52.3 & 1 & $1,859,382$ & 12.6 & 59.5 & 1 & $2,122,843$ & 12.3 & 66.2 & 1 & 26 & $2,188,032$ & 12.2 & 68.3 \\
\hline S.E.B & 1 & $1,241,112$ & 13.5 & 50.8 & 1 & $2,344,462$ & 15.9 & 75.0 & 1 & $2,308,227$ & 13.4 & 72.0 & 1 & 16 & $2,253,779$ & 12.6 & 70.3 \\
\hline Swedbank & 1 & 957,503 & 10.4 & 39.2 & 1 & $1,607,984$ & 10.9 & 51.4 & & $1,794,687$ & 10.4 & 56.0 & 1 & 6 & $1,845,932$ & 10.3 & 57.6 \\
\hline Total Top Four Banks & & $5,760,842$ & 62.7 & 235.7 & 4 & $9,491,189$ & 64.3 & 303.6 & & $11,438,287$ & 66.5 & 357.0 & 4 & 56 & $11,779,660$ & 65.9 & 367.6 \\
\hline \multicolumn{18}{|l|}{ Four major banks in Sweden 1/ } \\
\hline Banks & 4 & $2,780,140$ & 30.3 & 113.8 & 4 & $6,079,039$ & 41.2 & 194.5 & 4 & $7,040,183$ & 40.9 & 219.7 & 4 & 39 & $7,110,540$ & 39.8 & 221.9 \\
\hline Insurance companies & 8 & 297,262 & 3.2 & 12.2 & 9 & 529,765 & 3.6 & 16.9 & 8 & 509,691 & 3.0 & 15.9 & 8 & 2 & 531,718 & 3.0 & 16.6 \\
\hline Mortgage credit institutions & 3 & 945,606 & 10.3 & 38.7 & 3 & $1,497,436$ & 10.1 & 47.9 & 3 & $1,899,919$ & 11.0 & 59.3 & 3 & 2 & $1,983,218$ & 11.1 & 61.9 \\
\hline Securities firms & 3 & 1,181 & 0.0 & 0.0 & 3 & 20,339 & 0.1 & 0.7 & 3 & 30,242 & 0.2 & 0.9 & 3 & 4 & 9,418 & 0.1 & 0.3 \\
\hline Other credit market companies & 5 & 107,520 & 1.2 & 4.4 & 9 & 195,326 & 1.3 & 6.2 & 8 & 235,297 & 1.4 & 7.3 & 8 & 11 & 222,816 & 1.2 & 7.0 \\
\hline Top four banks in Sweden & 23 & $4,131,709$ & 45.0 & 169.1 & 28 & $8,321,905$ & 56.4 & 266.2 & 26 & $9,715,332$ & 56.5 & 303.2 & 26 & 58 & $39,857,710$ & 55.2 & 307.6 \\
\hline \multirow{2}{*}{\multicolumn{18}{|c|}{$\begin{array}{l}\text { Other Banks in Sweden } \\
\text { Of which: }\end{array}$}} \\
\hline & & & & & & & & & & & & & & & & & \\
\hline Banks & 27 & 153,122 & 1.7 & 6.3 & 24 & 404,711 & 2.7 & 12.9 & 30 & 481,797 & 2.8 & 15.0 & 30 & 18 & 509,316 & 2.9 & 15.9 \\
\hline Savings banks & 77 & 95,689 & 1.0 & 3.9 & 65 & 146,450 & 1.0 & 4.7 & 53 & 164,177 & 1.0 & 5.1 & 52 & 0 & 170,670 & 1.0 & 5.3 \\
\hline Mortgage credit institutions & 11 & 459,923 & 5.0 & 18.8 & 4 & 315,522 & 2.1 & 10.1 & 4 & 436,302 & 2.5 & 13.6 & 4 & 0 & 495,149 & 2.8 & 15.5 \\
\hline Member bank & 2 & 878 & 0.0 & 0.0 & 2 & 1,246 & 0.0 & 0.0 & 2 & 1,521 & 0.0 & 0.0 & 2 & 0 & 1,583 & 0.0 & 0.0 \\
\hline Other credit market companies & 63 & 368,080 & 4.0 & 15.1 & 45 & 587,840 & 4.0 & 18.8 & 43 & 790,385 & 4.6 & 24.7 & 41 & 30 & 769,463 & 4.3 & 24.0 \\
\hline Total other banks in Sweden & 180 & $1,077,692$ & 11.7 & 44.1 & 140 & $1,455,769$ & 9.9 & 59.6 & 132 & $1,874,182$ & 10.9 & 76.7 & 129 & 48 & $31,946,181$ & 10.9 & 79.6 \\
\hline \multicolumn{18}{|l|}{ Nonbank credit institutions } \\
\hline Insurance companies & 165 & $1,654,032$ & 18.0 & 67.7 & 247 & $2,226,389$ & 15.1 & 71.2 & 253 & $2,351,945$ & 13.7 & 73.4 & 254 & 44 & $\quad 2,487,278$ & 13.9 & 77.6 \\
\hline Life insurance & 38 & $1,289,888$ & 14.0 & 52.8 & 45 & $1,678,359$ & 11.4 & 53.7 & 43 & $1,782,371$ & 10.4 & 55.6 & 44 & 6 & $1,924,131$ & 10.8 & 60.0 \\
\hline Nonlife insurance $2 /$ & 127 & 364,144 & 4.0 & 14.9 & 202 & 548,030 & 3.7 & 17.5 & 210 & 569,574 & 3.3 & 17.8 & 210 & 38 & $3 \quad 563,147$ & 3.2 & 17.6 \\
\hline Pension funds & 12 & 80,251 & 0.9 & 3.3 & 15 & 126,767 & 0.9 & 4.1 & 14 & 105,567 & 0.6 & 3.3 & 13 & 0 & 119,087 & 0.7 & 3.7 \\
\hline Mutual funds $3 /$ & 615 & 565,102 & 6.2 & 23.1 & 793 & $1,416,210$ & 9.6 & 45.3 & 849 & $1,393,337$ & 8.1 & 43.5 & 878 & 0 & $1,511,564$ & 8.5 & 47.2 \\
\hline \multicolumn{18}{|l|}{ Other nonbank credit institutions } \\
\hline Asset management firms & 67 & 3,398 & 0.0 & 0.1 & 82 & 8,160 & 0.1 & 0.3 & 82 & 7,346 & 0.0 & 0.2 & 80 & 0 & 7,662 & 0.0 & 0.2 \\
\hline Securities firms & 100 & 45,500 & 0.5 & 1.9 & 126 & 40,149 & 0.3 & 1.3 & 132 & 28,895 & 0.2 & 0.9 & 135 & 7 & 14,432 & 0.1 & 0.5 \\
\hline Total financial system & 1,143 & $9,186,817$ & 100.0 & 375.9 & 1,407 & $14,764,633$ & 100.0 & 472.3 & 1,466 & $17,199,559$ & 100.0 & 536.8 & 1,493 & 155 & $17,865,864$ & 100.0 & 557.6 \\
\hline of which: Total banking sector $4 /$ & & $6,838,534$ & 74.4 & 279.9 & & $10,946,958$ & 74.1 & 350.2 & & $13,312,469$ & 77.4 & 415.5 & & & $13,725,841$ & 76.8 & 428.4 \\
\hline \multicolumn{18}{|l|}{ Memorundam item: } \\
\hline Foreign bank branches in Sweden & $\ldots$ & $\ldots$ & & $\ldots$ & 25 & 753,482 & 5.1 & 24.1 & 24 & 686,265 & 4.0 & 21.4 & 25 & & 789,194 & 4.4 & 24.6 \\
\hline Swedish bank branches in abroad & $\ldots$ & $\ldots$ & $\ldots$ & $\ldots$ & 52 & $1,324,288$ & 9.0 & 42.4 & 55 & $1,411,402$ & 8.2 & 44.0 & 57 & & $1,473,498$ & 8.2 & 46.0 \\
\hline Employees in the financial system & $\ldots$ & $\ldots$ & $\ldots$ & & & & & 76,508 & & & & 82,991 & & & & & \\
\hline Nominal GDP (in millions of SEK) & & & & $2,443,630$ & & & & $3,126,018$ & & & & $3,089,181$ & & & & & $3,301,072$ \\
\hline
\end{tabular}

$1 /$ Including foreign branches.

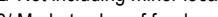

M Market value of funds.

unconsolidated basis. 
Table 3. Sweden: Financial Soundness Indicators: Banks, 2003-11

\begin{tabular}{|c|c|c|c|c|c|c|c|c|c|}
\hline & 2003 & 2004 & 2005 & 2006 & 2007 & 2008 & 2009 & 2010 & $\begin{array}{r}2011 \\
\text { Q1 }\end{array}$ \\
\hline \multicolumn{10}{|l|}{ Capital Adequacy } \\
\hline \multirow{2}{*}{$\begin{array}{l}\text { Regulatory capital to risk-weighted assets } 1 / \\
\text { of which: Four major banks } 2 /\end{array}$} & 10.5 & 10.6 & 10.5 & 10.5 & 10.2 & 10.7 & 13.0 & 12.6 & 12.4 \\
\hline & 10.0 & 10.1 & 10.1 & 10.0 & 9.8 & 10.2 & 12.7 & 12.0 & 11.7 \\
\hline \multirow{2}{*}{$\begin{array}{l}\text { Regulatory Tier I capital to risk-weighted assets } 1 / \\
\text { of which: Four major banks } 2 \text { / }\end{array}$} & 8.0 & 8.3 & 7.7 & 7.8 & 7.5 & 8.1 & 10.9 & 11.0 & 11.1 \\
\hline & 7.4 & 7.6 & 7.0 & 7.1 & 7.0 & 7.6 & 10.5 & 10.4 & 10.5 \\
\hline \multirow{2}{*}{$\begin{array}{l}\text { Capital as percent of assets (leverage ratio) } \\
\text { of which: Four major banks 2/ }\end{array}$} & 5.1 & 4.8 & 4.8 & 4.8 & 4.7 & 4.6 & 5.0 & 4.7 & 4.6 \\
\hline & 5.0 & 4.8 & 4.8 & 4.9 & 4.7 & 4.7 & 5.0 & 4.7 & 4.5 \\
\hline \multicolumn{10}{|l|}{ Asset quality and exposure } \\
\hline \multirow{2}{*}{$\begin{array}{l}\text { Nonperforming loans to total gross loans } \\
\text { of which: Four major banks } 2 /\end{array}$} & 2.0 & 1.2 & 0.9 & 0.8 & 0.6 & 1.1 & 2.0 & 1.9 & 1.7 \\
\hline & 1.9 & 1.1 & 0.8 & 0.8 & 0.6 & 1.0 & 2.0 & 1.9 & 1.7 \\
\hline \multirow{2}{*}{$\begin{array}{l}\text { Nonperforming loans net of loan-loss provisions to capital } \\
\text { of which: Four major banks } 2 /\end{array}$} & 11.9 & 4.8 & 3.1 & 4.3 & 3.4 & 7.4 & 10.7 & 9.9 & 10.1 \\
\hline & 11.5 & 4.0 & 2.7 & 3.9 & 3.1 & 6.5 & 11.0 & 10.6 & 10.7 \\
\hline \multirow{2}{*}{$\begin{array}{l}\text { Loan-loss provisions to nonperforming loans } \\
\text { of which: Four major banks } 2 /\end{array}$} & 49.4 & 66.2 & 69.7 & 56.1 & 58.3 & 49.1 & 55.4 & 44.3 & 43.9 \\
\hline & 50.3 & 70.6 & 73.6 & 58.0 & 60.4 & 47.1 & 53.7 & 43.8 & 43.2 \\
\hline \multicolumn{10}{|l|}{ Sectoral distribution of bank credit to the private sector (percent) } \\
\hline Sweden & 57.2 & 56.7 & 53.8 & 54.0 & 52.7 & 44.0 & 46.1 & 50.0 & 49.5 \\
\hline \multirow{2}{*}{$\begin{array}{l}\text { Nonfinancial corporations } \\
\text { Households }\end{array}$} & 24.3 & 23.2 & 21.8 & 20.6 & 20.9 & 19.1 & 18.3 & 18.9 & 18.9 \\
\hline & 21.5 & 22.1 & 20.6 & 20.6 & 19.0 & 18.1 & 20.4 & 22.1 & 21.7 \\
\hline Small personal companies & 6.5 & 6.6 & 6.4 & 6.3 & 6.1 & 5.6 & 6.1 & 6.8 & 6.7 \\
\hline Insurance companies & 0.4 & 0.4 & 0.5 & 0.5 & 0.6 & 0.2 & 0.2 & 0.3 & 0.3 \\
\hline Others & 4.6 & 4.3 & 4.5 & 6.0 & 6.1 & 1.0 & 1.2 & 1.9 & 1.9 \\
\hline Outside Sweden & 42.8 & 43.3 & 46.2 & 46.0 & 47.3 & 55.4 & 50.3 & 46.0 & 46.5 \\
\hline Geographical distribution of loans to total loans & & & & & & & & & \\
\hline Sweden & 63.6 & 47.4 & 45.8 & 48.0 & 48.1 & 48.5 & 48.7 & 50.1 & $\ldots$ \\
\hline Nordic countries & 11.9 & 26.7 & 28.2 & 24.4 & 25.9 & 25.4 & 27.8 & 27.9 & $\ldots$ \\
\hline Denmark & 6.3 & 12.6 & 13.3 & 8.6 & 9.0 & 8.4 & 10.3 & 11.6 & $\ldots$ \\
\hline Finland & 2.4 & 8.0 & 8.2 & 8.3 & 7.8 & 8.4 & 7.9 & 7.5 & $\ldots$ \\
\hline Norway & 3.3 & 6.1 & 6.8 & 7.5 & 9.1 & 8.6 & 9.6 & 8.9 & $\ldots$ \\
\hline Baltic countries & 2.2 & 2.0 & 3.3 & 5.2 & 5.0 & 5.4 & 4.9 & 4.1 & $\ldots$ \\
\hline Estonia & 1.1 & 1.0 & 1.6 & 1.9 & 1.9 & 2.1 & 1.8 & 1.6 & $\cdots$ \\
\hline Latvia & 0.4 & 0.4 & 0.8 & 1.7 & 1.5 & 1.6 & 1.4 & 1.2 & $\ldots$ \\
\hline Lithuania & 0.7 & 0.6 & 0.9 & 1.5 & 1.6 & 1.8 & 1.6 & 1.3 & $\ldots$ \\
\hline Other & 22.3 & 23.9 & 22.6 & 22.5 & 21.0 & 20.6 & 18.6 & 17.9 & $\ldots$ \\
\hline Large exposures as percent of tier 1 capital $3 /$ & 26.4 & 11.1 & 17.5 & 18.3 & 13.4 & 34.1 & 12.3 & 40.2 & $\ldots$ \\
\hline of which: Four major banks $3 /$ & 22.2 & 12.4 & 12.0 & 13.3 & 6.5 & 30.9 & 8.1 & 36.8 & $\ldots$ \\
\hline Earnings and profitability & & & & & & & & & \\
\hline Return on assets (Net income as percent of average total assets) & 0.6 & 0.7 & 0.8 & 0.8 & 0.8 & 0.5 & 0.3 & 0.4 & $\ldots$ \\
\hline of which: Four major banks $2 /$ & 0.6 & 0.7 & 0.7 & 0.8 & 0.8 & 0.6 & 0.2 & 0.5 & 0.4 \\
\hline Return on equity (Net income as percent of average equity capital) & 12.5 & 15.9 & 18.1 & 19.9 & 18.5 & 12.7 & 13.0 & 9.8 & $\ldots$ \\
\hline of which: Four major banks $2 /$ & 13.3 & 16.0 & 18.7 & 21.0 & 19.7 & 14.3 & 5.4 & 10.1 & 12.8 \\
\hline Net interest income as percent of gross income & 64.4 & 58.9 & 52.4 & 49.2 & 52.4 & 55.2 & 56.8 & 52.7 & 51.0 \\
\hline of which: Four major banks 2/ & 64.6 & 59.2 & 52.6 & 49.4 & 52.7 & 56.9 & 57.7 & 55.3 & 54.0 \\
\hline Trading income and foreign exchange gains (losses) to gross income & 3.0 & 5.1 & 9.6 & 10.5 & 8.3 & 8.6 & 11.7 & 11.6 & 12.8 \\
\hline of which: Four major banks 2/ & 3.5 & 5.4 & 10.0 & 11.2 & 9.6 & 9.8 & 13.6 & 12.6 & 13.4 \\
\hline Personnel expenses as percent of noninterest expenses & 54.0 & 53.7 & 56.0 & 57.4 & 57.1 & 55.0 & 53.2 & 52.6 & 54.9 \\
\hline of which: Four major banks 2/ & 55.9 & 55.7 & 58.4 & 60.3 & 60.0 & 59.2 & 57.1 & 57.4 & 60.4 \\
\hline Liquidity & & & & & & & & & \\
\hline Liquid assets as percent of total assets & 4.4 & 5.2 & 5.0 & 5.0 & 5.0 & 4.0 & 6.3 & 4.8 & 5.1 \\
\hline of which: Four major banks 2/ & 4.4 & 5.3 & 4.6 & 5.1 & 5.4 & 4.3 & 6.7 & 5.2 & 5.4 \\
\hline Liquid assets as percent of short-term liabilities & 29.3 & 30.6 & 31.6 & 32.1 & 34.1 & 23.6 & 43.6 & 44.4 & 46.4 \\
\hline of which: Four major banks 2/ & 32.1 & 34.7 & 33.3 & 37.5 & 43.8 & 30.5 & 54.7 & 58.9 & 60.8 \\
\hline Customer deposits as a percent of total (non-interbank) loans & 50.6 & 52.6 & 50.2 & 53.8 & 51.4 & 46.1 & 47.1 & 47.8 & 47.7 \\
\hline of which: Four major banks 2/ & 49.1 & 50.8 & 49.1 & 53.4 & 51.3 & 45.5 & 45.3 & 46.6 & 46.3 \\
\hline Noninterbank loans to noninterbank deposits & 142.6 & 130.8 & 137.4 & 135.7 & 139.8 & 139.6 & 144.8 & 154.9 & 155.8 \\
\hline of which: Four major banks $2 /$ & 150.2 & 139.6 & 145.1 & 143.1 & 148.4 & 149.7 & 156.1 & 165.9 & 166.9 \\
\hline Foreign exchange risk & & & & & & & & & \\
\hline Foreign currency-denominated loans as percent of total loans & 19.1 & 18.2 & 21.5 & 23.4 & 26.1 & 28.1 & 27.8 & 26.3 & $\ldots$ \\
\hline Foreign currency-denominated assets as percent of total assets & 23.9 & 26.9 & 28.9 & 28.9 & 31.4 & 32.5 & 31.0 & 30.2 & $\ldots$ \\
\hline Foreign currency-denominated liabilities as percent of total liabilities & 25.2 & 23.4 & 26.1 & 24.4 & 25.4 & 21.8 & 20.0 & 19.6 & $\ldots$ \\
\hline Exposure to derivatives & & & & & & & & & \\
\hline Gross asset position in derivatives as percent of Tier 1 capital & 152.6 & 176.7 & 164.7 & 110.7 & 132.0 & 336.8 & 210.8 & 222.7 & 192.4 \\
\hline Gross liability position in derivatives as percent of Tier 1 capital & 168.2 & 188.5 & 165.2 & 117.3 & 136.1 & 320.7 & 198.9 & 218.3 & 195.8 \\
\hline
\end{tabular}

Sources: Financial Supervisory Authority, Riksbank, and IMF staff estimates.

1/ From 2007, the calculation of capital base follows rules under Basel II.

2/ On consolidated basis

3/ From 2010 onward, exposures to credit institutions are included. 
Table 4. Sweden: Financial Soundness Indicators: Non-Banks, 2003-10

\begin{tabular}{|c|c|c|c|c|c|c|c|c|}
\hline & 2003 & 2004 & 2005 & 2006 & 2007 & 2008 & 2009 & 2010 \\
\hline \multicolumn{9}{|l|}{ Insurance sector } \\
\hline \multicolumn{9}{|l|}{ Solvency ratio (margin/required margin) } \\
\hline Life insurance companies & 9.0 & 8.4 & 11.2 & 13.8 & 14.9 & 8.4 & 7.8 & 11.7 \\
\hline Non-life insurance companies & 6.5 & 5.1 & 7.7 & 8.5 & 9.5 & 6.8 & 7.7 & 11.0 \\
\hline \multicolumn{9}{|l|}{ Households } \\
\hline Household debt as percent of GDP & 57.1 & 60.4 & 64.3 & 66.9 & 69.0 & 72.8 & 81.9 & 82.9 \\
\hline Household interest expense as percent of disposable income & 5.6 & 5.2 & 4.9 & 5.2 & 6.2 & 7.3 & 4.9 & 4.7 \\
\hline \multicolumn{9}{|l|}{ Corporate sector } \\
\hline $\begin{array}{l}\text { Debt stock as percent of GDP (non-financial sector borrowing from } \\
\text { financial sector) }\end{array}$ & 53.9 & 51.6 & 54.0 & 54.2 & 60.8 & 65.7 & 65.5 & 61.6 \\
\hline Total debt stock as percent of GDP & 74.5 & 70.4 & 72.5 & 69.4 & 79.4 & 92.6 & 92.3 & 86.8 \\
\hline \multicolumn{9}{|l|}{ Equity risk } \\
\hline OM Stockholm Stock Exchange Index (annual percent change) & -39.7 & 43.2 & 10.6 & 34.9 & 12.9 & -24.0 & -25.1 & 54.4 \\
\hline Equity prices of financial institutions (annual percent change) & -23.9 & 27.8 & 29.2 & 30.2 & 9.7 & -25.6 & -52.1 & 98.2 \\
\hline Market capitalization in percent of GDP & $\ldots$ & $\ldots$ & 230.5 & 260.8 & 257.2 & 140.7 & 188.5 & 216.2 \\
\hline \multicolumn{9}{|l|}{ Real estate markets (prices; year on year percent change) } \\
\hline One- or two dwelling buildings & 6.1 & 10.0 & 10.5 & 10.5 & 11.3 & -2.0 & 7.1 & 5.2 \\
\hline Greater Stockholm region & 0.7 & 8.8 & 9.1 & 11.6 & 15.6 & -3.2 & 5.9 & 6.9 \\
\hline Buildings for seasonal and secondary use & 7.9 & 9.4 & 13.7 & 7.6 & 13.3 & -2.8 & 12.2 & 0.9 \\
\hline
\end{tabular}

Sources: Financial Supervisory Authority; Riksbank; and IMF staff estimates. 
Table 5. Sweden: General Government Financial Accounts, 2007-2014

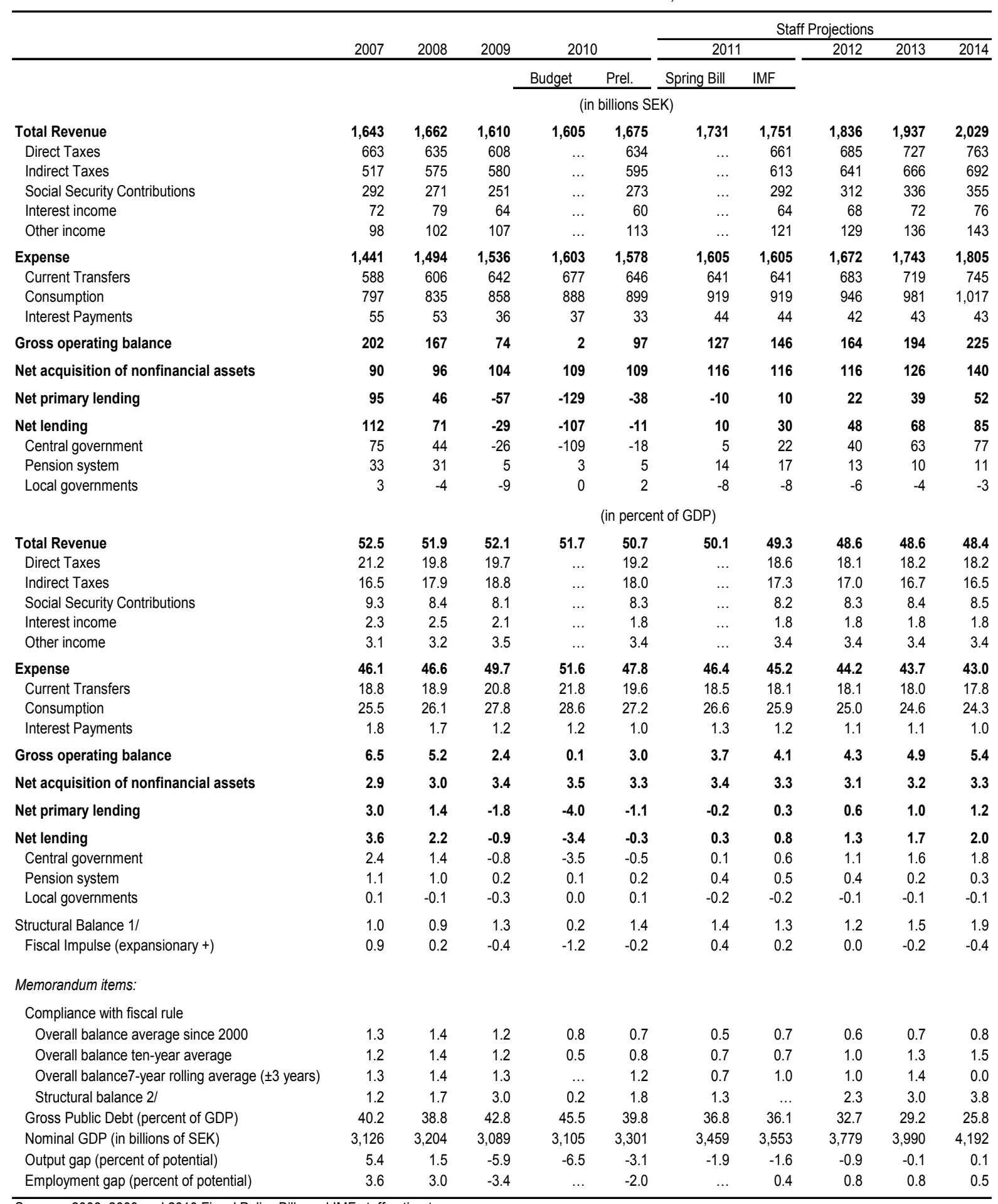

Sources: 2008, 2009 and 2010 Fiscal Policy Bills and IMF staff estimates.

1/ Staff measure

2/ Authorities' measure 
Table 6. Sweden: Public Sector Balance Sheet, 2003-11

\begin{tabular}{|c|c|c|c|c|c|c|c|c|c|}
\hline & 2003 & 2004 & 2005 & 2006 & 2007 & 2008 & 2009 & 2010 & 2011 \\
\hline & \multicolumn{9}{|c|}{ (In billions of SEK) } \\
\hline Assets & 2,622 & 2,779 & 3,023 & 3,349 & 3,489 & 3,348 & 3,289 & 3,462 & 3,673 \\
\hline Financial assets & 1,534 & 1,672 & 1,884 & 2,138 & 2,203 & 2,030 & 2,018 & 2,104 & 2,212 \\
\hline Cash \& ST securities & 57 & 57 & 65 & 87 & 96 & 146 & 149 & 152 & 157 \\
\hline Equity and mutual funds & 725 & 785 & 921 & 1,067 & 1,109 & 904 & 872 & 931 & 1,002 \\
\hline Other & 752 & 829 & 898 & 984 & 998 & 980 & 998 & 1,021 & 1,052 \\
\hline Capital stock net of depreciation & 1,088 & 1,107 & 1,139 & 1,211 & 1,286 & 1,318 & 1,271 & 1,358 & 1,461 \\
\hline Liabilities & 1,618 & 1,724 & 1,808 & 1,704 & 1,600 & 1,593 & 1,658 & 1,673 & 1,670 \\
\hline Financial liabilities & 1,618 & 1,724 & 1,808 & 1,704 & 1,600 & 1,593 & 1,658 & 1,673 & 1,670 \\
\hline Gross debt & 1,316 & 1,339 & 1,396 & 1,333 & 1,257 & 1,243 & 1,321 & 1,313 & 1,282 \\
\hline Other & 301 & 384 & 412 & 371 & 343 & 350 & 337 & 360 & 388 \\
\hline Current net worth & 1,005 & 1,055 & 1,215 & 1,645 & 1,889 & 1,755 & 1,631 & 1,789 & 2,003 \\
\hline NPV of future fiscal policies (50 years) $1 /$ & 2,502 & 2,614 & 2,622 & 2,387 & 2,348 & 2,636 & 2,907 & 2,924 & 2,892 \\
\hline Intertemporal net worth & 3,507 & 3,669 & 3,837 & 4,032 & 4,237 & 4,392 & 4,538 & 4,713 & 4,894 \\
\hline \multirow[t]{2}{*}{ Intertemporal financial net worth 3 / } & 2,418 & 2,562 & 2,698 & 2,821 & 2,951 & 3,074 & 3,267 & 3,355 & 3,433 \\
\hline & \multicolumn{9}{|c|}{ (In percent of GDP) } \\
\hline Assets & 103.0 & 104.4 & 109.2 & 113.7 & 111.6 & 104.5 & 106.5 & 104.9 & 103.4 \\
\hline Financial assets & 60.3 & 62.8 & 68.0 & 72.6 & 70.5 & 63.4 & 65.3 & 63.7 & 62.3 \\
\hline Cash \& ST securities & 2.2 & 2.1 & 2.4 & 3.0 & 3.1 & 4.6 & 4.8 & 4.6 & 4.4 \\
\hline Equity and mutual funds & 28.5 & 29.5 & 33.2 & 36.2 & 35.5 & 28.2 & 28.2 & 28.2 & 28.2 \\
\hline Other & 29.6 & 31.2 & 32.4 & 33.4 & 31.9 & 30.6 & 32.3 & 30.9 & 29.6 \\
\hline Capital stock net of depreciation & 42.8 & 41.6 & 41.1 & 41.1 & 41.1 & 41.1 & 41.1 & 41.1 & 41.1 \\
\hline Liabilities & 63.6 & 64.8 & 65.3 & 57.9 & 51.2 & 49.7 & 53.7 & 50.7 & 47.0 \\
\hline Financial liabilities & 63.6 & 64.8 & 65.3 & 57.9 & 51.2 & 49.7 & 53.7 & 50.7 & 47.0 \\
\hline Gross debt & 51.7 & 50.3 & 50.4 & 45.3 & 40.2 & 38.8 & 42.8 & 39.8 & 36.1 \\
\hline Other & 11.8 & 14.4 & 14.9 & 12.6 & 11.0 & 10.9 & 10.9 & 10.9 & 10.9 \\
\hline Current net worth & 39.5 & 39.6 & 43.9 & 55.9 & 60.4 & 54.8 & 52.8 & 54.2 & 56.4 \\
\hline NPV of future fiscal policies (50 years) $2 /$ & 98.3 & 98.2 & 94.7 & 81.1 & 75.1 & 82.3 & 94.1 & 88.6 & 81.4 \\
\hline Intertemporal net worth & 137.8 & 137.9 & 138.6 & 136.9 & 135.5 & 137.1 & 146.9 & 142.8 & 137.8 \\
\hline Intertemporal financial net worth $2 /$ & 95.0 & 96.3 & 97.4 & 95.8 & 94.4 & 95.9 & 105.8 & 101.6 & 96.6 \\
\hline \multicolumn{10}{|l|}{ Memorandum items: } \\
\hline GDP (SEK billions) & 2,545 & 2,661 & 2,769 & 2,944 & 3,126 & 3,204 & 3,089 & 3,301 & 3,553 \\
\hline
\end{tabular}

1/ Two scenarios: one with aging costs of 2.2 percent of GDP through 2050; and a second with aging costs of 8.0 percent of GDP through 2050.

1 / Stream of discounted projected future primary fiscal balances under current policies and with the indicated aging costs. Discount rate is the average cost of government funding.

2/ Considers only financial assets and liabilities (i.e. excludes capital stock). This measure is a

liquidity indicator whereas the comprehensive net worth is a solvency indicator.

Sources: Swedisch authorities; and Fund staff calculations. 
Table 7. Sweden: Balance of Payments Accounts, 2006-15

\begin{tabular}{|c|c|c|c|c|c|c|c|c|c|c|}
\hline & \multirow[b]{2}{*}{2006} & \multirow[b]{2}{*}{2007} & \multirow[b]{2}{*}{2008} & \multirow[b]{2}{*}{2009} & \multirow[b]{2}{*}{2010} & \multicolumn{5}{|c|}{ Projections } \\
\hline & & & & & & 2011 & 2012 & 2013 & 2014 & 2015 \\
\hline & \multicolumn{10}{|c|}{ (in SEK billions) } \\
\hline Current Account Balance & 248 & 289 & 278 & 218 & 209 & 213 & 214 & 219 & 226 & 233 \\
\hline Trade Balance & 230 & 226 & 211 & 205 & 197 & 206 & 204 & 207 & 211 & 212 \\
\hline Exports of G\&S & 1,471 & 1,585 & 1,670 & 1,473 & 1,618 & 1,684 & 1,725 & 1,791 & 1,807 & 1,840 \\
\hline Imports of G\&S & 1,241 & 1,360 & 1,459 & 1,268 & 1,421 & 1,478 & 1,521 & 1,584 & 1,595 & 1,628 \\
\hline Factor income, net & 55 & 96 & 109 & 52 & 57 & 48 & 53 & 58 & 63 & 71 \\
\hline Current Transfers, net & -37 & -33 & -42 & -39 & -45 & -41 & -43 & -46 & -48 & -51 \\
\hline Financial Account Balance & -241 & -77 & 155 & -71 & -307 & -221 & -244 & -226 & -247 & -269 \\
\hline Investment Abroad ${ }^{1}$ & -628 & -656 & 248 & 571 & 215 & -264 & -331 & -347 & -434 & -637 \\
\hline o/w Reserves & -11 & 2 & 4 & -116 & 2 & 0 & 0 & 0 & 0 & 0 \\
\hline \multirow[t]{2}{*}{ Investment in Sweden ${ }^{2}$} & 387 & 579 & -93 & -643 & -522 & 44 & 88 & 120 & 187 & 369 \\
\hline & \multicolumn{10}{|c|}{ (in percent of GDP) } \\
\hline Current Account Balance & 8.4 & 9.2 & 8.7 & 7.0 & 6.3 & 6.0 & 5.7 & 5.5 & 5.4 & 5.3 \\
\hline Trade Balance & 7.8 & 7.2 & 6.6 & 6.6 & 6.0 & 5.8 & 5.4 & 5.2 & 5.1 & 4.8 \\
\hline Exports of G\&S & 50.0 & 50.7 & 52.1 & 47.7 & 49.0 & 47.4 & 45.7 & 45.0 & 43.2 & 42.0 \\
\hline Imports of G\&S & 42.2 & 43.5 & 45.5 & 41.0 & 43.0 & 41.6 & 40.3 & 39.8 & 38.1 & 37.1 \\
\hline Factor income, net & 1.9 & 3.1 & 3.4 & 1.7 & 1.7 & 1.4 & 1.4 & 1.5 & 1.5 & 1.6 \\
\hline Current Transfers, net & -1.3 & -1.1 & -1.3 & -1.3 & -1.4 & -1.2 & -1.2 & -1.2 & -1.2 & -1.2 \\
\hline Financial Account Balance & -8.2 & -2.5 & 4.8 & -2.3 & -9.3 & -6.2 & -6.5 & -5.7 & -5.9 & -6.1 \\
\hline Investment Abroad ${ }^{1}$ & -21.3 & -21.0 & 7.7 & 18.5 & 6.5 & -7.4 & -8.8 & -8.7 & -10.4 & -14.5 \\
\hline Direct Investment & -6.7 & -8.4 & -6.4 & -6.4 & -6.6 & -5.6 & -5.6 & -5.6 & -5.6 & -5.6 \\
\hline Portfolio Investment & -8.4 & -10.7 & -3.1 & -4.6 & -4.1 & -5.1 & -5.1 & -5.1 & -5.1 & -5.1 \\
\hline Financial Derivatives & 7.3 & 8.5 & 16.9 & 29.7 & 23.7 & 7.8 & 7.6 & 8.4 & 8.3 & 4.7 \\
\hline Other Investment & -13.1 & -10.4 & 0.4 & 3.5 & -6.6 & -4.6 & -5.7 & -6.4 & -7.9 & -8.6 \\
\hline Reserves & -0.4 & 0.1 & 0.1 & -3.8 & 0.1 & 0.0 & 0.0 & 0.0 & 0.0 & 0.0 \\
\hline Investment in Sweden ${ }^{2}$ & 13.1 & 18.5 & -2.9 & -20.8 & -15.8 & 1.2 & 2.3 & 3.0 & 4.5 & 8.4 \\
\hline Direct Investment & 7.3 & 6.0 & 7.6 & 2.6 & 1.1 & 5.3 & 5.3 & 5.3 & 5.3 & 5.3 \\
\hline Portfolio Investment & 3.4 & 13.9 & -3.1 & 20.3 & 8.4 & 7.6 & 7.6 & 7.6 & 7.6 & 7.6 \\
\hline Financial Derivatives & -7.2 & -8.7 & -16.4 & -30.4 & -22.8 & -14.2 & -13.1 & -12.4 & -11.0 & -7.0 \\
\hline Other Investment & 9.7 & 7.3 & 9.0 & -13.3 & -2.5 & 2.5 & 2.5 & 2.5 & 2.5 & 2.5 \\
\hline Errors and Omissions & 0.4 & -6.7 & -13.4 & -4.6 & 3.1 & 0.0 & 0.0 & 0.0 & 0.0 & 0.0 \\
\hline \multicolumn{11}{|l|}{ Exports of G\&S } \\
\hline Value & 12.9 & 7.7 & 5.3 & -11.8 & 9.8 & 4.1 & 2.4 & 3.8 & 0.9 & 1.8 \\
\hline Volume & 9.7 & 5.7 & 1.3 & -12.4 & 10.3 & 7.0 & 5.6 & 5.4 & 2.3 & 2.4 \\
\hline Deflator & 3.0 & 1.9 & 4.0 & 0.7 & -0.4 & -2.7 & -3.0 & -1.5 & -1.4 & -0.5 \\
\hline \multicolumn{11}{|l|}{ Imports of G\&S } \\
\hline Value & 12.6 & 9.5 & 7.3 & -13.1 & 12.0 & 4.1 & 2.9 & 4.2 & 0.7 & 2.0 \\
\hline Volume & 9.0 & 8.9 & 2.8 & -13.1 & 12.2 & 7.3 & 6.1 & 6.2 & 2.0 & 2.5 \\
\hline Deflator & 3.3 & 0.6 & 4.4 & 0.0 & -0.2 & -3.0 & -3.1 & -1.9 & -1.3 & -0.5 \\
\hline
\end{tabular}

${ }^{1}$ Positive number indicates a decumulation of foreign assets.

${ }^{2}$ Positive number indicates an accumulation of foreign assets.

Source: Statistics Sweden; and IMF staff projections. 
Table 8. Sweden: International Investment Position, 2006-15

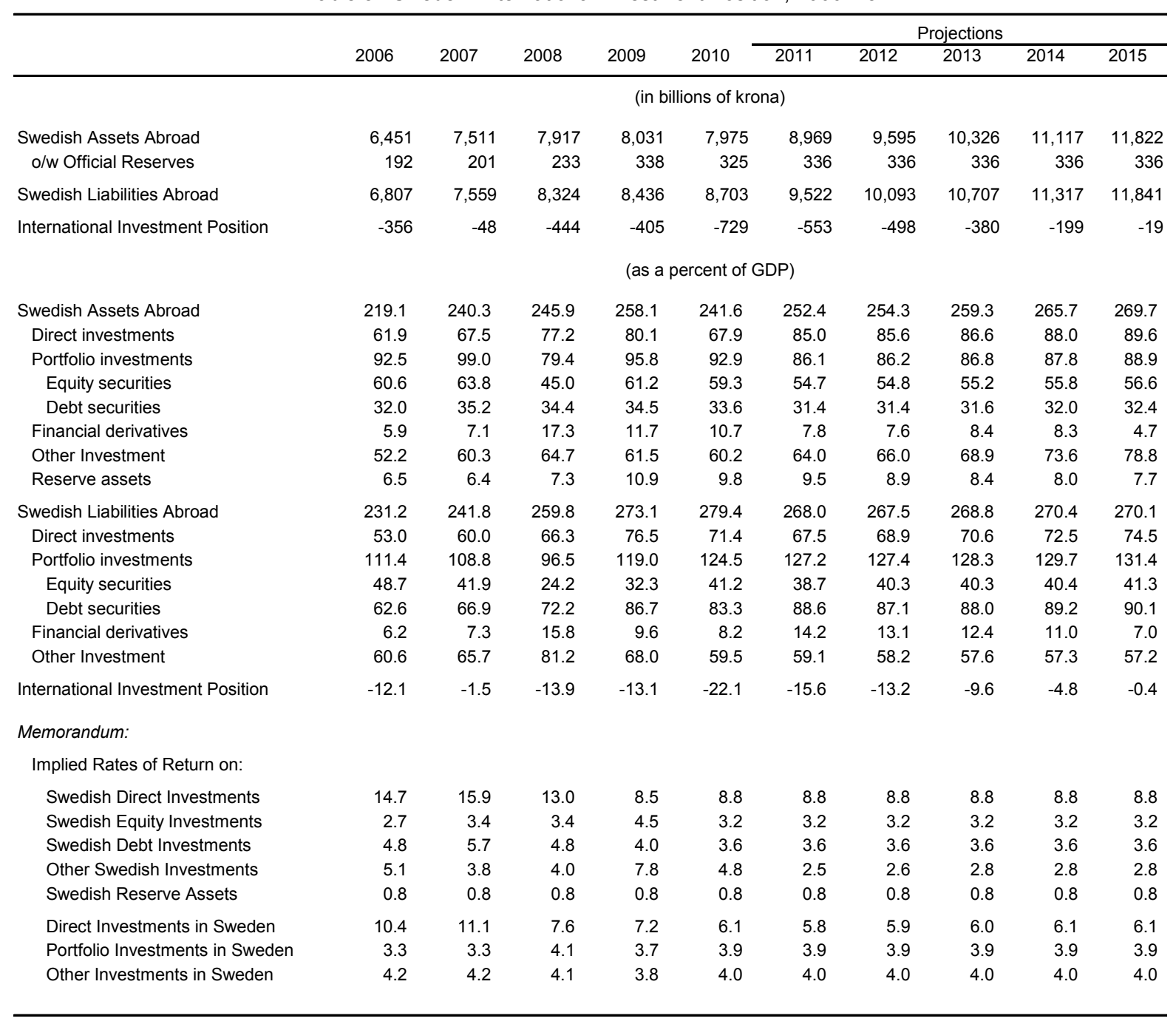

Sources: Statistics Sweden; and IMF staff projections. 
Table 9. Sweden: Medium-term Scenario, 2008-16

\begin{tabular}{|c|c|c|c|c|c|c|c|c|c|}
\hline & 2008 & 2009 & 2010 & 2011 & 2012 & 2013 & 2014 & 2015 & 2016 \\
\hline \multicolumn{10}{|c|}{ (percentage change, unless o.w.) } \\
\hline Real GDP & -0.6 & -5.3 & 5.5 & 4.4 & 3.8 & 3.5 & 3.0 & 2.5 & 2.5 \\
\hline Final domestic demand & 0.6 & -3.3 & 3.8 & 2.8 & 3.6 & 2.9 & 2.9 & 2.8 & 2.8 \\
\hline Private consumption & 0.0 & -0.4 & 3.5 & 2.5 & 2.4 & 2.5 & 2.5 & 2.5 & 2.5 \\
\hline Public consumption & 1.0 & 1.7 & 2.6 & 0.9 & 0.6 & 0.6 & 0.6 & 0.6 & 0.6 \\
\hline Fixed investment & 1.4 & -16.3 & 6.3 & 8.9 & 10.0 & 6.5 & 6.0 & 6.0 & 6.0 \\
\hline Change in stocks $1 /$ & -0.5 & -1.6 & 2.1 & 0.0 & 0.0 & 0.0 & 0.0 & 0.0 & 0.0 \\
\hline Net exports $1 /$ & -0.6 & -0.8 & -0.1 & 1.6 & 0.8 & 0.6 & 0.5 & 0.4 & 0.4 \\
\hline Exports & 1.7 & -13.4 & 10.7 & 9.4 & 6.2 & 6.2 & 3.5 & 4.3 & 4.3 \\
\hline Imports & 3.5 & -13.7 & 12.7 & 7.0 & 5.6 & 6.0 & 3.0 & 4.3 & 4.3 \\
\hline Current account 2/ & 8.7 & 7.0 & 6.3 & 6.0 & 5.7 & 5.5 & 5.4 & 5.3 & 5.3 \\
\hline Inflation 3/ & 3.3 & 2.0 & 1.9 & 3.0 & 2.5 & 2.0 & 2.0 & 2.0 & 2.0 \\
\hline Unemployment rate 3 / & 6.2 & 8.3 & 8.4 & 7.4 & 6.6 & 5.8 & 5.5 & 5.5 & 5.5 \\
\hline Potential output & 3.2 & 2.1 & 2.5 & 2.8 & 3.1 & 2.7 & 2.8 & 2.4 & 2.4 \\
\hline Output gap 4/ & 1.5 & -5.9 & -3.1 & -1.6 & -0.9 & -0.1 & 0.1 & 0.2 & 0.3 \\
\hline
\end{tabular}

1/ Contribution to real GDP growth.

2/ In percent of nominal GDP.

$3 / \mathrm{HICP}$ annual average, in percent.

4/ In percent of potential GDP.

Source: IMF staff projections. 
Figure 1. Sweden: The Long View, 1996-2011
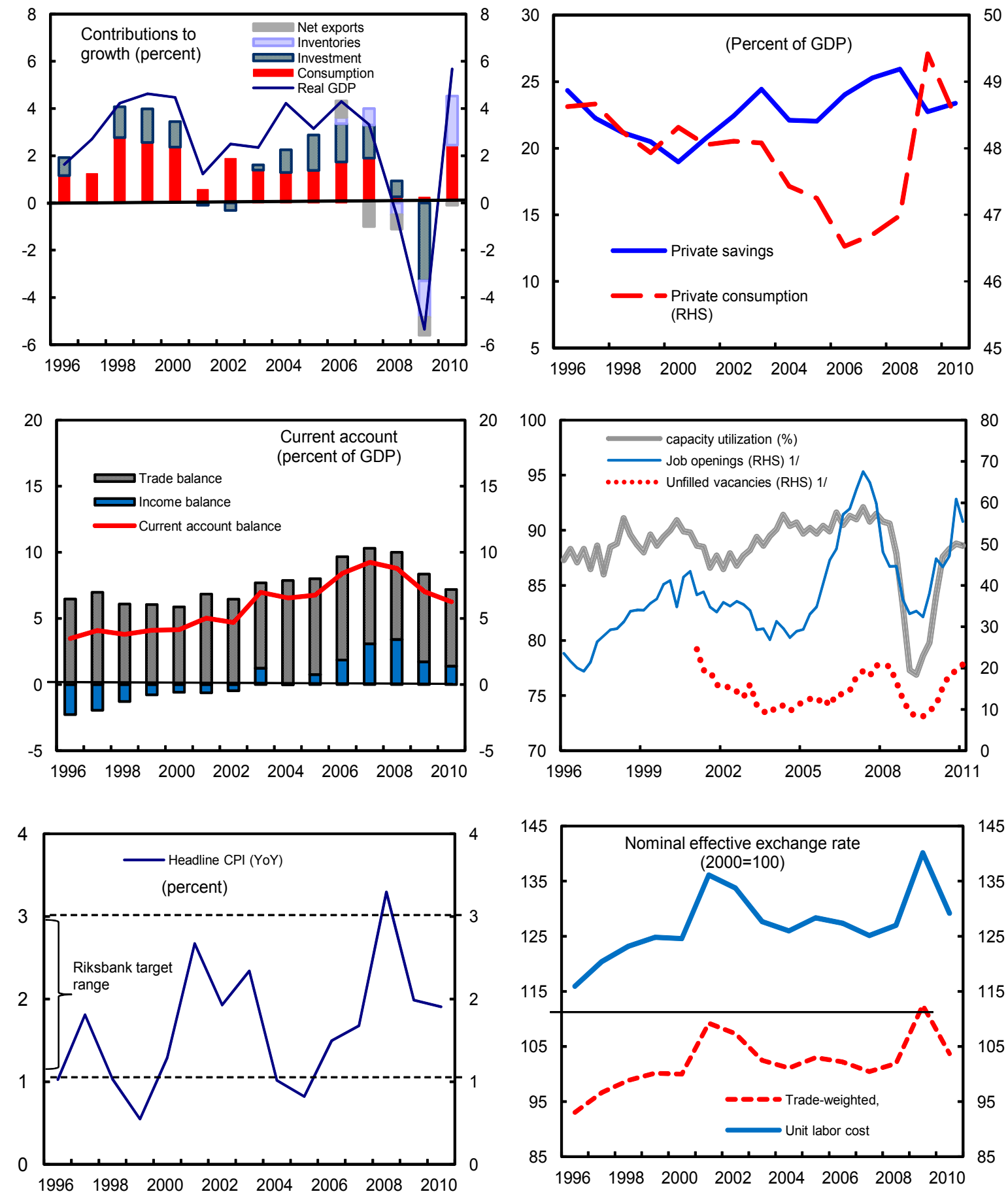

1/ In thousands.

Sources: Haver Analytics; Konjunkturinstitutet; Statistics Sweden; and IMF staff calculations. 
Figure 2. Sweden: A Strong Recovery, 2007-11

Real GDP has bounced back

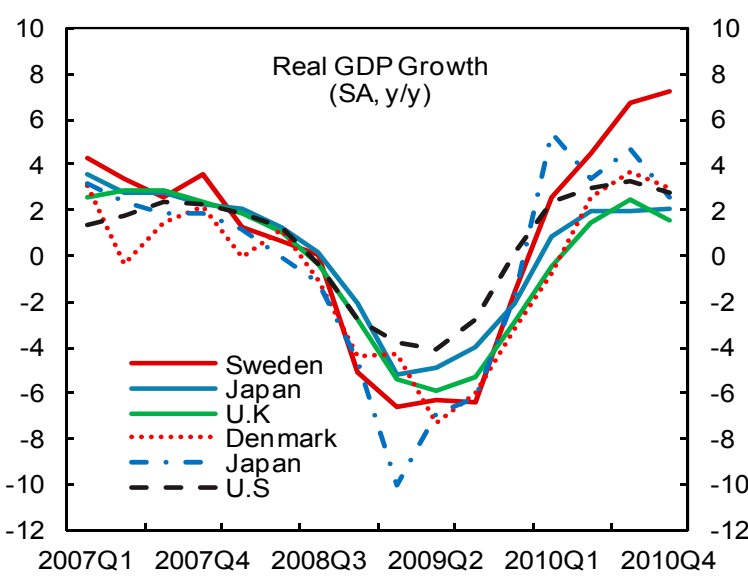

Exports of capital goods have led the way

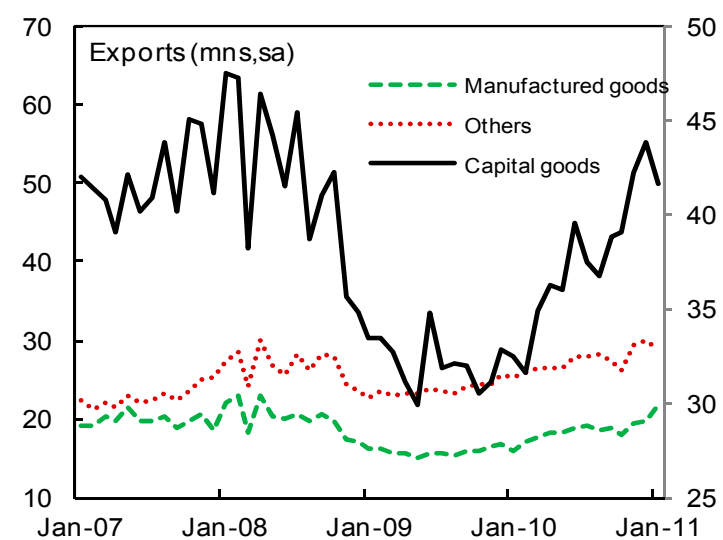

And domestic demand has made an important contribution

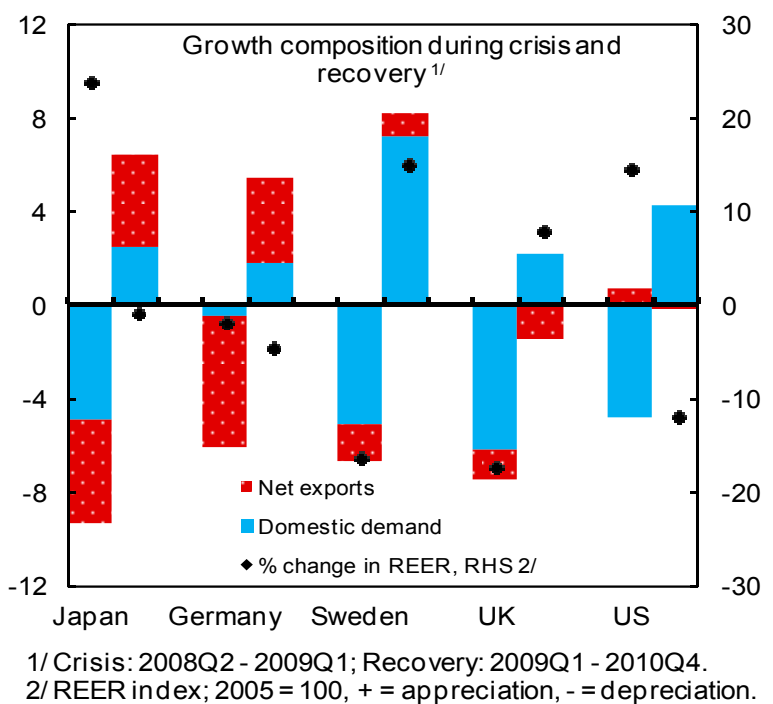

On the back of a strong recovery in exports

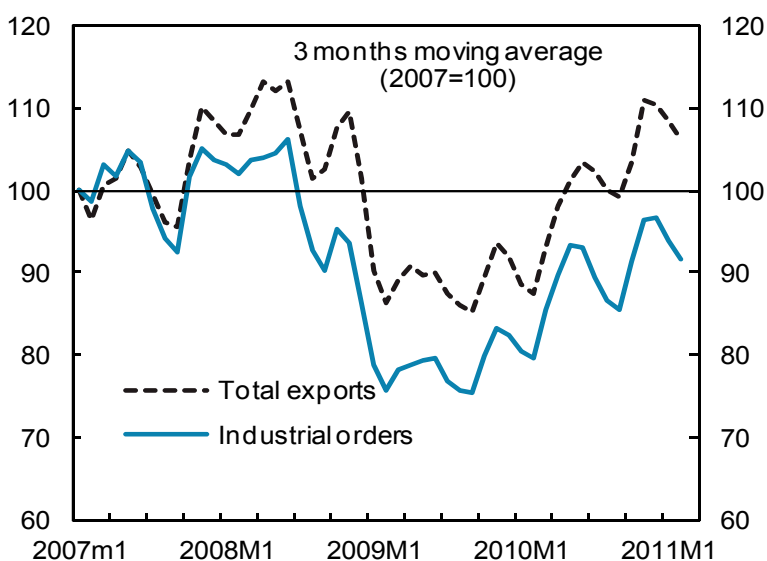

Reflected in industrial production

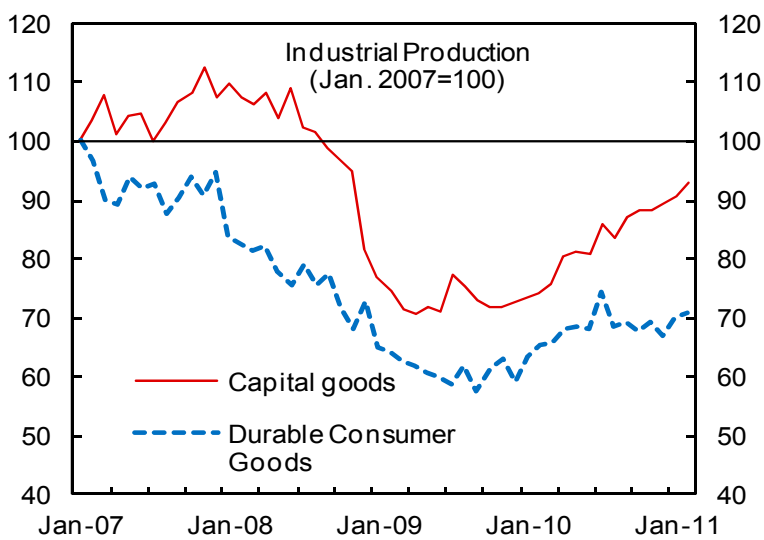

But unemployment remains higher than elsewhere

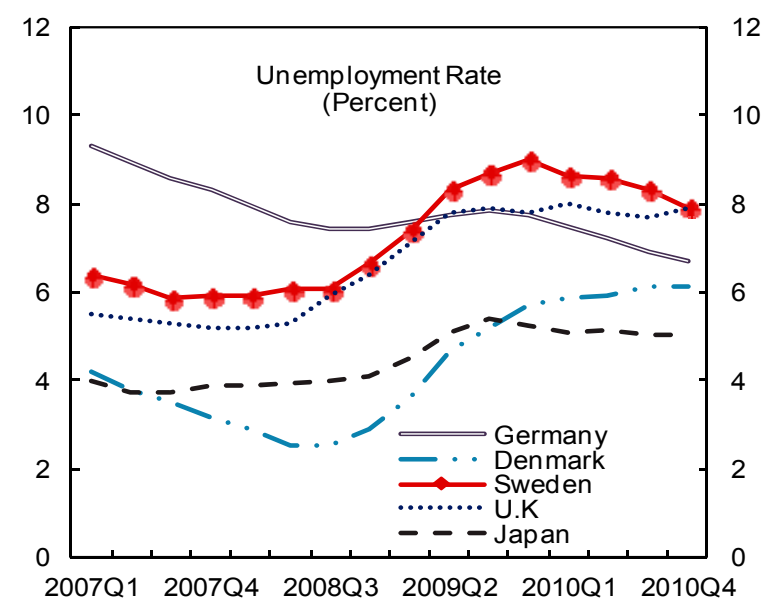

Sources: Haver; INS; and IMF staff calculations. 
Figure 3. Sweden: Household Balance Sheets and Consumption, 2004-11
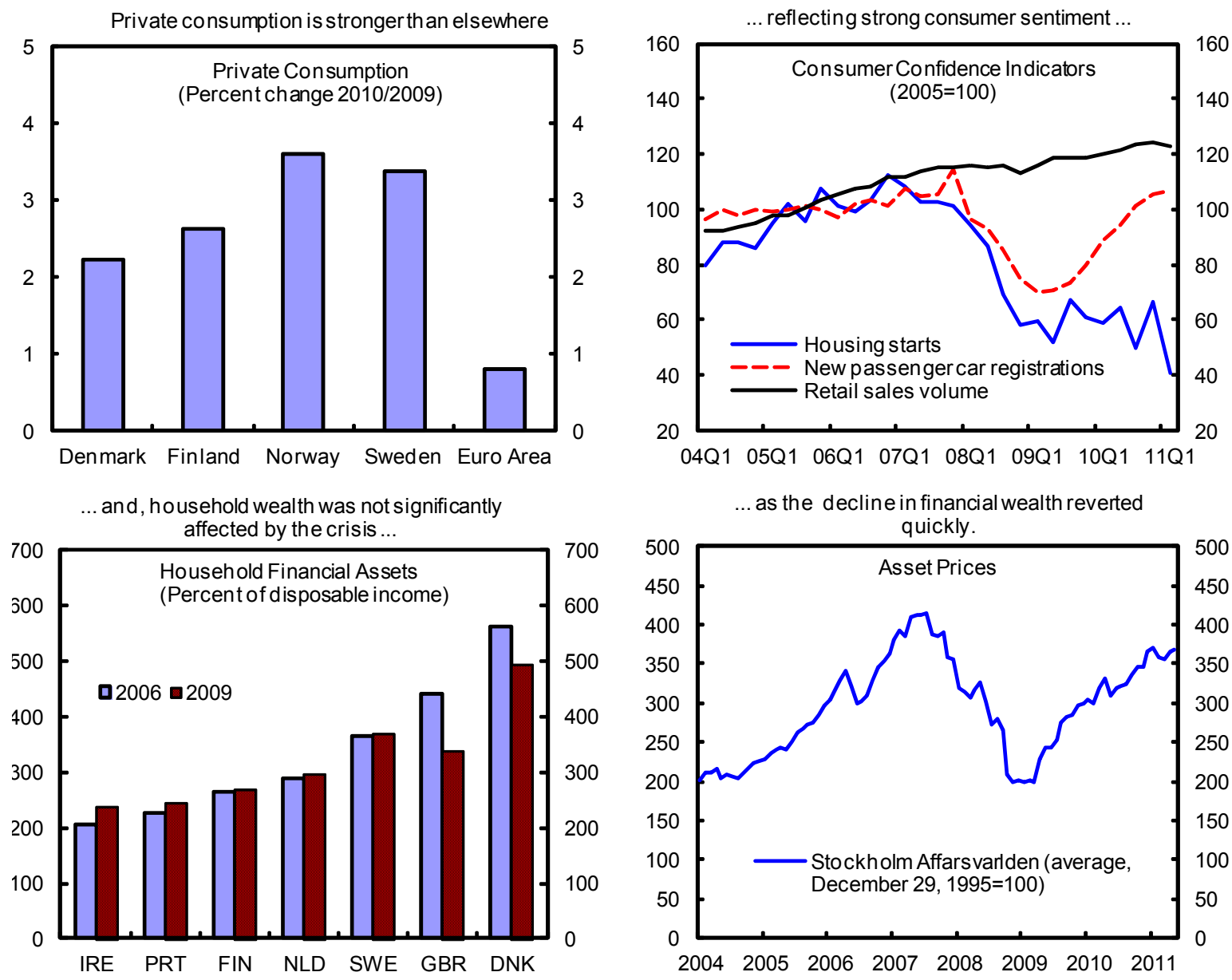

Overall, the decline in nethousehold wealth was small compared to peers.
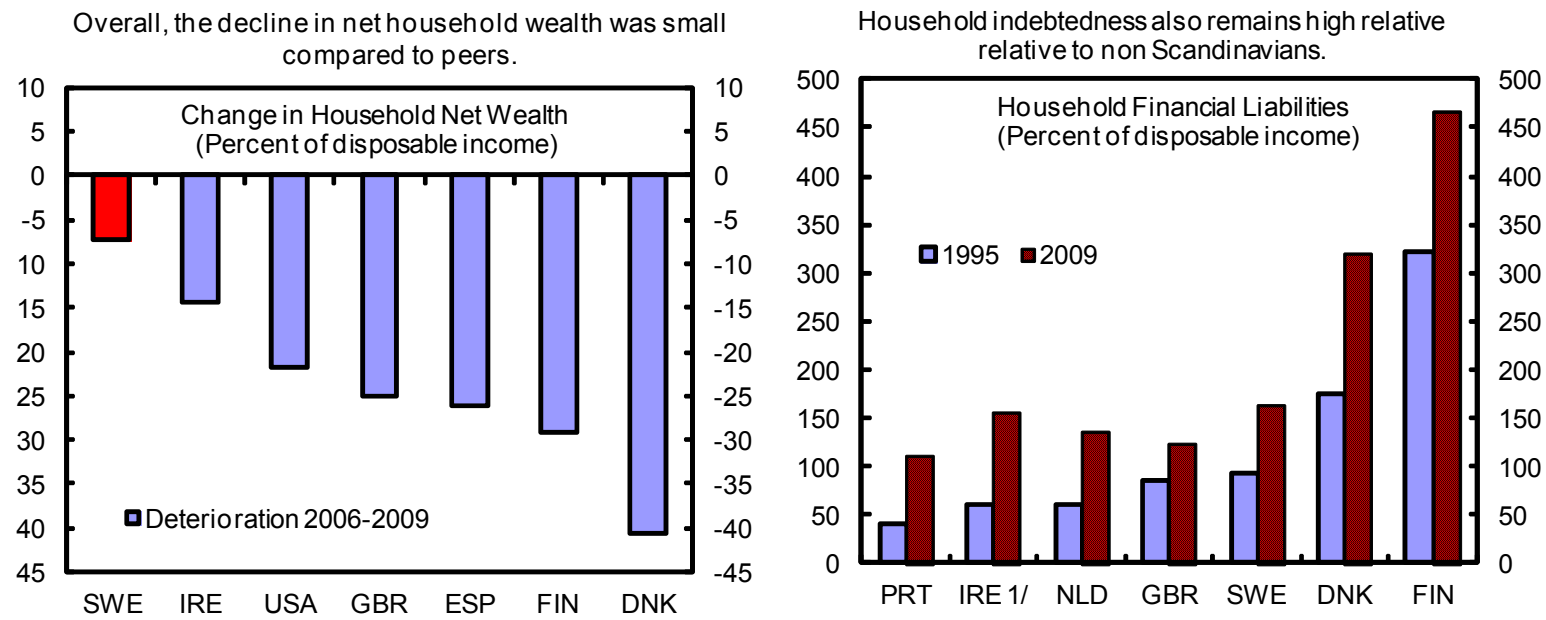

Sources: Eurostat; Haver; Statistics Sweden; and IMF staff calculations.

${ }^{1 /}$ Data for Ireland starts in 2001. 
Figure 4. Sweden: Selected Financial Markets Indicators, 2007-11

Exchange rates have continued to appreciate and returned to pre-crisis levels...

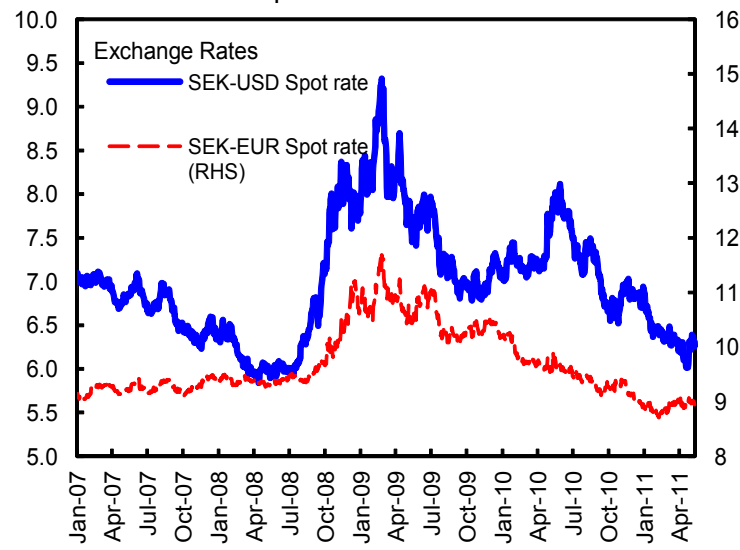

...so do government bond markets...

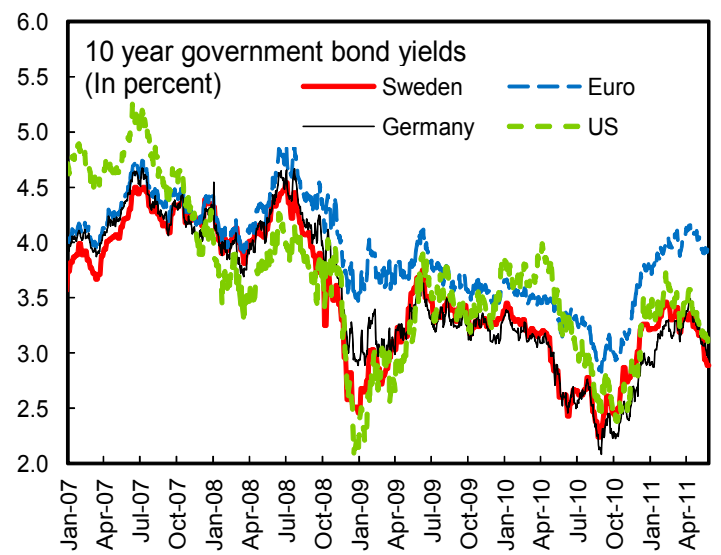

Interbank market functions have largely normalized.

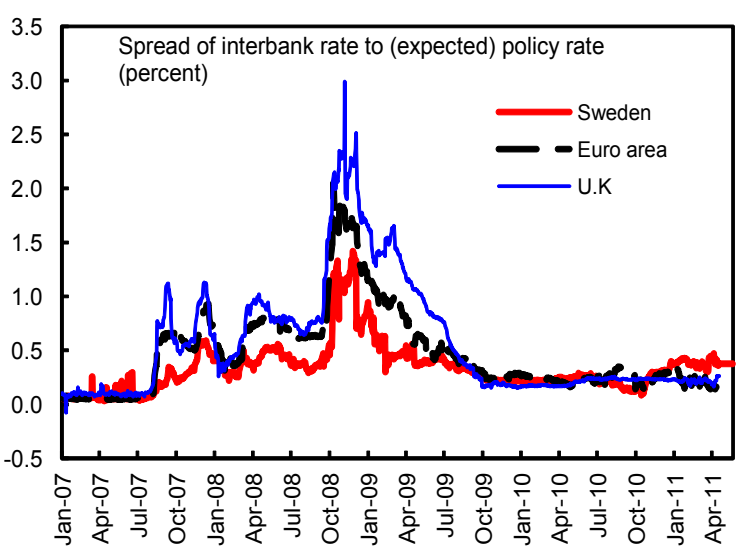

stock market has outperformed the euro area...

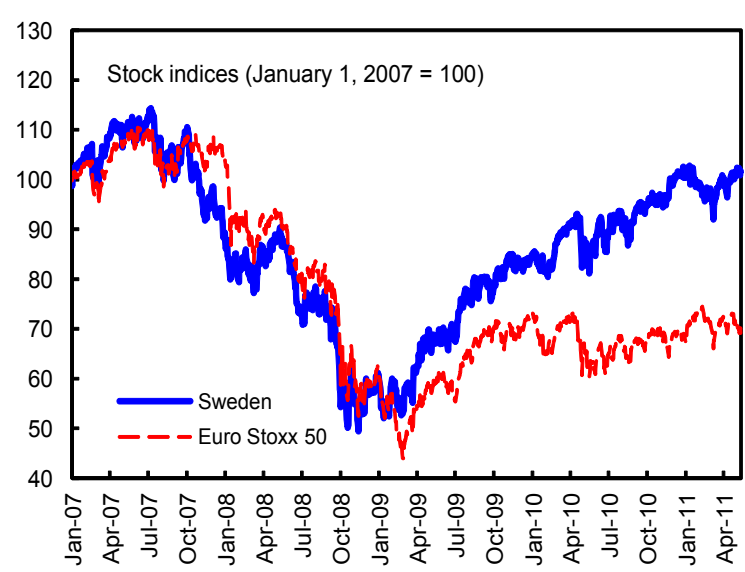

...and sovereign risk indicators for Sweden.

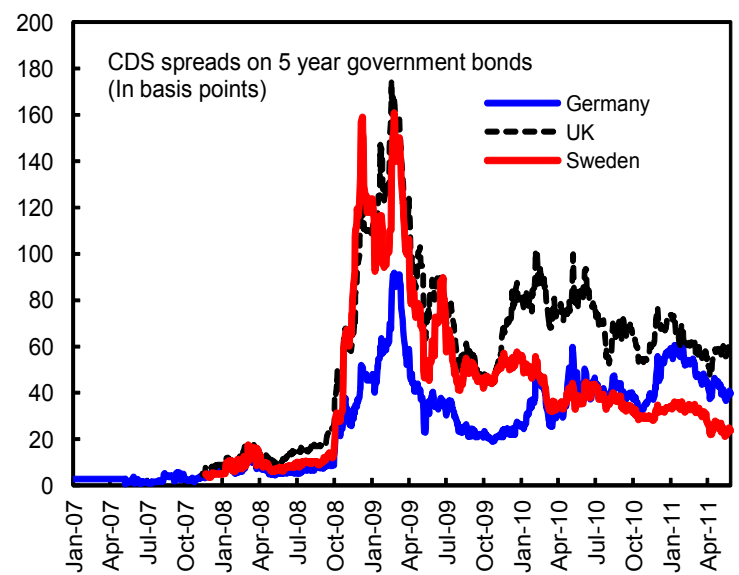

But, mortgage bond yileds remain at elevated level.

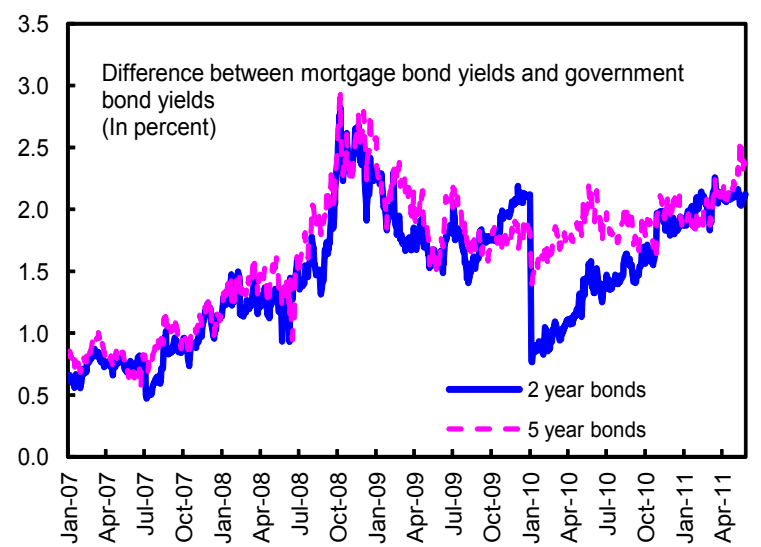

Sources: Thomson Financial/Datastream; Bloomberg; and Haver. 
Figure 5. Sweden: Inflation and Monetary Policy, 2007-11

Inflation stays at around the target...

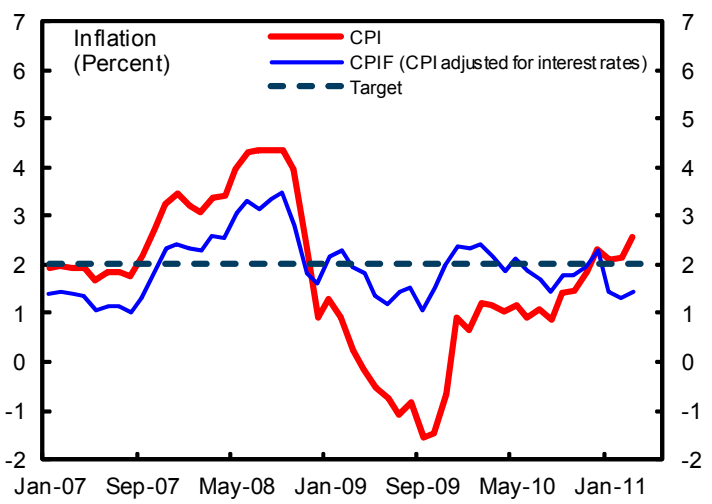

Market inflation expectations crept up but are returning to the target.

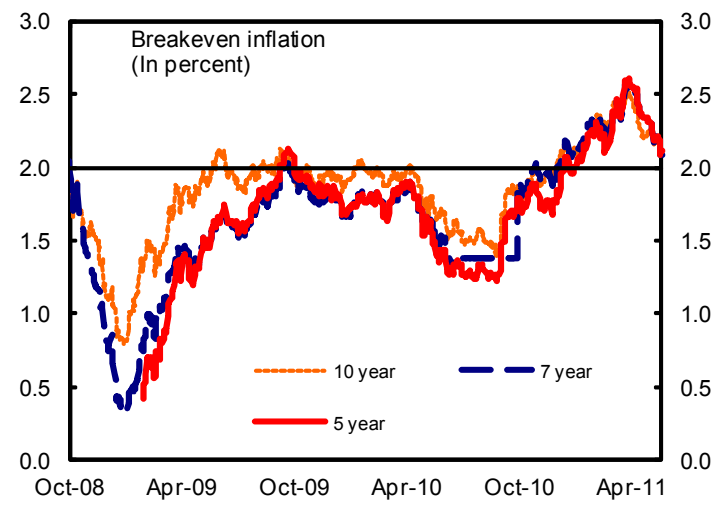

...while business survey results suggest tighter labor market conditions.

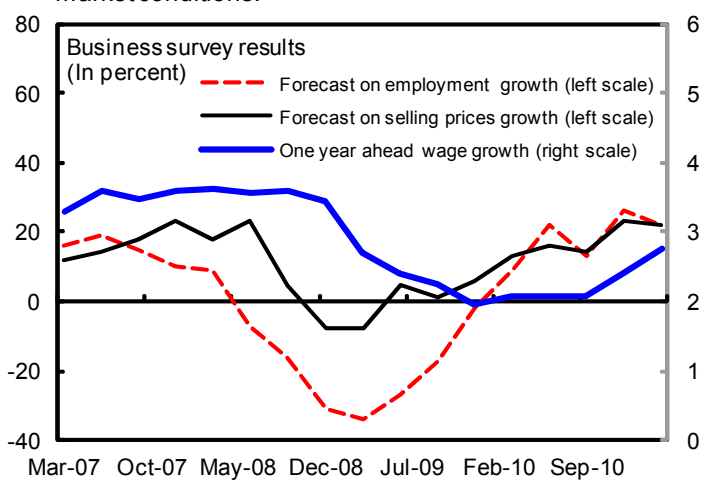

...and wage growth has been moderate.

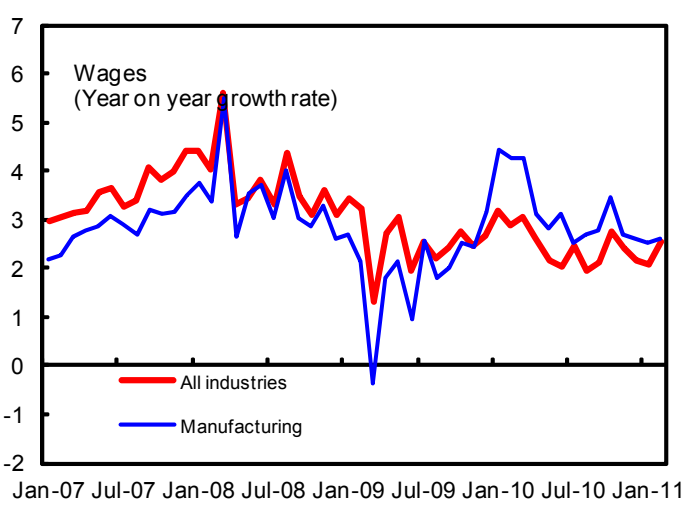

The policy interest rate has been raised, but monetary policy stance remains accommodative...

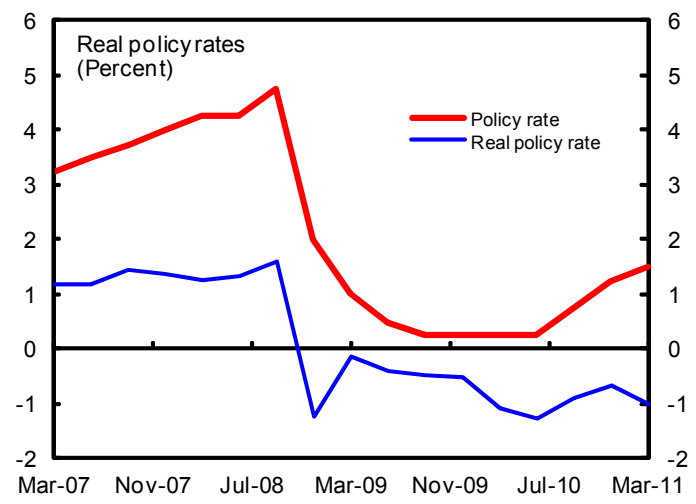

The Riksbank is expected to further raise the policy interest rate.

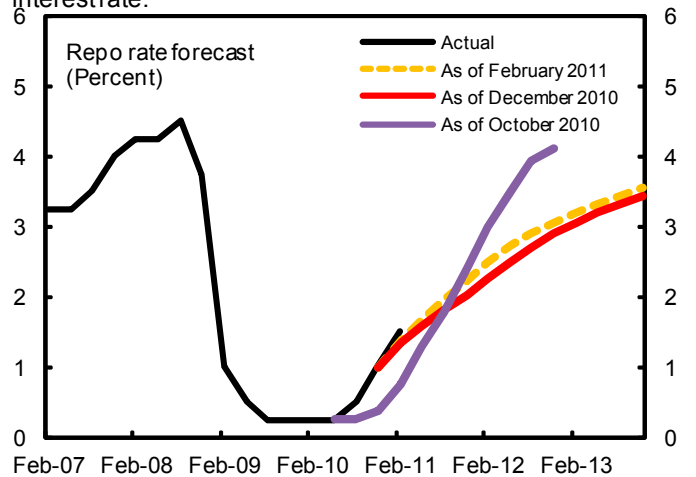

Sources: Thomson Financial/Datastream; Bloomberg; Haver, and Riksbank. 
Figure 6. Sweden: Fiscal Developments

Sweden's deficit is lower than elsewhere

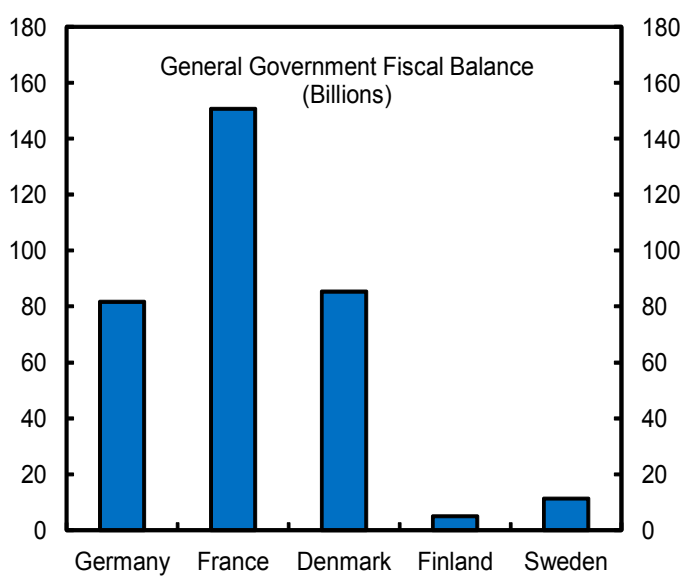

Fiscal policy has been countercyclical

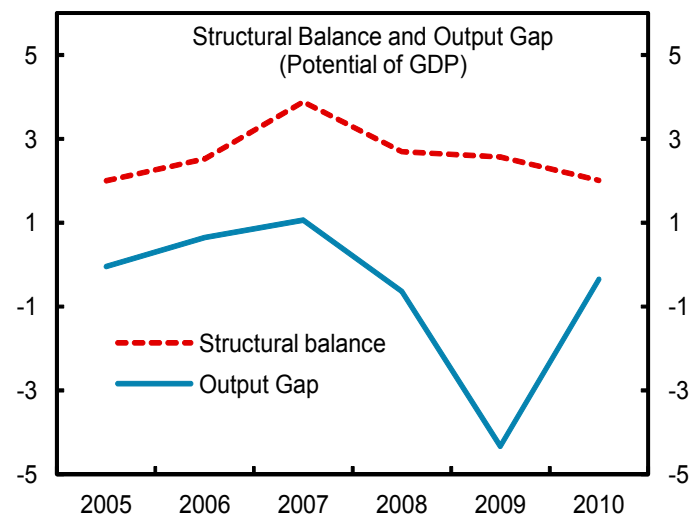

Fiscal targets have been exceeded

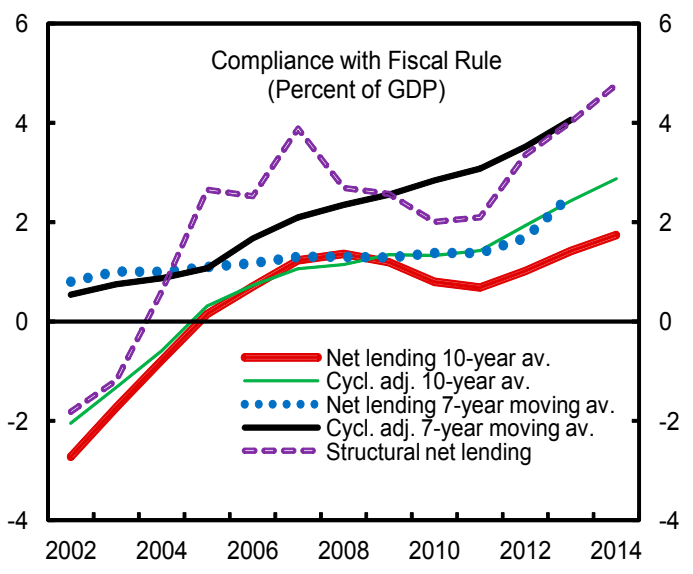

And so is debt

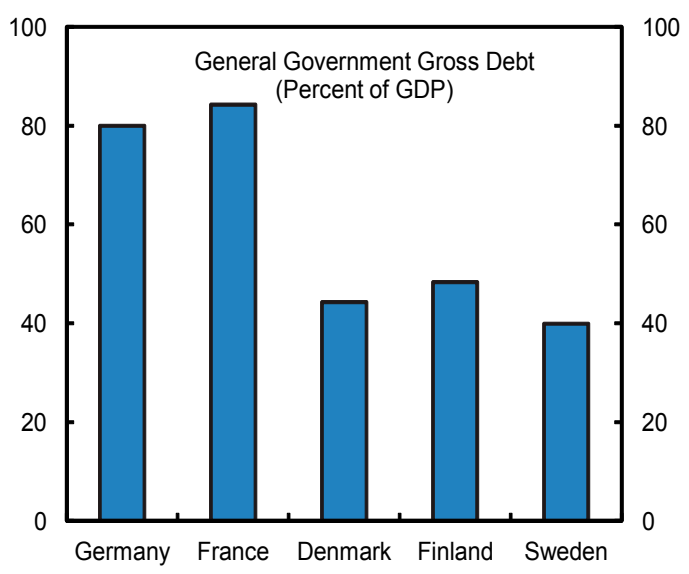

Delivering stimulus through tax cuts and higher spending

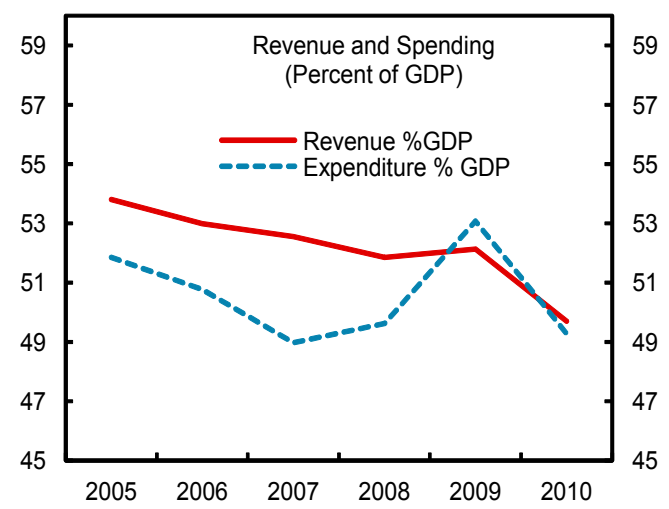

And bond spreads are among the lowest in Europe

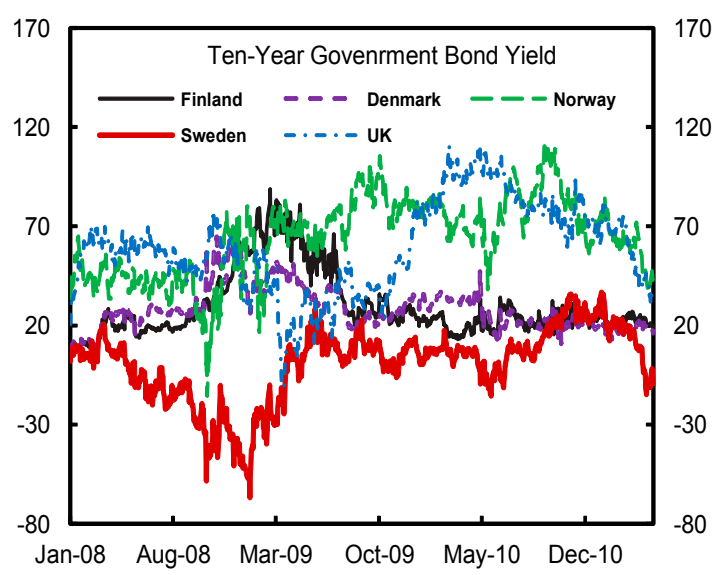

Sources: WEO; Bloomberg; IMF staff calculation. 
Figure 7. Sweden: Performance of the Swedish Banking System, 2007-11

Banks' capital positions have been strengthened...

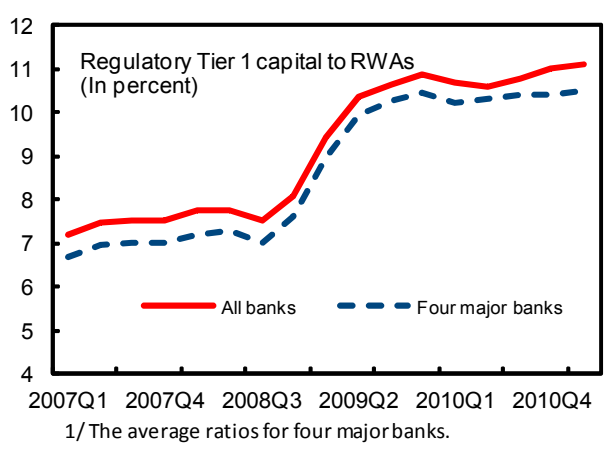

Expected default risks remain low...

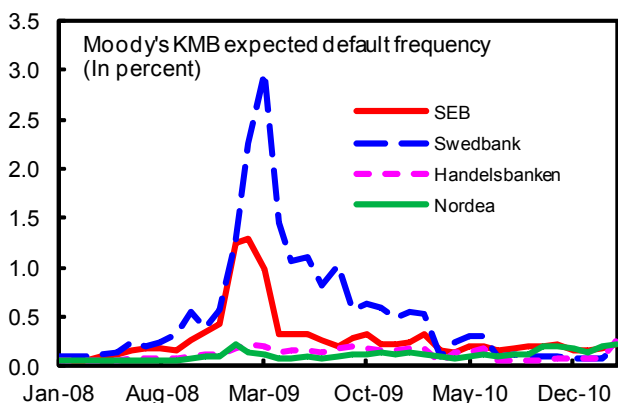

...reflecting the improved situation in the Baltics.

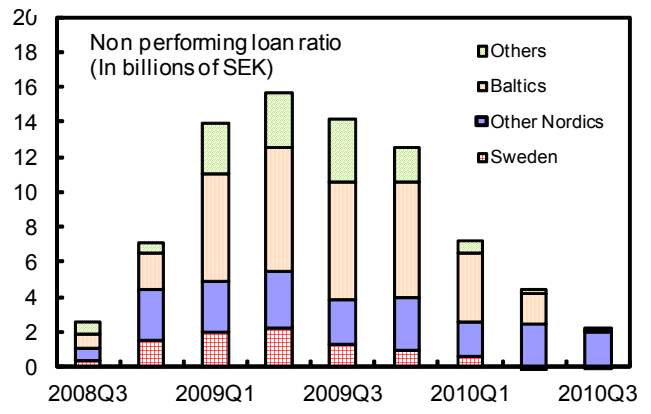

But reliance on market funding has continued to be substantial...

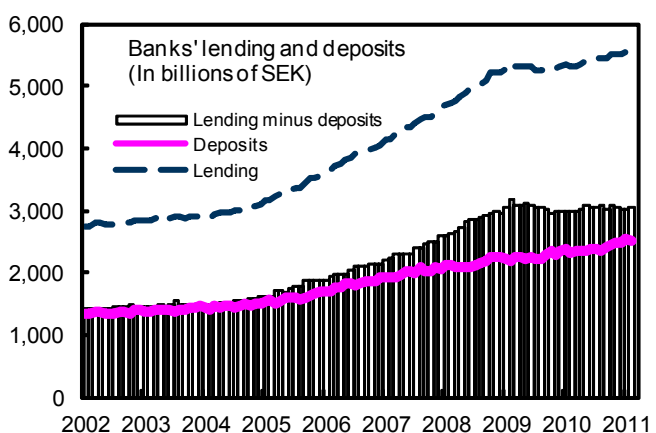

and share prices have recovered

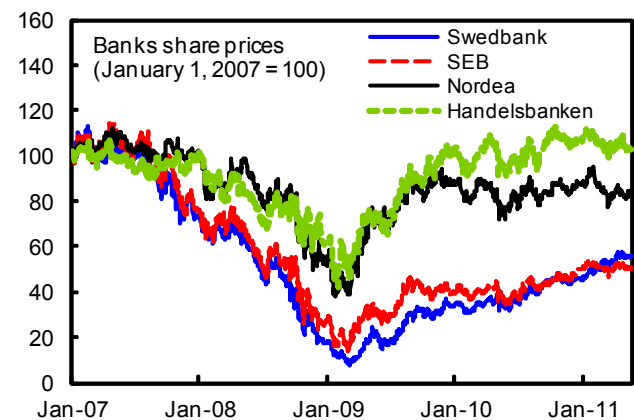

...and non performing loan ratios have stopped rising, as loan losses have declined..

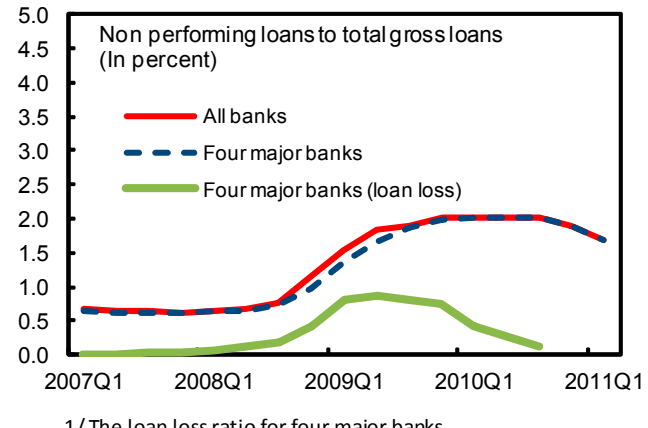

The loan loss ratio for four major banks.

Banks have boosted liquiidty buffers.

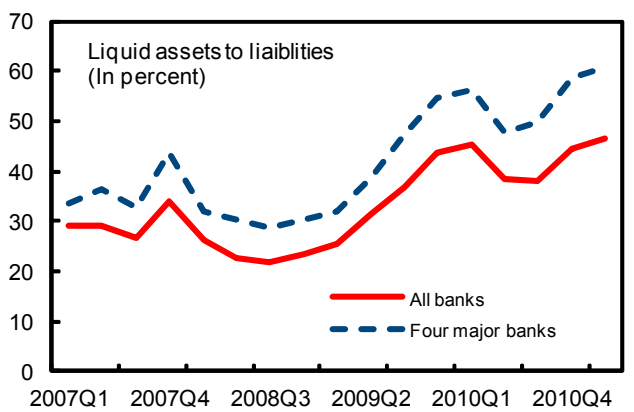

.and it exceeds European peers.

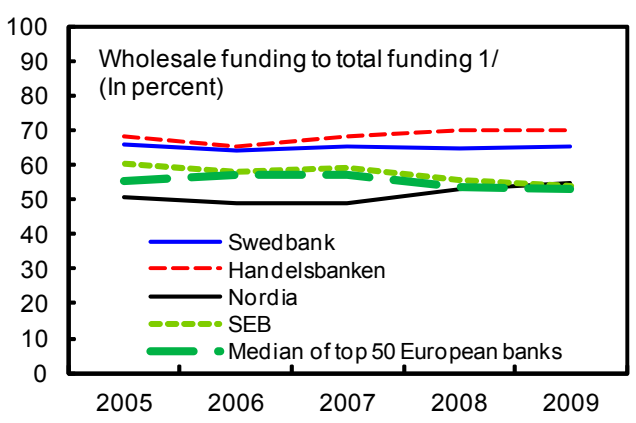

$1 /$ Total funding (excluding derivative) minues customer deposits.

Sources: Thomson Financial/Data Stream; Bloomberg; Banks' Annual Reports; and WEO. 
Figure 8. Sweden: Non-bank Financial Sector, 2007-11
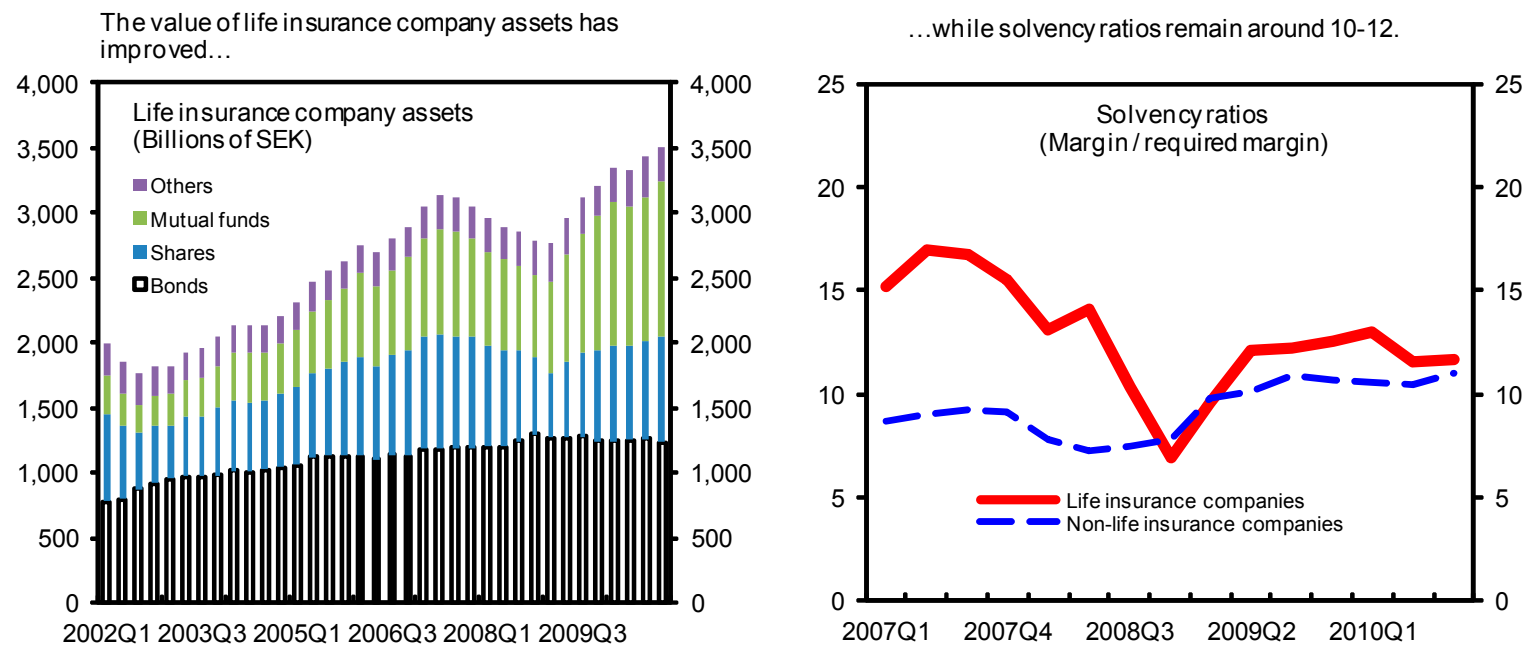

Corporatesector debt has continued to fall...

...while its capacity to cover interest expense s has continued to strengthen.
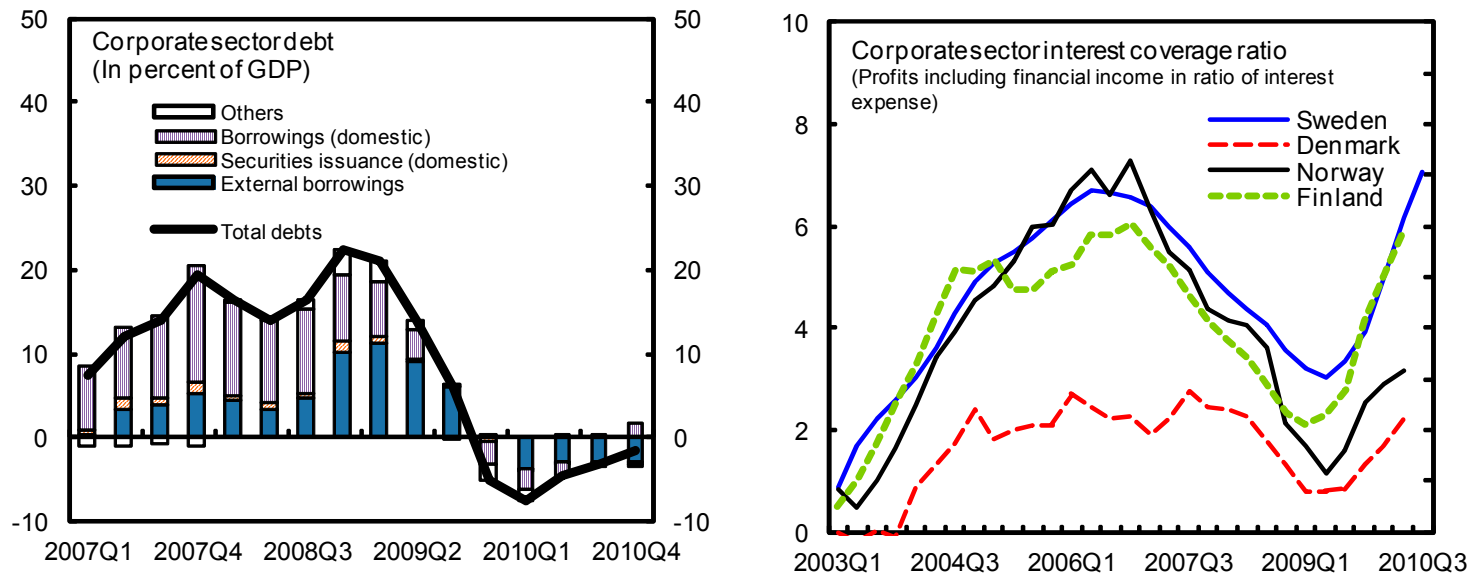

Corporate default risks have fallen, but remain at elevated levels.

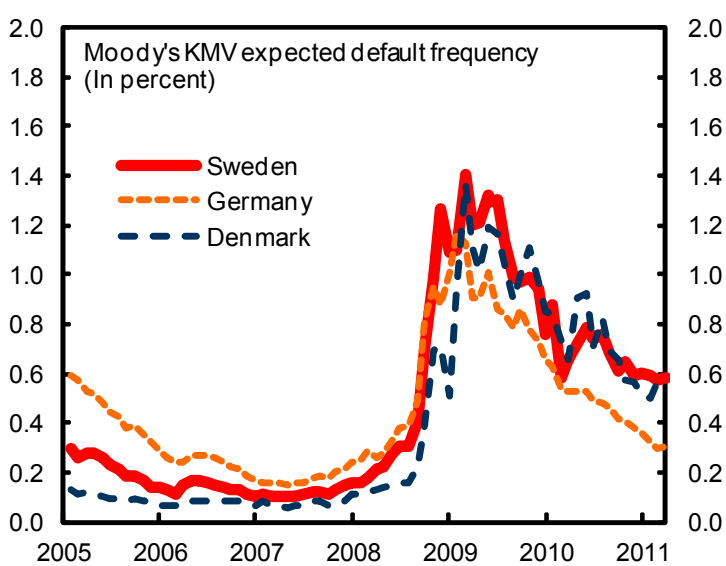

In the household sector, the debt ratio has reached an un precedented level.

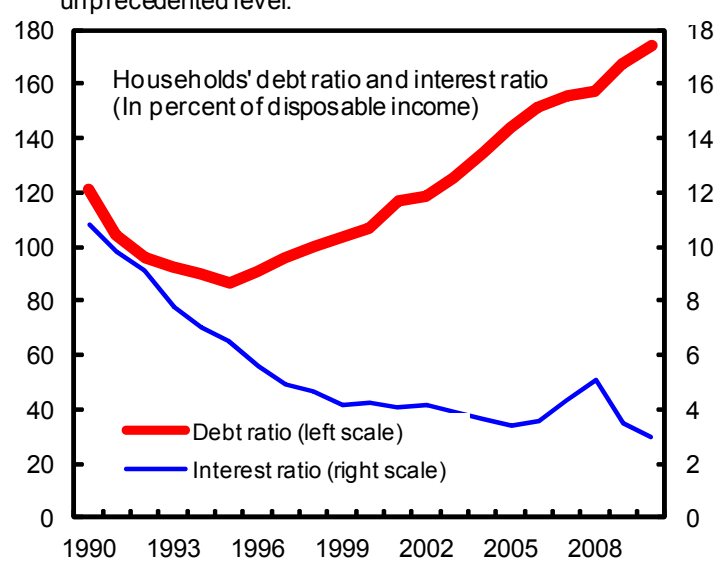

Sources: Riksbank; Statistics Sweden; and Haver. 


\section{ATTACHMENT I-HOW LARGE IS SWEDEN'S OUTPUT GAP? ${ }^{1}$}

1. The Swedish economy has rebounded strongly; real GDP and manufacturing capacity utilization levels were back to pre-crisis levels at end-2010. And asset prices have remained buoyant, for the most part the outcome of the monetary expansion during the crisis. Reflecting these gains, the authorities have begun tightening monetary policy. But unemployment remains high, and fixed investment as a share of GDP remains below precrisis levels. Hence, assessment of the output gap and the rate at which it is closing is key for the Riksbank's ability to calibrate the policy rate path. Failure to sufficiently adjust in advance could result in having to raise interest rates even more sharply, potentially undermining the recovery.

2. Output gap estimates vary among analysts, with the Riksbank at the low end.

\begin{tabular}{|c|c|c|c|c|c|}
\hline \multicolumn{6}{|c|}{ Latest Estimates of Sweden's Output Gap ${ }^{1 /}$} \\
\hline & 2008 & 2009 & 2010 & 2011 & 2012 \\
\hline Riksbank (MP Report, April 2011) $^{2 /}$ & 1.3 & -5.8 & -2.5 & -0.1 & 0.4 \\
\hline Riksbank (MP Report, April 2011) ${ }^{3 /}$ & 0.2 & -7.1 & -3.6 & -0.6 & 0.3 \\
\hline Ministry of Finance (April 2011) & 0.8 & -6.4 & -3.8 & -1.9 & -0.7 \\
\hline National Institute of Economic Research (NIER) & 0.0 & -7.2 & -4.3 & -2.4 & -1.3 \\
\hline OECD & 0.4 & -6.8 & -4.5 & -3.4 & \\
\hline
\end{tabular}

3. This attachment examines the output gap using several methodologies. In summary, staff estimate the output gap at 21/2-31/2 percent of potential GDP in 2010. The recent crisis does not appear to have affected the level of potential output. However, there is some evidence that in the short-term, the equilibrium rate of unemployment may have risen somewhat and the pace of capital formation has slowed. As a result the rate of potential growth has likely slowed, although these effects are unlikely to be permanent. Thus, the output gap is likely to close somewhat gradually.

4. Estimates proposed by staff in 2006-07 for potential output suggest a positive gap in 2010. These estimates anticipated a slowdown in the growth rate of potential output (from 3 percent in 2007 to $1 \frac{1}{2}$ percent in 2012) given that the economy was reaching full capacity in 2006-07-with the growth rate of potential

${ }^{1}$ Prepared by Rita Babihuga (EUR).

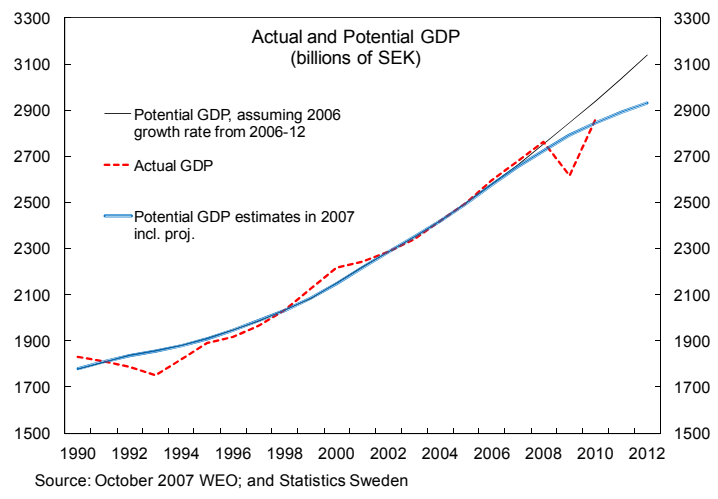


output peaking at 3.3 percent in 2006. Extrapolating this peak growth rate would have implied a negative output gap of close to 3 percent in 2010, with the gap closing substantially from 2009-10.

5. Notwithstanding the projected decline in potential growth, staff estimates of the output gap during the 2009 Article IV Consultation had the following features: (i) they assumed little crisis-induced damage to potential output, given that the source of the shock was external and demand driven; and (ii) they projected a large negative output gap in 2010, reflecting the sharp output contraction and a gradual return to full capacity.

6. These various staff assessments are updated below.

\section{A. Univariate Models}

7. These models present simple techniques for separating long run trends from the cyclical components of GDP. Three univariate methods have been used: the Hodrick-Prescott (HP) filter; the Christiano-Fitzgerald band-pass filter (CF); and the Kalman filter. ${ }^{2}$

8. The different approaches yield varying results, but point to significant spare capacity in the economy. Excluding the CF filter, the output gap is estimated in the order of negative 5-6 percent in 2009 and negative $2 \frac{1}{2}-3 \frac{1}{2}$ percent in 2010.
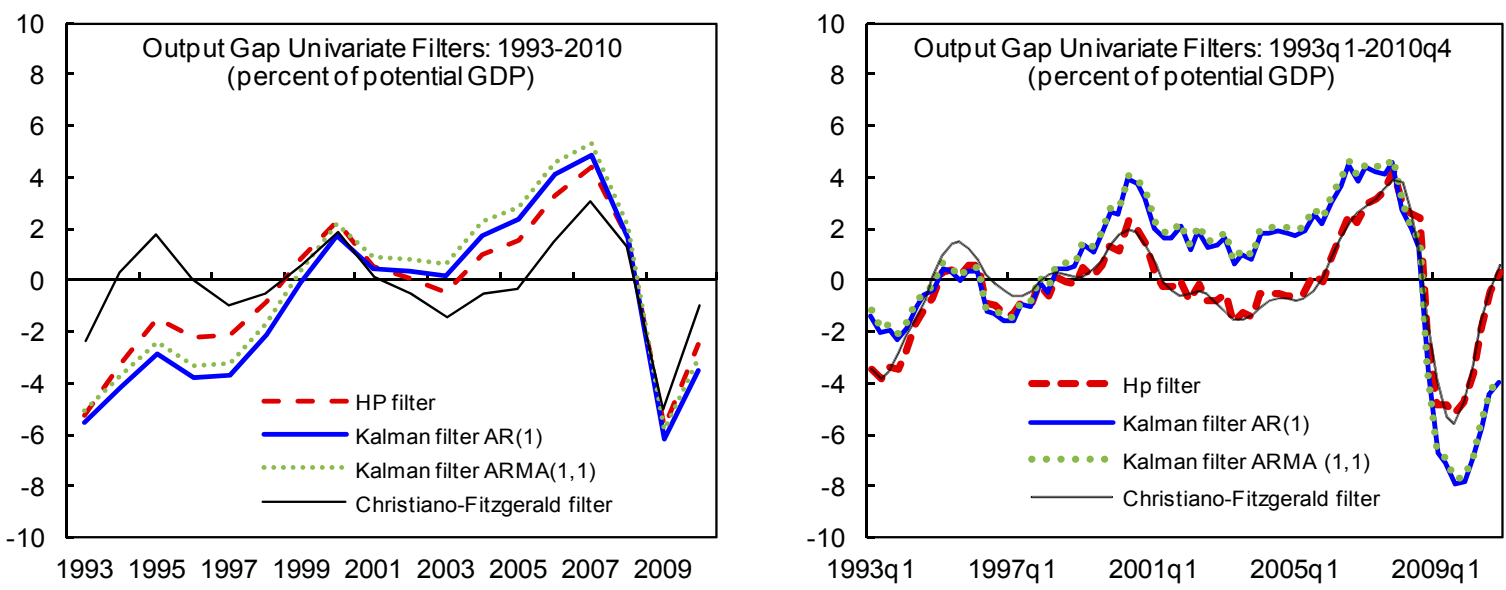

9. Yet, univariate models may not provide robust output gap measures. During economic crises - and large structural changes - univariate methods are particularly prone to bias, given that they rely on historically patterns of observable variables. Moreover, to the extent that the downturn entailed structural changes in the economy as opposed to cyclical phenomenon, the standard smoothing parameters would incorrectly attribute some of the decrease in output to cyclical movements rather than structural decreases in potential

\footnotetext{
${ }^{2}$ These approaches are summarized in the appendix.
} 
output - hence overstating the output gap. The same is true during the upswing - univariate filters are likely to attribute most of the change in actual output to cyclical changesassuming that potential output remains broadly unchanged - thus understating the negative gap in 2010-11.

10. Also, because univariate filters are not model based, their results are not necessarily supported by economic intuition. The HP and CF in particular suffer from end-point bias ${ }^{3}$ and thus may not be suitable for forward looking policy decisions.

\section{B. Growth Accounting-Production Function Approach}

11. In light of these shortcomings, model based approaches are developed below: first, a production function approach; and second: a small macro model. Notably, the latter incorporates additional economic information in order to improve the robustness of output gap measures, as well as correct for some of the standard biases implicit in filtering techniques.

12. Potential output and the output gap are estimated on the basis of Cobb-Douglas production function, and estimates of potential employment, potential capital, and total factor productivity (TFP). As a first step, TFP is derived as a residual of the following two-factor Cobb Douglas production function fitted to time series of the capital stock and labor inputs:

$$
\ln (Y)=\alpha \cdot \ln (W A P * L F P R *(1-u) * H R S)+(1-\alpha) * \ln (K)+\varepsilon
$$

where $Y$ is output, WAP is the working age population, $L F P R$ is the labor participation rate, $u$ is the unemployment rate, HRS is the average hours worked per worker, $K$ is the capital stock, and $\alpha$ is the average labor share over the sample period. TFP, denoted by $\varepsilon$, is derived as the residual of this equation.

13. The decline in output during the recent crisis was largely driven by a contraction in hours worked and total factor productivity, as illustrated in the growth decomposition below. The decline in productivity and hours worked were unprecedented in recent history. Contrary to the experience during the early-1990s crisis, employment and the labor force participation rate played a moderate role in

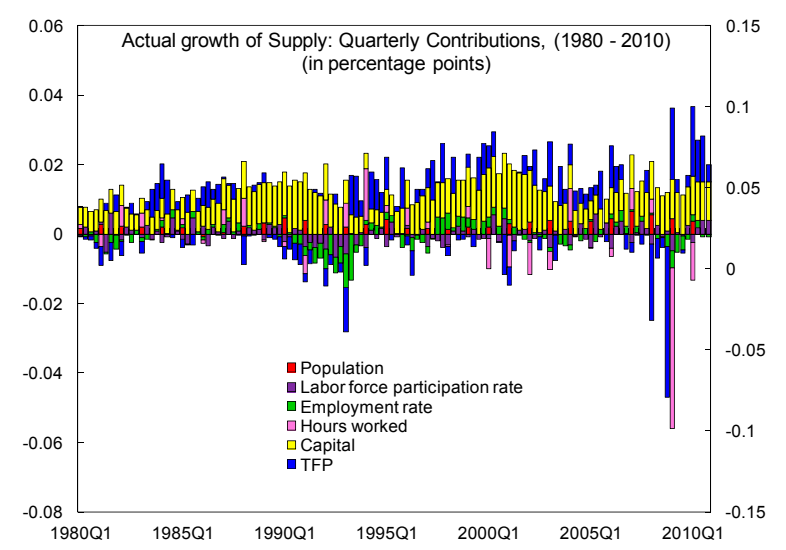

${ }^{3}$ The HP and CF are two sided filters and their assessment of the output gap might change substantially when new data is added. This drawback can be overcome provided that reliable GDP forecasts are available that can be included in the data series. 
output's decline. This reflected labor hoarding on the part of firms, labor market reforms in recent years and the aggressive use of active labor market policies during the crisis to prevent unemployed workers from leaving the labor force.

14. The key question is whether TFP will return to its pre-crisis growth trend. The Riksbank argues that it will not, on the basis that the pre-crisis increase in TFP was driven by cyclical factors, including one-off improvements in technology related to the "dot-com" bubble in the early 2000s. Accordingly, the decline in TFP starting in 2005-06 is part of a non-cyclical secular trend, and growth rates are unlikely to resume their pre-crisis averages.

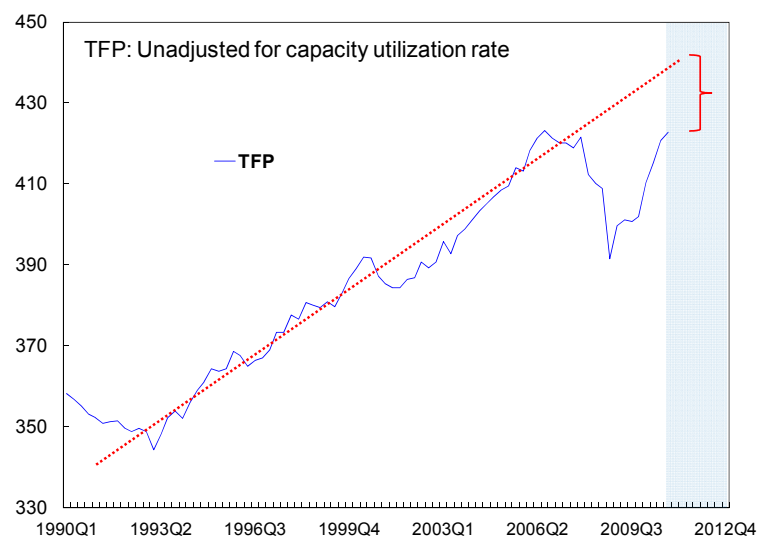

15. Potential output and the output gap are then estimated by extracting cyclical factors from TFP and factor inputs. Trend TFP, and equilibrium values of the other labor input variable (the labor force participation rate, unemployment rate, total hours worked) are derived on the basis of filtering techniques. We estimate the equilibrium values using both $\mathrm{HP}$ and Kalman filters, and correct for end-point bias by including projections to the series to be filtered ${ }^{4}$. Adjustments are made for capacity utilization. ${ }^{5}$

16. The resulting negative output gap estimate, including both TFP and adjusted TFP measures of the gap, is larger than estimates based on the other univariate approaches discussed above. The gap is estimated to have troughed at negative 5-6 percent in 2009 and recovered to negative $3-3 \frac{1}{2}$ percent in 2010. As discussed earlier, the estimates derived on the basis of HP-filtering tend to show a larger negative gap during the downturn, and a smaller negative gap during the recovery. Moreover, the adjusted TFP measures of the output gap point to a slightly larger (negative) output gap than the TFP measure.

\footnotetext{
${ }^{4}$ Two sets of projections for the inputs are generated: (i) by extrapolating the data series on the basis of constant growth rates; and (ii) by assuming a decline in growth rates. Output projections are based on staff's central case scenario in the macro economic framework.

${ }^{5}$ See Appendix.
} 


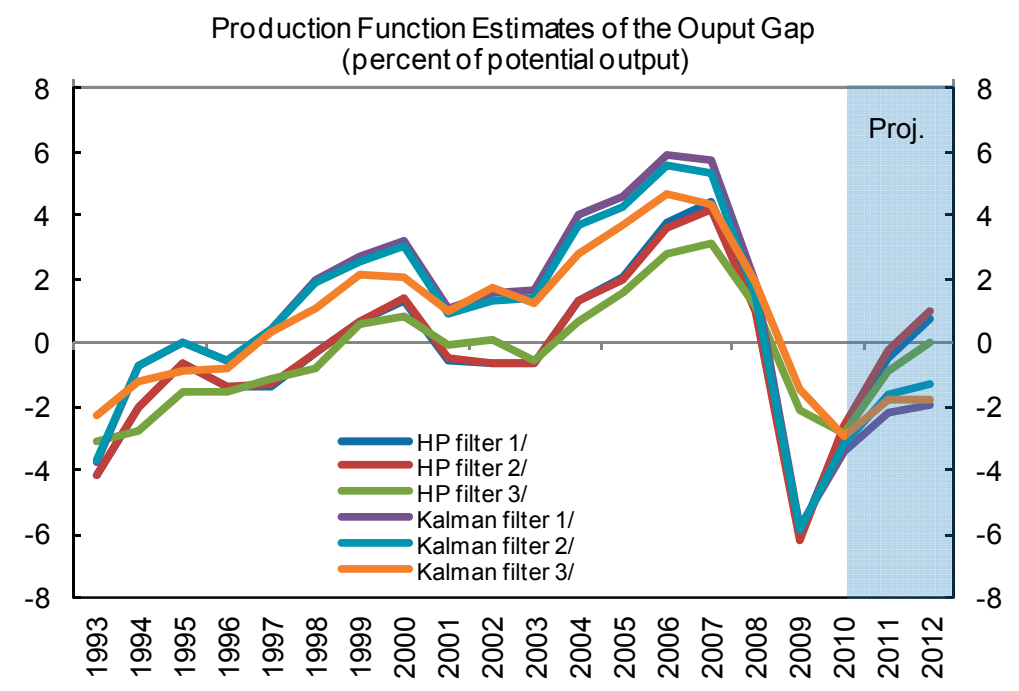

Sources: Euro stat; National In stitute of Economic Research; OECD Analytical Database; Statistics Sweden; and IMF staff estimates.

Notes: Labor inputs are extended by linear extrapolation. The fixed labor share is 0.63 .

$1 /$ Capital stock is extended by linear extrapolation.

2/ Capital stockis adjusted to grow slower than it's pre-crisis path from 2009-2012.

3/ Capital stock is adjusted by capital utilization.

17. Nonetheless, this approach for measuring the output gap entails some potential bias. For example, labor hoarding, which partly explains the behavior of unemployment during the crisis, would cause adjusted TFP to be underestimated. Correspondingly, potential output and the size of the (negative) output gap would also be underestimated. Another source of bias is the manufacturing sector capacity utilization rate. If the capacity utilization rate of the nonmanufacturing sector is less volatile than that of the manufacturing sector-for example, the retail sector might find it more difficult to adjust store hours when demand declines - adjusted TFP would be overestimated. HP-filtered series would thus overestimate trend TFP, possibly resulting in overestimation of the size of the output gap.

\section{Multivariate Modeling Approach}

18. The multivariate filtering (MV) approach for estimating potential output and the output gap incorporates relevant empirical relationships between actual and potential output, unemployment, core inflation and capacity utilization in manufacturing within the framework of a small macroeconomic model. This approach allows the estimated growth of potential output to vary with an array of recent information - inflation, unemployment and capacity utilization - while at the same time taking into account the more stable trends evident in long-term series. The estimation is done by regularized maximum likelihood, allowing prior distributions to be defined where possible, and the "data to speak" where relevant. The model is applied to quarterly data for Sweden from 1996Q2-2010Q4. This sample period is dictated by the availability of data. 
19. The results depend on well-chosen priors. The most important of these are the parameter governing how fast potential growth returns to steady state following shocks, and the relative frequencies of demand and supply shocks. A given change in actual GDP may reflect a fluctuation of actual GDP around a stable potential GDP path - that is, reflecting a demand shock - or a change in potential GDP — that is, reflecting a supply shock. The interpretation of observed fluctuations in GDP in terms of the underlying shocks clearly has strong implications for the resulting view of potential GDP. In particular, the prior values one assigns on the relative variance of demand and supply shocks have a large impact on the estimates of potential output resulting from the crisis.

20. Staff's prior is that demand shocks are the primary source of real GDP fluctuations in Sweden, consistent with historical economic patterns. Sweden's economy is highly export oriented, with output growth highly correlated with external demand. These patterns were evident during the recent crisis, suggesting an externally driven demand shock. Hence, a priori, distributions in the case of Sweden should emphasize demand shocks as the source of

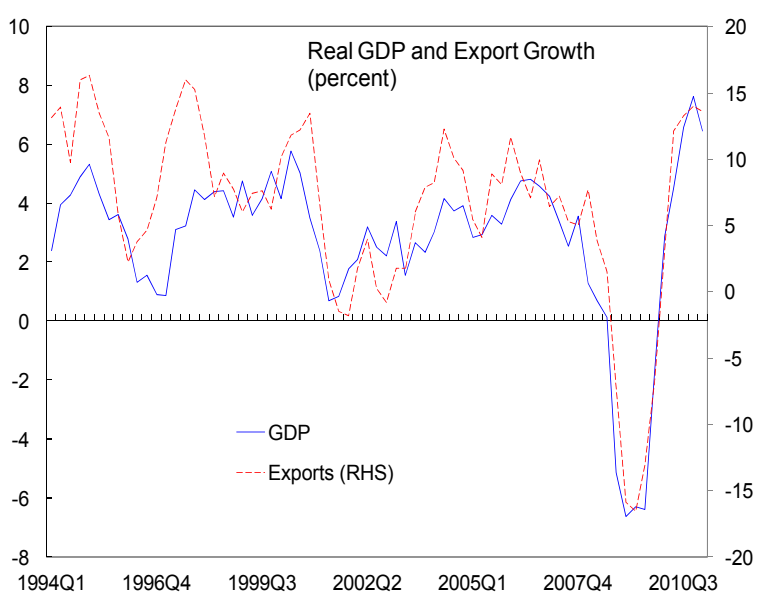
fluctuations in actual GDP_as opposed to supply shocks.

21. Yet, there is reason to believe that potential output growth has fluctuated during 2008-10. In particular, fixed investment fell by record proportions while unemployment remains above pre-crisis averages. While the fall in fixed investment is viewed as temporary, its recovery will take time. Similarly, ongoing labor market reforms are expected to continue bringing the unemployment rate down in coming years. Hence, the parameter governing how fast potential output returns to steady state-which ranges from 0.1 (fast) to 1 (slow) - is set at a moderate 0.4 , reflecting some hysteresis effects of the recession.
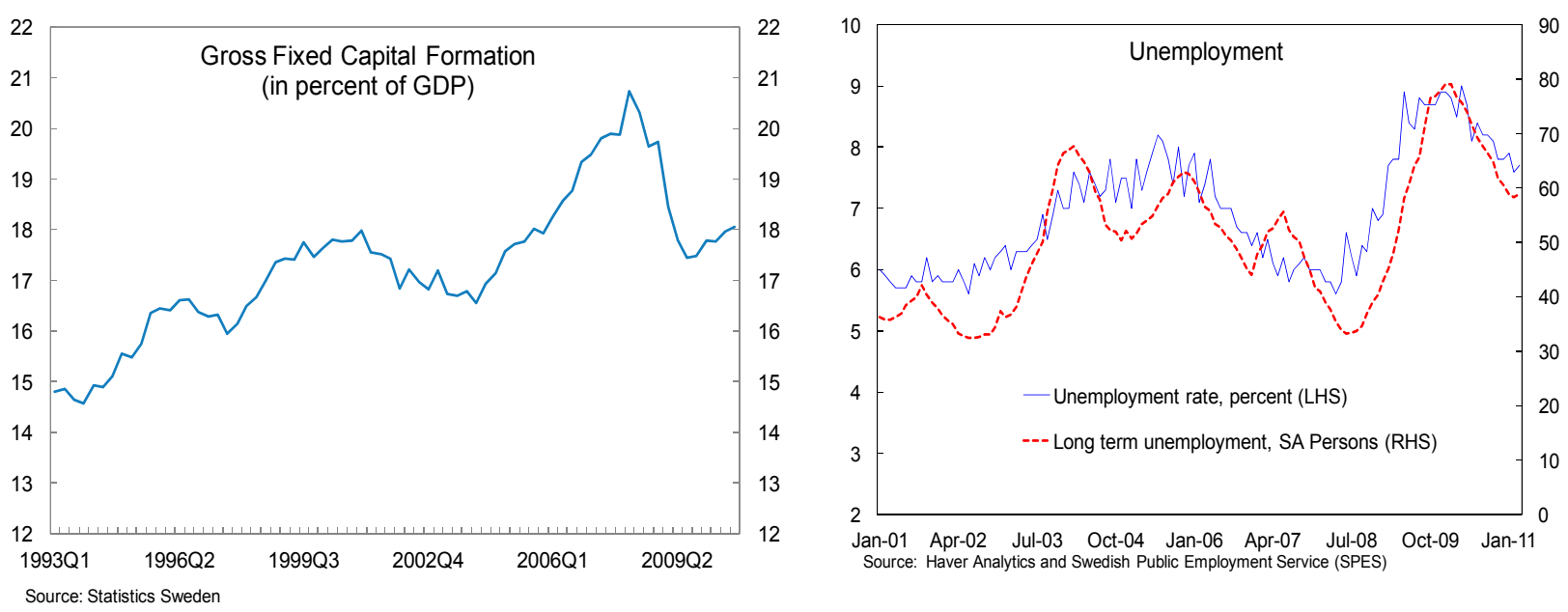
22. We consider two main scenarios. First, the authorities' labor market reforms succeed in lowering equilibrium unemployment down to 5 percent. Alternatively, we consider a "no policy" scenario in which the equilibrium unemployment rate remains at 6 percent.

23. Results from the multivariate filter model are summarized in the appendix figures. They suggest marginal differences in the output gap between the two scenarios, indicating the following:

- Output gap and inflation. The estimated output gap dropped sharply during the 2008-09 recession to a trough of about minus 7 percent in 2009Q3, but by 2010Q4, it had swung back up to a central estimate of minus 2 percent. Inflation broadly evolved as expected given the estimated output gap. Core inflation declined during two distinct periods (2003Q1-2004Q3; and 2008Q4-2010Q4), dipping below the 2 percent target.

- Potential Output. Potential growth declined from 2 percent in 2008 to 1.3 percent, from a historical average of 3 percent (1997-2007); however, it rose by $1 \frac{1}{2}$ percent in 2010 . Actual and potential output, appear correlated but as expected the estimated evolution of

\begin{tabular}{lccc}
\hline & Real GDP & Potential Output & Output gap \\
\hline $1997-2004$ & 3.2 & 3.0 & -0.3 \\
$2004-07$ & 3.7 & 2.8 & 1.2 \\
2008 & 0.5 & 2.0 & -0.1 \\
2009 & -5.3 & 1.3 & -6.8 \\
2010 & 5.4 & 1.5 & -3.0 \\
\hline
\end{tabular}
potential is relatively smooth, such that the gap accounts for most of the short term fluctuations in GDP. Moreover, the peaks and troughs of estimated potential growth lag actual GDP growth.

- Unemployment rate and NAIRU. The MV filter estimates show a slight increase in the NAIRU from 2002-06, followed by a slight decline in the period ahead of the crisis. The model indicates a small rise in the NAIRU in the period 2008-10 (of some $1 / 2$ of a percentage point) in the main scenario-perhaps reflecting lagged labor-market effects of the steep increase in actual

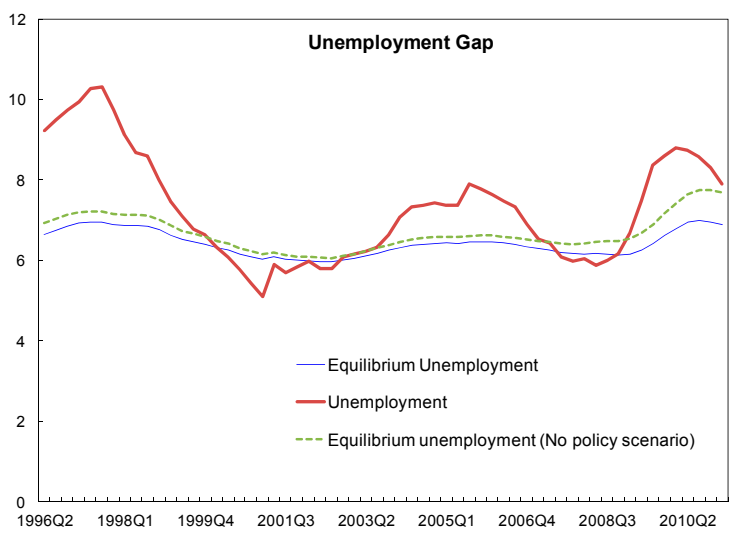
unemployment in 2008-09). Also given the high labor share of income, 67 percent, the persistent unemployment gap is interpreted as a decline in potential output. In the alternative scenario, where steady state unemployment is 6 percent assuming no policies, the equilibrium unemployment rate rises by about 1 percentage point. 


\section{Is There Corroborative Evidence of Rising Equilibrium Unemployment?}

24. Unemployment has lagged the recovery and may have spilled over into the equilibrium rate. We look at evidence from the Beveridge Curve to verify whether this is true. The Beveridge curve $(\mathrm{BC})$, depicts a negative relationship between vacancies and unemployment and serves as a simple representation of how efficient labor markets are in terms of matching unemployed workers to available job openings in the aggregate economy. The position of the economy on the curve is an indicator of the state of the labor marketi.e., a high level of vacancies and a low level of unemployment imply a tight labor market. An outward shift in the curve can occur as a result of structural shifts in the economy, which affect the matching efficiency of the labor market.

25. The outward shift in the Beveridge curve from 2001-07 is puzzling given the wide ranging labor market reforms during the past decade. In particular, tax reductions as well as reform of the unemployment insurance and sick leave benefits system, together with increased coordination of wage formation should have lowered equilibrium unemployment in recent years by increasing the labor force participation rate. Hence, an inward shift would be more intuitive. One explanation, for the counter-intuitive outward shift could be that recent reforms have temporarily increased matching problems by introducing into the labor supply lower skilled workers (coming out of the sickness benefits system) who have been absent from the work force for a long period of time and lack the requisite skills for the current economy. A further possibility is cyclical - that the position of the curve shifts out during upswings, as followed the dot.com crash (Pissarides).

26. As expected, and borne out by historical evidence, there were movements along the Beveridge Curve (January 2007 to January 2009), as the Swedish economy entered the recent recession. Unemployment rose sharply and vacancy rates fell, causing the equilibrium in the labor market to move downwards along the curve.

Nonetheless, the curve appears to have shifted outwards during the crisis, signaling deterioration in the labor market's matching efficiency. This visible change in the curve coincides with similar evidence from the MV filter model pointing to a slight increase in the NAIRU during 2008-10, suggesting that the labor market could have temporarily

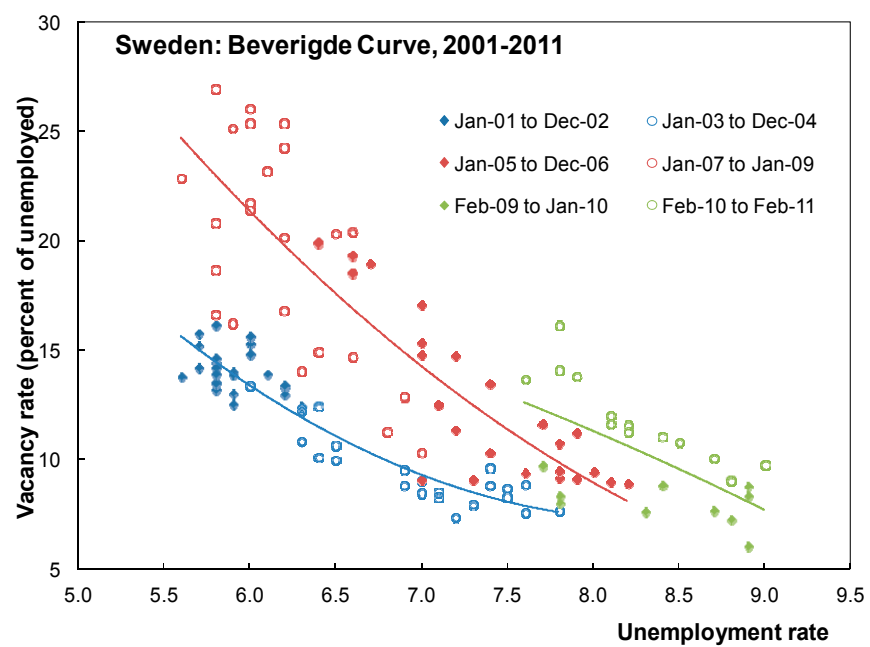
moved to a new equilibrium. 


\section{E. Conclusions}

27. The empirical approaches considered in this attachment consistently point to a negative output gap in 2010-11, but they differ on the extent of economic slack. The three standard methodologies used in the analysis suggest that there continued to be significant spare capacity in the Swedish economy at end-2010. Specifically, the output gap in 2010 is estimated to have been within the range of negative $2 \frac{1}{2}-3 \frac{1}{2}$ percent. The relative width of the range reflects the degree of uncertainty about the effect of the financial crisis on potential output growth. Moreover, the methodologies differ on the speed of adjustment since end2010, suggesting the output gap is within the range of negative $1 / 2-2$ percent in 2011 . Lastly, the model based multivariate filter suggests there has been an increase in the equilibrium rate of unemployment, with the cyclical unemployment spilling over into the underlying rate of unemployment - and this increase is in the range of $1 / 2$ to 1 percent depending on the extent to which ongoing labor market reforms are effective.

\begin{tabular}{|c|c|c|c|c|c|}
\hline \multicolumn{6}{|c|}{$\begin{array}{c}\text { Summary of Results } \\
\text { Output gap (in } \% \text { of potential output) }\end{array}$} \\
\hline & 2008 & 2009 & 2010 & 2011 & 2012 \\
\hline \multicolumn{6}{|l|}{ Univariate filters: } \\
\hline HP filter & 1.6 & -5.7 & -2.4 & -0.3 & 0.7 \\
\hline Kalman filter & 1.6 & -6.2 & -3.5 & -1.9 & -1.5 \\
\hline \multicolumn{6}{|l|}{ Production function: } \\
\hline HP filter & 1.4 & -6.0 & -2.7 & -0.5 & 0.7 \\
\hline Kalman filter & 1.5 & -5.9 & -3.1 & -1.6 & -1.3 \\
\hline Multivariate filter ${ }^{1 /}$ & -0.1 & -6.8 & -3.0 & $\cdots$ & $\ldots$ \\
\hline
\end{tabular}




\section{Appendix}

\section{Multivariate Filter Results}

\section{Policy Scenario: Steady state unemployment $=5$ percent}

Output Gap (+/- 2 std. deviations)

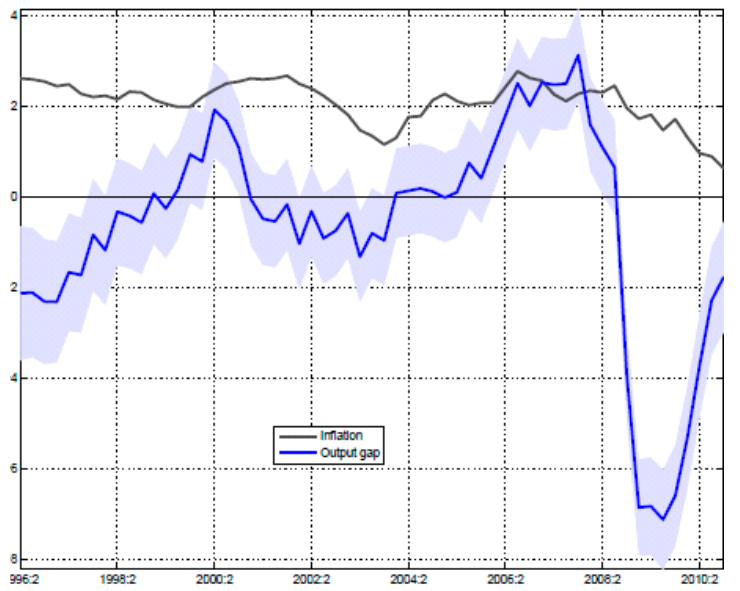

Actual and Potential Output Growth (y/y) +/- 2 std deviations

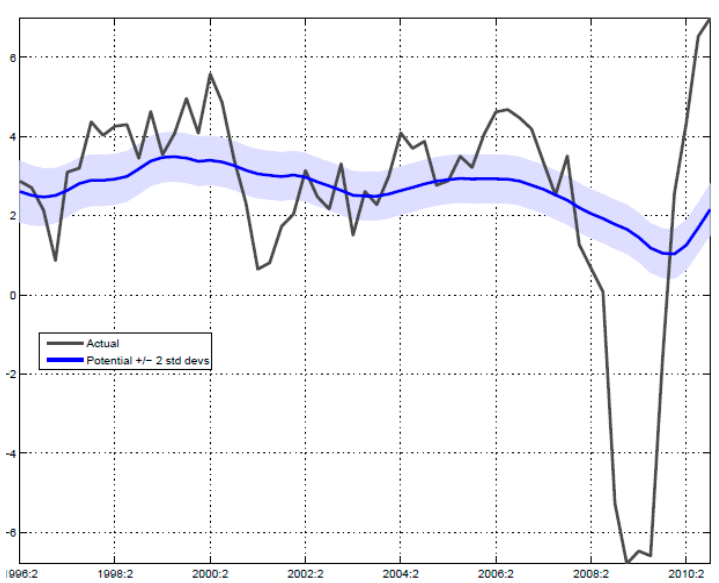

No Policy Scenario: Steady state unemployment $=6$ percent
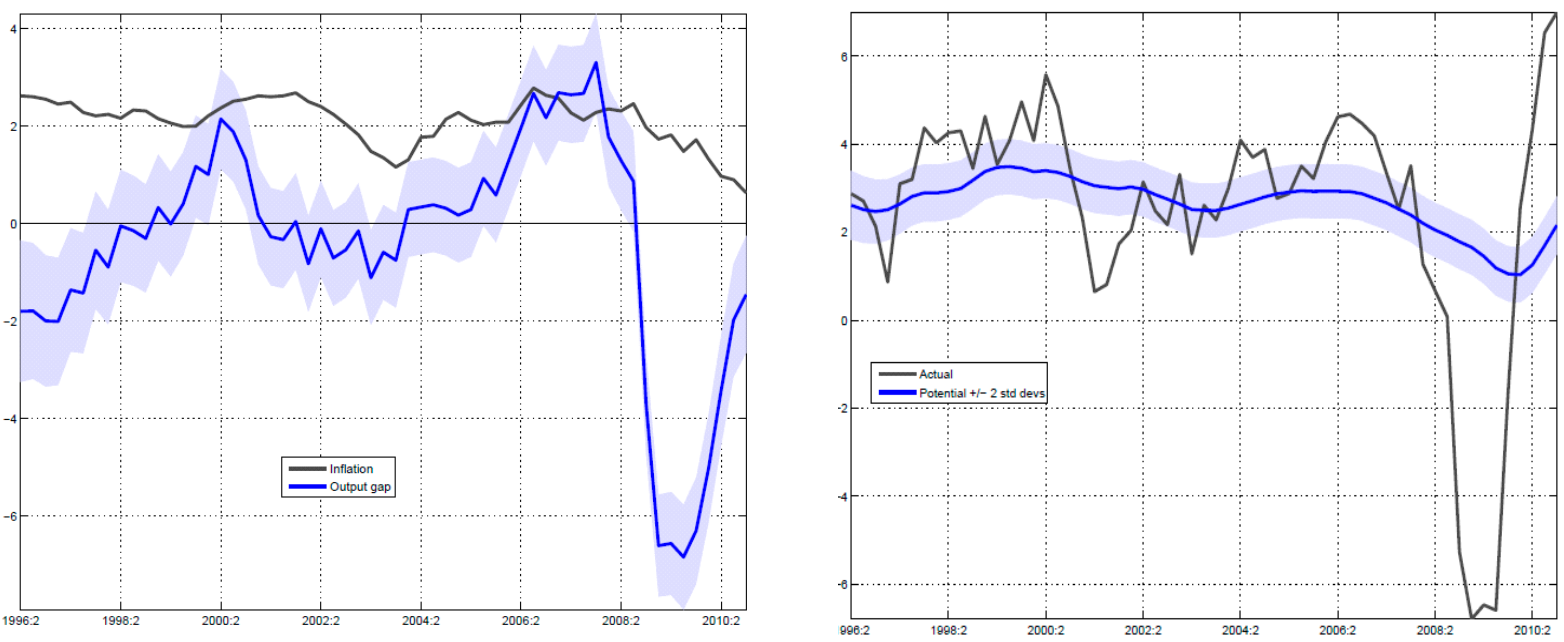


\section{Univariate Filters}

\section{Hp filter}

The HP filter calculates potential output by minimizing both the fluctuations of the cycle and the trend, subject to a restriction on the variation of potential output. The restriction, lambda, determines to what extent variability in the trend relative to the cycle is allowed for. A higher lambda indicates a larger importance of cyclical shocks and yields a smoother trend/potential output. The standard values for lambda, for an advanced economy like Sweden's, are 1600 and 100 for quarterly and annual data, respectively ${ }^{6}$.

\section{Christiano-Fitzgerald Filter}

Band pass filters like the CF are designed to eliminate high and low frequency movements in the data using a two-sided symmetric moving average. The CF is non-stationary, asymmetric and depends on the time series properties of the underlying data. Despite its also remaining prone to end-point bias, its revision properties are slightly better than the HP. Swedish GDP is integrated with an order of 1 , so the band pass filter is estimated on a stationary GDP series.

\section{Kalman Filter}

We estimate an unobserved components model based on a simple Kalman filter. The model assumes two specifications: output follows an AR1 process and an ARMA process, while potential output is modeled as a random walk with drift. This approach suggests a larger output gap than the HP filter. One possible explanation for this lies in the fact that to a greater extent than the HP filter, the Kalman model assumes the growth rate of potential GDP has not been constant over time. Because the Kalman model treats the growth rate of potential output as time varying, it is better able to extract cyclical fluctuations from the data.

\footnotetext{
${ }^{6}$ Standard values of lambda have been calibrated based on the US economy.
} 


\section{Production Function Approach}

The main empirical problem with equation (1) described earlier, is that any results are potentially biased, given that capital and labor utilization are unobserved. Without controlling for the intensity of resource utilization, the TFP residual is likely polluted by these changes. As illustrated in the growth decomposition chart above, output fluctuations have historically been driven to a great extent by changes in productivity. This is partly due to the fact that the capital input to production, essentially relies on the total capital stock, not the flow of services actually provided by this stock at any given point in time.

One solution to this potential bias is to control for factor utilization by adjusting the capital stock to better reflect the intensity of its use in the production process. This is done by using capacity utilization to derive a proxy for the flow of capital services. Labor utilization is assumed to be constant.

The original production function equation is adjusted as follows and fitted to the data to derive capacity utilization rate-adjusted TFP (adjusted TFP):

$\ln (Y)=\alpha \cdot \ln (W A P * L F P R *(1-u) * H R S)+(1-\alpha) * \ln (c u . K)+\varepsilon$

where $c u$ is the capacity utilization rate and $\varepsilon$ is adjusted TFP.

Adjusted TFP falls less than TFP during 2008-09 (text chart). The text chart shows TFP and adjusted TFP derived from fitting the two equations above. Since fluctuations of both labor inputs and capacity utilization rates have been controlled for in the adjusted TFP series, the decline likely reflects factors whose effects are lasting even when adjusted TFP resumes its trend growth. These factors could include, among others, a higher cost of capital during the global financial crisis, and a permanent shift of demand away from sectors that enjoyed high productivity growth, for instance manufacturing ${ }^{7}$. There is some evidence of a resource shift away from the tradable to the non-tradable sector. As expected, the manufacturing sector suffered the bulk of job losses during the crisis - and, data show that employment during the recovery has been equally uneven at the expense of the manufacturing sector.

\footnotetext{
${ }^{7}$ The recovery in employment and investment has been uneven, with the manufacturing sector in particular, lagging.
} 

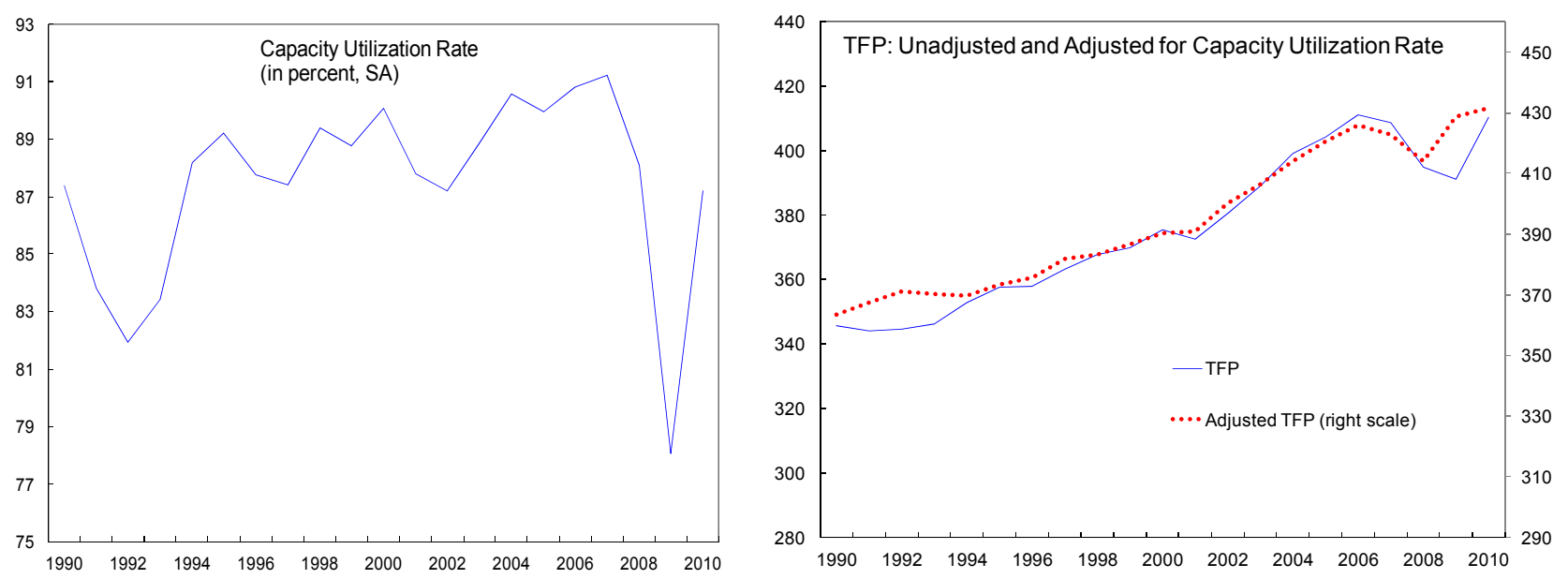

28. The components (figure) suggest a decline in potential output growth during 2008-09, and a slight increase in 2010. After rising by 0.9 percent per year on average during 2000-08, the equilibrium labor participation rate declined during the recession, though not nearly to the same degree as during the 1990 s.

29. Equilibrium hours worked per employee fell during the recession. Given the sharp decline in measured hours worked, the Kalman filter in particular - which allows for fluctuations in the trend variable - shows a larger decline in equilibrium hours as well. By construction, adjusted TFP should not be affected by cyclical factors - a smoothed adjusted TFP series should be a good representation of trend TFP for potential output. 
Sweden: Equilibrium Aggregate Inputs and Output Gaps, 1985-2011
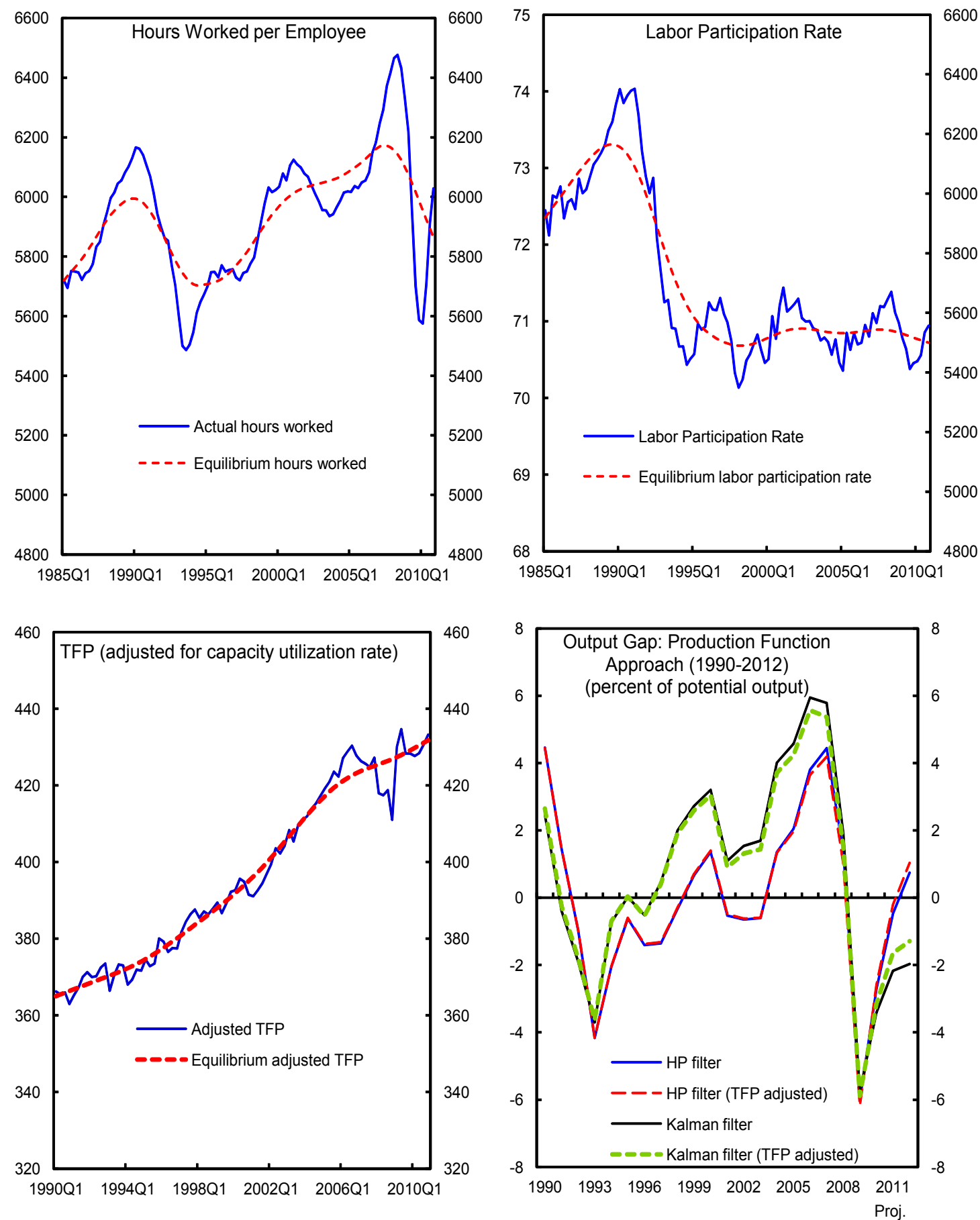

Source: IMF staff estimates. 


\section{Multivariate Model}

The model, detailed in Benes et. al., (2010) is built around three gaps - the output gap, unemployment gap and capacity utilization gap — and three identifying equations as follows:

An inflation equation relating core inflation with the level $\left(y_{t}\right)$ and the change $\left(y_{t}-y_{t-1}\right)$ in the output gap takes the form:

$$
\pi 4_{t}=\pi 4_{t-1}+\beta y_{t}+\Omega\left(y_{t}-y_{t-1}\right)+\varepsilon_{t}^{\pi^{4}}
$$

Based on Okun's law defining the relationship between the unemployment rate and the output gap, a dynamic unemployment equation links the unemployment gap to the output gap, also taking into account the lagged effect of changes in output on unemployment:

$$
u_{t}=\Phi_{1} u_{t-1}+\Phi_{2} y_{t}+\varepsilon_{t}^{u}
$$

The model assumes there is important information in capacity utilization to improve the estimates of potential output and the output gap, and specifies a capacity utilization equation similar to the Okun law relationship:

$$
c_{t}=\kappa_{1} c_{t-1}+\kappa_{2} y_{t}+\varepsilon_{t}^{c}
$$

Given the three identifying equations, equilibrium variables are assumed to evolve dynamically as follows. A stochastic process including transitory, level shocks and more persistent shocks determines the evolution of equilibrium unemployment $\left(\bar{U}_{t}\right)$, with the NAIRU equation specified as follows:

$$
\bar{U}_{t}=\bar{U}_{t-1}+G_{t}^{\bar{U}}-\frac{\omega}{100} y_{t-1}-\frac{\lambda}{100}\left(\bar{U}_{t-1}-U^{S S}\right)+\varepsilon_{t}^{\bar{U}}
$$

with persistent shocks to the NAIRU $\left(G_{t}^{\bar{U}}\right)$ following an autoregressive process:

$$
G_{t}^{\bar{U}}=(1-\alpha) G_{t-1}^{\bar{U}}+\varepsilon_{t}^{G^{\bar{U}}}
$$

Potential output is modeled as a function of the underlying trend growth rate of potential output $\left(G_{t}^{\bar{Y}}\right)$ and on changes in the NAIRU:

$\bar{Y}_{t}=\bar{Y}_{t-1}-\theta\left(\bar{U}_{t}-\bar{U}_{t-1}\right)-\frac{(1-\theta)\left(\bar{U}_{t-1}-\bar{U}_{t-20}\right)}{19}+\frac{G_{t}^{\bar{Y}}}{4}+\varepsilon_{t}^{\bar{Y}}$

$\theta$ is the labor share of income in a Cobb-Douglas production function, and $G_{t}^{\bar{Y}}$ is output trend growth, with: 


$$
G_{t}^{\bar{Y}}=\tau G_{S S}^{\bar{Y}}+(1-\tau) G_{t-1}^{\bar{Y}}+\varepsilon_{t}^{G^{\bar{Y}}}
$$

where

$G_{S S}^{\bar{Y}}$ is the steady state growth rate of output. Moreover, potential output trend growth $G_{t}^{\bar{Y}}$ is not constar

Trend capacity utilization, $\bar{C}_{t}$ is modeled as follows:

$$
\bar{C}_{t}=\bar{C}_{t-1}+G_{t}^{\bar{C}}+\varepsilon_{t}^{\bar{C}}
$$

and growth in trend capacity utilization also follows an autoregressive process:

$$
G_{t}^{\bar{C}}=(1-\delta) G_{t-1}^{\bar{C}}+\varepsilon_{t}^{G^{\bar{C}}}
$$

Maximum likelihood estimation is infeasible, given the many unidentified parameters hence the full model is estimated using a regularized maximum likelihood. This method can be interpreted as a simple Bayesian technique requiring the user to define prior distributions of the parameters. While this can improve the estimation procedure by preventing parameters from wandering into nonsensical territory, the choice of priors also has a non-negligible impact on the resulting final estimates given that the data are uninformative about certain parameters.

In addition to the prior distributions of the parameters, values for the labor share $\theta$, steady state unemployment $U^{S S}$ and potential GDP $G_{S S}^{Y}$ growth rates need to be provided and were set at $0.63 ; 5.1$ and 6 percent (in a policy and alternative scenario); and $2 \frac{1}{2}$ percent, respectively. While these steady state values matter conceptually given that the endogenous estimates converge to these exogenously given values in the long term, from a practical point of view the dynamics over the time horizon of interest are relatively little affected by the choice of steady state values. 


\section{References}

Benes, J et. al., 2010, “Estimating Potential Output with a Multivariate Filter," IMF Working Paper, No. 10/285.

Carlsson, M., Julián Messina and O. N. Skans, 2011, "Wage Adjustment and Productivity Shocks,” Riksbank Working Paper No. 253.

Christiano, L. J. and T. J. Fitzgerald, 2003, “The Band Pass Filter,” International Economic Review, Vol.44, No. 2.

National Institute of Economic Research (KI), Wage Formation in Sweden 2011.

Nyman, Christina, 2010. “An Indicator of Resource Utilization,” Riksbank Economic Commentaries, No. 4, October 2010.

Orphanides, Athanasios. 2002. "Monetary Policy Rules and the Great Inflation." American Economic Review, Papers and Proceedings 92 (2, May) pp. 115-120.

Riksbank, Monetary Policy Report, October 2010. 


\section{ATtaChMENT II-The SWEDISH SOVEREIGN ${ }^{1}$}

1. Markets and the Swedish Fiscal Policy Council (FPC) are confident of the strength of the Swedish Sovereign. ${ }^{2}$ Are they correct? This attachment assesses this by using a comprehensive framework. ${ }^{3}$ It concludes that while all conventional indicators flash green, contingent liabilities in the financial sector will need to be contained and carefully monitored to maintain this strength.

\section{A. The Baseline}

2. This part of the assessment is based on indicators of solvency risks, current deficit and debt levels, and projected growth-adjusted interest rate on public debt. Indicators of long-term budget pressures associated with demographics, such as projected changes in health care and pension expenditures and risks to fiscal sustainability stemming from sovereign asset and liability composition and financing requirements are considered alongside. ${ }^{4}$

3. The indicators for Sweden are compared with group averages for advanced economies and European countries. These are also assessed against thresholds that, when exceeded, indicates a higher risk of fiscal stress as estimated in Baldacci et. al., (2011b). See Appendix I for a detailed description of all variables, their respective stress thresholds and their signaling power.

4. For advanced countries, fiscal risks currently remain elevated and well above pre-crisis levels (Figure 1). Of particular concern are the high solvency risks related to fiscal fundamentals and aging related long-term budget pressures, as well as record-high budget financing needs. Advanced and European countries currently exceed the thresholds on public debt, the cyclically adjusted primary balance, gross financing needs and long-term health spending.

5. In the case of Sweden, the fiscal indicators showed a marked deterioration in the early 1990s as a result of the Nordic banking and economic crisis. The deterioration of the fiscal position was faster than anticipated and only partially related to cyclical factors. The authorities pursued fiscal policies to support activity and employment beyond providing significant budget support to banks. The increase in unemployment was large and persistent and so the overall fiscal balance deteriorated significantly (16 percentage points of GDP over

\footnotetext{
${ }^{1}$ Prepared by Borja Gracia (FAD).

${ }^{2}$ Swedish Fiscal Policy Council (2011)

${ }^{3}$ See Cottarelli (2011).

${ }^{4}$ Appendix I present data definitions and sources from Baldacci et. al., (2011a).
} 
1990-93) with only half of the deterioration attributed to cyclical factors. ${ }^{5}$ Although Sweden started the crisis with low debt and fiscal deficits, the situation deteriorated rapidly to the point where the focus of attention shifted from counter-cyclical fiscal policies to fiscal sustainability.

6. This is confirmed by the fiscal indicators in Figure 1. Gross public debt was above the threshold until the late 1990s and the cyclically adjusted primary balance reached -8 percent of GDP by 1993, generating very large financing needs during that period. On the other hand, long-term fiscal pressures at the time did not seem to be particularly worrisome emphasizing the fact that in its fiscal dimension, following corrective measures, the early 1990s crisis was a liquidity rather than a solvency crisis.

7. In the more recent global crisis, Sweden's experience was radically different from advanced countries. In contrast to the deterioration in the fiscal stance and public debt elsewhere, the cyclically adjusted primary balance did not deteriorate, financing needs remain low and public debt increased marginally in 2009 returning to a negative trend in 2010. Thanks to the welfare and pension reform of the past two decades, Sweden has also addressed some of the long-term fiscal pressures. In all long-term indicators Sweden does better than all group averages and the median, particularly in health spending and fertility rate (Table 1).

8. Sweden currently is only on the wrong side of two thresholds, short-term debt as percent of total debt, around 20 percent; and the fertility rate, 1.9 children per woman. Given the low overall level of public debt and low financing needs, the share of short-term debt in Sweden, around 20 percent of total debt in line with group averages, does not represent a fiscal risk. On the other hand, the fertility rate in Sweden, although below the stress threshold is among the highest in Europe. Furthermore, both thresholds have relatively low signaling power of fiscal distress. On the other hand, it ranks very well in all other dimensions.

\section{B. The Structural Fiscal Balance}

9. Sweden's underlying fiscal strength is also underscored by its strong structural fiscal balance. However, the balance is not straightforward to measure notably regarding the methodology used to estimate the cyclical component of fiscal policy as well as the measure of potential activity.

10. During the recent economic crisis, labor market performance in Sweden was stronger than anticipated. This resulted in an employment gap that was smaller and less volatile than the output gap. Thus, by only using the output gap to make cyclical adjustments, the

\footnotetext{
${ }^{5}$ Sweden, Staff Report for the 1994 Article IV Consultation.
} 
underlying structural fiscal position is over estimated. Similarly, failing to account for temporary stimulus measures taken during the recent crisis, the structural fiscal position would be under estimated. Stimulus measures amounted to 0.1 and 0.6 percent of GDP in 2009 and 2010 respectively.

11. The various estimates of the cyclically adjusted and structural balances using the two gaps are presented in text table 1. Given the appropriate base (employment or output gap) the approach followed here to adjust for the cycle follows the OECD in distinguishing four different types of revenues - corporate and personal income tax, social security contributions and indirect taxes - and household transfers on the spending side. These adjustments are done using the elasticities estimated by the OECD (2005).

12. The range of estimates of the underlying fiscal position obtained from the different methodologies widens in 2009 (with a range from 1.8 to 3.1 percent of GDP) as a result of the divergence between the employment and output gaps. As expected, the failure to account for a better-than-expected performance in the labor market overestimates the underlying fiscal stance whereas the opposite is true if crisis-related stimulus measures are considered permanent rather than transitory.

Text Table 1. Sweden: Estimates of the Underlying Structural Fiscal Position 2004-2010 (in percent of GDP)

\begin{tabular}{|c|c|c|c|c|}
\hline & 2007 & 2008 & 2009 & 2010 \\
\hline CAB - output gap & 1.1 & 1.7 & 2.3 & 1.3 \\
\hline CAB - output gap + employment gap & 1.8 & 1.1 & 1.1 & 0.8 \\
\hline SB - output gap (ignoring stimulus measures) & 0.4 & 1.5 & 2.3 & 1.4 \\
\hline SB - output gap + employment gap (ignoring stimulus measures) & 1.0 & 0.9 & 1.1 & 0.9 \\
\hline SB - output gap (subtracting stimulus measures) & 0.4 & 1.5 & 2.4 & 1.9 \\
\hline SB - output gap + employment gap (subtracting stimulus measures) & 1.0 & 0.9 & 1.3 & 1.4 \\
\hline \multicolumn{5}{|l|}{ Memorandum item } \\
\hline Output gap (in percent) & 5.4 & 1.5 & -5.9 & -3.1 \\
\hline Employment gap (in percent) & 3.6 & 3.0 & -3.4 & -2.0 \\
\hline
\end{tabular}

Source: IMF staff estimates.

13. Thus, the staff preferred measure of the fiscal stance - the last in the list is the text table 1-uses the employment gap to account for the cyclical impact of personal income tax, social security contributions, consumption related taxes and transfers. All other fiscal variables in the staff preferred measure are adjusted using the output gap. All cyclical adjustments are made on a disaggregated basis.

14. The structural balance in Sweden has been at or exceeded the target of 1 percent of GDP over the cycle, even during the crisis. Therefore, while the recent economic crisis deteriorated the overall fiscal position more than 3 percentage points of GDP in 2009, mostly through automatic stabilizers, it has not had an impact on the underlying structural fiscal position, which has remained strong. 
Text Table 2. Sweden: Structural Fiscal Balances 2004-2010 (in percent of GDP)

\begin{tabular}{lrrrrrrr}
\hline & 2004 & 2005 & 2006 & 2007 & 2008 & 2009 & 2010 \\
\cline { 2 - 7 } & 1.1 & 2.3 & 1.9 & 1.0 & 0.9 & 1.3 & 1.4 \\
Staff & 0.4 & 1.6 & 0.8 & 1.2 & 1.7 & 3.0 & 1.8 \\
SB Spring Bill 2011 & 0.7 & 1.7 & 1.6 & 1.7 & 1.6 & 0.2 & 0.6 \\
SB ECB methodology 1/ & & & & & & & \\
Memorandum item & 3.7 & 4.2 & 5.6 & 5.4 & 1.5 & -5.9 & -3.1 \\
$\quad$ Output gap (in percent) & -2.2 & -2.6 & -0.7 & 3.6 & 3.0 & -3.4 & -2.0 \\
$\quad$ Employment gap (in percent) & &
\end{tabular}

1/ Estimated by the Ministry of Finance using the ECB methodology

\section{Shocks Affecting The Baseline}

15. Three kinds of shocks are considered: macroeconomic assumptions, contingent liabilities of the government, and the possibility that policies deviate from those underlying the baseline.

16. Macroeconomic assumptions. While the external environment has improved recently, Sweden's exports depend critically on global demand for consumer durables, capital goods and inventories. In this connection, given the impact of the global and Euro area crisis on the prospects of its key U.S. and European export markets, Sweden's growth outlook is increasingly dependent on its ability to penetrate further export rising emerging markets. Thus, even though fiscal risk factors have been improving, significant macroeconomic risks remain. In particular, on the external side, higher oil prices could result in lower global growth, and, more importantly, continued strains in euro area periphery's sovereigns and banking systems, including potential spillovers to the core, could translate into significantly lower growth in Europe and the rest of the world.

17. Thus, while the broader global outlook is slightly improved since the fall 2010 WEO, the central projection for world growth in 2011-12 is roughly unchanged (the 90 percent confidence interval around these global projections has narrowed, see table 3). Lower growth would result in a deterioration of the overall fiscal position.

18. However, the long-term fiscal impact of a negative growth shock will ultimately depend on the nature of the shock. If the shock is transitory, automatic stabilizers will activate, the fiscal position deteriorate transitorily, and public debt increase somewhat but the underlying structural fiscal position would not deteriorate. On the other hand, if the shock has a permanent component (which is likely if strains in euro area periphery are fully realized), then the underlying fiscal position will deteriorate and the projected solid fiscal position over the medium-term will be reduced. In these circumstances, any structural fiscal reform (particularly on the revenue side) should be postponed until the new structural fiscal position is determined with a reasonable degree of certainty. 
Text Table 3. Sweden: World Economic Outlook (WEO)

\begin{tabular}{|c|c|c|c|c|c|c|}
\hline & \multirow[t]{2}{*}{2009} & \multirow[t]{2}{*}{2010} & \multicolumn{2}{|c|}{2011} & \multicolumn{2}{|c|}{2012} \\
\hline & & & \multicolumn{4}{|c|}{ Projections } \\
\hline \multicolumn{7}{|l|}{ GDP growth } \\
\hline World & -0.5 & 5.0 & & 4 & & .5 \\
\hline European Union & -4.1 & 1.8 & & 8 & & .1 \\
\hline Germany & -4.7 & 3.5 & & 5 & & .1 \\
\hline Sweden & -5.3 & 5.5 & & 8 & & .5 \\
\hline \multicolumn{7}{|c|}{90 percent confidence interval } \\
\hline & & & Lower bound & Upper bound & Lower bound & Upper bound \\
\hline \multicolumn{7}{|l|}{ GDP growth } \\
\hline World & $\ldots$ & $\ldots$ & 2.4 & 6.1 & 1.9 & 7.2 \\
\hline Sweden & $\ldots$ & $\ldots$ & 2.1 & 5.6 & 1.8 & 5.2 \\
\hline
\end{tabular}

Sources: WEO projections (Apr-2011) and staff estimates.

Challenges to the strength of the Sovereign can also come from various other parts of the fiscal system — guarantees, local governments, and PPPs. These are considered next.

19. Contingent liabilities. The National Debt Office is responsible to produce an annual report analyzing the risk for the State from its portfolio of formal and explicit loans and guarantees. The analysis covers medium- and long-term concerns about the potential losses for the state and short-term liquidity risks, that is, the size of the payments that may be necessary in very negative scenarios.

20. A more comprehensive analysis of fiscal risks would include contingent liabilities resulting also from the financial system, public-private partnerships and local governments.

21. The importance of local governments in the provision of basic services including social services, education, and health, means that they can be a source of fiscal risks. As of 2006, total borrowing by local governments amounted to SEK 350 billion or 10 percent of GDP with almost two thirds corresponding to companies owned by local governments. Although local governments decide independently and without scrutiny by the State on their borrowing level and structure, the majority has established limits on foreign currency denominated debt. However, borrowing limits are indirectly established in that debt servicing costs are included in the balanced budget requirement for local governments. The local government funding agency, Kommuninvest i Sverige AB comprising 83 percent of municipalities and with SEK 123.6 billion of outstanding credit in 2009, has top credit ratings reflecting the creditworthiness of the Swedish local government sector. ${ }^{6}$ Rating agencies highlight the excellent quality of its assets and loan exposures.

\footnotetext{
${ }^{6}$ See Standard \& Poor's and Moody's 2010 credit analysis on Kommuninvest i Sverige AB.
} 
22. Although there is significant local self-government, including unrestricted taxation rights at the municipal level, and no explicit guarantee exists, the Swedish state has the ultimate responsibility for the sector overall. In this connection and to reduce the fiscal risks, strong financial requirements are placed on local governments. These include the requirement to, at least, run balanced budgets, and practice sound economic management. Local government's annual reports are required to produce an assessment on how these objectives are met. Finally, the government follows closely economic developments in local governments which are discussed in the Spring Policy Bill and Budget Bill.

23. The more frequent use of some form of public-private partnership (PPP) to implement infrastructure projects represents also a source of potentially significant contingent, explicit or implicit, liabilities. Although interest in different forms of PPPs is growing in Sweden, particularly for railways and roads, so far implementation has been limited, resulting in relatively small contingent liabilities at the moment. Until recently the only PPP project in Sweden consisted of the Arlandabanan railway connecting downtown Stockholm and Arlanda airport in the late 1990s with a cost of around SEK 4.5 billion. In this case, the infrastructure was built and is operated by a private partner which gets reimbursed through ticket proceeds. More recently, at the end of 2010, the new Karolinska Teaching hospital project in Stockholm was approved. It is the largest hospital project built with PPP funding amounting to more than SEK 13 billion.

24. In the 2007 Budget Bill the government established a commission to study the legal, financial, and technical prerequisites for PPPs in the road and rail sectors. The commission provided recommendations on a Swedish specific PPP model and the appropriate legal framework. It also produced a list of suitable investment projects that could be implemented over the next few years. Thus, the importance of PPP projects appears to be increasing in Sweden and thus their associated contingent liabilities. To manage and reduce the associated risks it will be important to (i) integrate PPP projects with the government's investment strategy and it's medium-term fiscal framework; (ii) ensure a robust legal framework; (iii) establish a clear allocation of responsibilities within the government to deal with PPPs including oversight, and risk assessment; and (iv) ensure that the Ministry of Finance is empowered to stop or suspend PPP projects under certain conditions, and has the right of final approval before contract signature. The fiscal impact of PPP projects, including contingent liabilities should be transparently discussed in budget documents and integrated in debt sustainability analysis.

25. Fiscal strength can also be undermined by change in fiscal policy. In Sweden, this risk has been contained by cross party support for the fiscal framework. The fiscal framework grew out of experience from the economic and financial crisis in the 1990s and has three key elements: (i) an unlegislated surplus target established at 1 percent of GDP over the business cycle; (ii) a rolling central government expenditure ceiling established for three years ahead, with a new "third year ceiling added each year, and (iii) a balanced budget requirement for local governments. In implementing this, the Riksdag sets first the total 
expenditure allocations. Appropriations within that ceiling are determined separately and later. The 2011 budget added a year to the horizon for the expenditure ceiling, extending it from three to four years ahead.

26. The fiscal framework has proven effective in ensuring predictable and sustainable government finances and a strong net wealth and fiscal positions. Furthermore, the credibility of the framework has been significantly enhanced during the recent crisis when, without deviating from it, the government was able to provide adequately counter-cyclical fiscal policies. A key element of the fiscal framework is the FPC. The Council has proven to be an effective watchdog of fiscal performance providing more credibility to fiscal policy formulation and implementation. A narrower mandate focusing on the short-term fiscal stance as well as long-term sustainability would enhance its effectiveness. Thus, the strong fiscal framework currently in place reduces significantly the risk of fiscal policy shocks.

27. The current fiscal stance, consistent with that presented in the 2011 Spring Bill, significantly over-performs relative to the fiscal framework requirements, particularly regarding the 1 percent of GDP surplus target. This reflects cyclical improvements from the strong recovery as well as the impact of recent reforms to reduce welfare expenditures and combined with moderate long-term age related spending results in positive long-term fiscal sustainability and net worth projections (text table 4 and Tables $5 \& 6$ ). Given the strongerthan-expected fiscal position during the cyclical downturn in 2009-10, public debt to GDP ratio increased in 2009 by 4 percentage points of GDP to 43 percent of GDP and will gradually fall to around 20 percent of GDP in 2015.

28. Under several alternative scenarios (Figure 2), including a permanent $1 / 2$ standard-deviation shock to growth, interest rate and primary balance independently and a $1 / 4$ standard deviation shock to the three combined, a onetime 30 percent depreciation of the REER, and a one-time 10 percent of GDP shock to contingent liabilities, public debt trajectory remains negative and the increase in the level of debt is moderate in all cases (under the worst case scenario, gross debt would reach 35 percent of GDP in 2015).

\begin{tabular}{|c|c|c|c|c|c|c|c|c|}
\hline & & Baselir & & & & Alternat & e $2 /$ & \\
\hline & 2008 & 2009 & 2010 & 2011 & 2008 & 2009 & 2010 & 2011 \\
\hline Assets & 104 & 106 & 105 & 104 & 104 & 106 & 105 & 104 \\
\hline Financial assets & 63 & 65 & 64 & 62 & 63 & 65 & 64 & 62 \\
\hline Cash \& ST securities & 5 & 5 & 5 & 4 & 5 & 5 & 5 & \\
\hline Equity and mutual funds & 28 & 28 & 28 & 28 & 28 & 28 & 28 & 28 \\
\hline Other & 31 & 32 & 31 & 30 & 31 & 32 & 31 & 30 \\
\hline Capital stock net of depreciation & 41 & 41 & 41 & 41 & 41 & 41 & 41 & 4 \\
\hline Liabilities & 50 & 54 & 51 & 48 & 50 & 54 & 51 & 4 \\
\hline Financ & 50 & 54 & 51 & $4 \varepsilon$ & 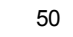 & 4 & 51 & \\
\hline Gross debt & 39 & 43 & 40 & 37 & 39 & 43 & 40 & 3 \\
\hline Other & 11 & 11 & 11 & 11 & 11 & 11 & 11 & \\
\hline Current net worth & 55 & 53 & 54 & 55 & 55 & 53 & 54 & 5 \\
\hline NPV of future fiscal policies (50 years) $3 /$ & 193 & 214 & 208 & 202 & 10 & 16 & 12 & \\
\hline Intertemporal net worth & 247 & 266 & 262 & 258 & 65 & 68 & 66 & 6 \\
\hline Intertemporal financial net worth $4 /$ & 206 & 225 & 221 & 217 & 24 & 27 & 25 & 2 \\
\hline \multicolumn{9}{|c|}{$\begin{array}{l}\text { Source: Swedisch authorities; and Fund staff calculations. } \\
1 / \text { Refers to the baseline medium-term fiscal in the } 2011 \text { Spring Bill (without tax reductions) with a fiscal } \\
\text { position stronger than that required under the fiscal rule. } \\
2 / \text { The alternative scenario assumes fiscal balances over the medium- and long-term consistent with } \\
\text { the } 1 \text { percent of GDP surplus rule. } \\
3 \text { / Stream of discounted projected future primary fiscal balances under current policies and with the } \\
\text { indicated aging costs. Discount rate is the average cost of government funding. } \\
4 / \text { Considers only financial assets and liabilities (i.e. excludes capital stock). This measure is a liquidity } \\
\text { indicator whereas the comprehensive net worth is a solvency indicator. }\end{array}$} \\
\hline
\end{tabular}


29. The likelihood of a fiscal crisis not only depends on variables that directly affect the public sector balance sheet but also on the overall condition of the economy, including the availability of overall savings. There is some evidence to support that countries facing 'twin' deficits are more likely to suffer speculative attacks, which could also lead to a liquidity crisis for the government.

30. These risks appear moderate in Sweden; except for small fiscal deficits in 2009 and 2010, the current account and fiscal positions are projected to be in surplus over the medium-term.
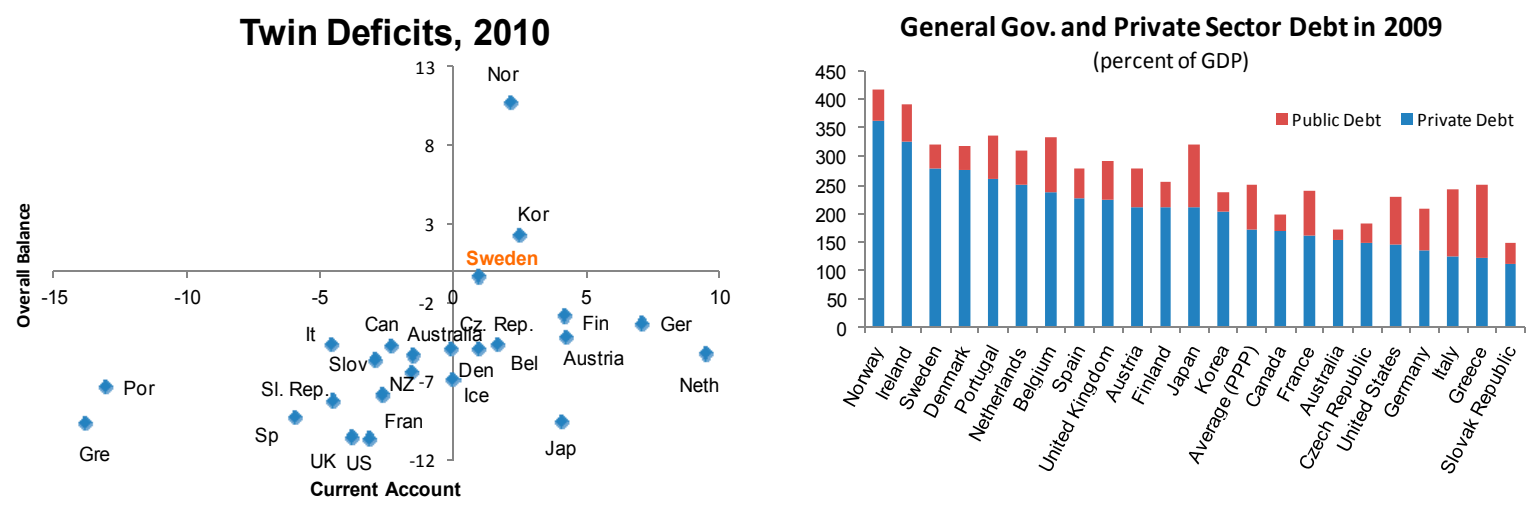

31. Last, challenges to the strength of the sovereign can come from implicit contingent liabilities in particular from the financial sector. In Sweden this risk is significant. The risk is magnified by the large level of private debt. At 280 percent of GDP it is one of the highest in the world (third highest in the group of countries shown in text figure) and comparable to countries like Ireland, Portugal, the United Kingdom and Spain.

32. The financial system in Sweden is large, above 500 percent of GDP, concentrated four major banks hold 65 percent of the market share and has extensive cross-border operations and non-banking activities with substantial reliance on wholesale funding markets. Thus, it represents a significant contingent fiscal risk.

33. However, its resilience has strengthened considerably after the crisis (major banks have raised capital to well above regulatory requirements, their exposure to peripheral European economies is small, and their loan losses in the Baltics have fallen).

34. Three risks remain; Euro area tail risks, housing market, and the size of the financial system. The assessment of the recent FSAP is that, based on two of these three risks, the financial system in Sweden is generally sound. This credit assessment is not predicated on Euro area tail risks but on adverse macroeconomic scenario (prolonged low growth and a domestic housing market crash).

35. Estimates of the net direct support to the financial system provided by the countries most affected by the recent crisis are presented in text chart 1 together with similar estimates 
for the Nordic countries during the crisis in the $90 \mathrm{~s} .{ }^{7}$ The cost of direct support varies enormously across countries but takes no account of the short- or long-term output and employment costs incurred. It can be very significant, almost 30 percent of GDP in the case of Ireland.

36. Given the large size of the financial system in Sweden, it is not enough to keep fiscal variables at 'prudent' levels so that when a shock hits, public debt can act as a shock absorber. Therefore, reducing the fiscal risks associated to the financial system through front-running Basel III's capital and liquidity requirements (making them even stronger), further

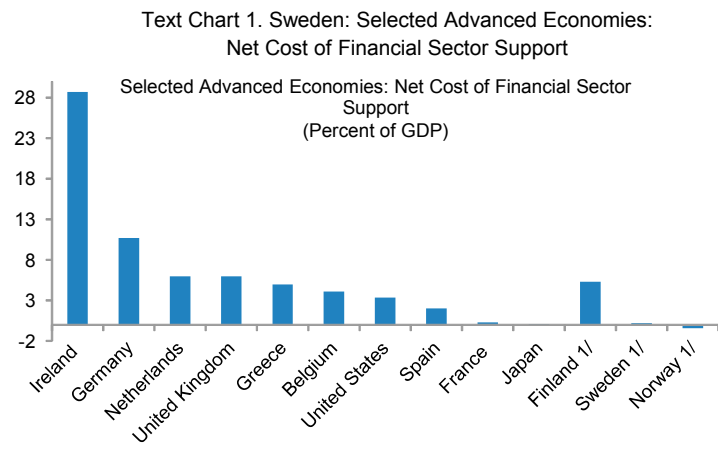

Source: Fincal Monitor. developing the macro-prudential framework and adequately funding prudential supervision, is critical to preserve Sweden's strong fiscal position and long-run fiscal sustainability.

\section{Capacity to React to Realized Fiscal Risks ${ }^{8}$}

37. The last element in assessing the strength of the sovereign concerns the ability of the political and social system to adjust policies as needed if large fiscal shocks materialize. Ostry et. al., (2010) look at this question by defining a 'debt limit' that is consistent with the country's historical track record of adjustment. They determined a threshold above which fiscal efforts to maintain fiscal sustainability have to exceed the country's fiscal response to rising debt observed in the past. Table 3 presents results from Ostry et. al., (2010) for two interest rate assumptions, one where the market rate reflects the perceived probability of default and the other taking into account the rising risk of default as debt approaches its limit. Long-term public debt levels to which the economy converges if debt never exceeds the debt limit are also reported.

38. Although subject to uncertainty, the estimated fiscal space, abstracting from shortterm liquidity risks, is large in general, 60 percent of GDP on average ( 80 percent for European countries). In the case of Sweden, the space is almost three times as large (more than twice relative to European countries) at 170 percent of GDP. This is largely the result of a low initial level of public debt, projected by end-2015 to be 38 percent of GDP. Only Australia, Korea and New Zealand are projected to have lower debt levels. On average, their

\footnotetext{
${ }^{7}$ The net fiscal cost is defined as total outlays net of recovery by end-June 2010. As further recovery will be possible by divesting assets that the government still holds, the net fiscal cost is an upper bound of the expected net loss of financial sector support. For more details see IMF (2010).

${ }^{8}$ This section builds on IMF Staff Position Note "Fiscal Space" by Ostry et. al., 2010.
} 
sample of countries is projected to have a debt level in excess of 110 percent of GDP (93 percent of GDP in the case of European economies). This implies that Sweden has a large capacity to deal with extraordinary shocks. However, the feasibility to use the whole buffer critically depends on short-term liquidity considerations not triggering a rollover crisis. Indeed, the 2008-10 financial crisis highlights the need to create large fiscal space in order for advanced economies to absorb potential extraordinary shocks.

\section{E. Conclusion}

39. Sweden fiscal risks appear moderate and the fiscal buffers to deal with these risks adequate. Basic fiscal variables, long-term fiscal indicators, sovereign asset and liability composition and financing requirements indicate that the probability of fiscal distress is small. In contrast, in advanced countries fiscal risks remain elevated and well above precrisis levels. A robust and credible fiscal framework provides predictability and transparency to fiscal policies reducing volatility and risks. The key task is to ensure that potential risks from the financial sector are contained.

40. These financial sector risks could be aggravated by euro area tail risks and high domestic private debt. If peripheral European economies risks materialize, they could have a significant negative impact in Sweden that, unlike the recent economic downturn, will be more persistent. The associated fiscal risks and contingent liabilities should be reduced by continued progress to build fiscal buffers, and by aggressive implementation of steps to strengthen macro prudential and regulatory institutions and policies. 


\section{References}

Baldacci, Emanuele, James McHugh and Iva Petrova, 2011, "Measuring Fiscal Vulnerabilityand Fiscal Stress: A Proposed Set of Indicators," IMF Working Paper 11/94 (Washington: International Monetary Fund).

Baldacci, Emanuele, Iva Petrova, Nazim Belhocine, Gabriela Dobrescu, and Samah Mazraani, 2011, “Assessing Fiscal Stress,” IMF Working Paper 11/100 (Washington: International Monetary Fund).

Cottarelli, Carlo, 2011, "The Risk Octagon: A Comprehensive Framework for Assessing Sovereign Risks" presented in University of Rome "La Sapienza," January.

Girouard, Nathalie and Christophe André, 2005, "Measuring Cyclically-adjusted Budget Balances for OECD Countries," OECD Economic Department Working Paper No. 434 (Paris: Organization for Economic Co-operation and Development).

IMF, 2010, Fiscal Monitor, November (Washington: International Monetary Fund).

IMF, 2011, Fiscal Monitor, April (Washington: International Monetary Fund).

Ostry, Jonathan D., Atish R. Ghosh, Jun I. Kim, and Mahvash S. Qureshi, "Fiscal Space," IMF Staff Position Note 10/11 (Washington: International Monetary Fund).

Swedish Fiscal Policy Council, 2011, Swedish Fiscal Policy 2011, May. 
Figure 1. Indicators of Fiscal Vulnerability and Fiscal Stress
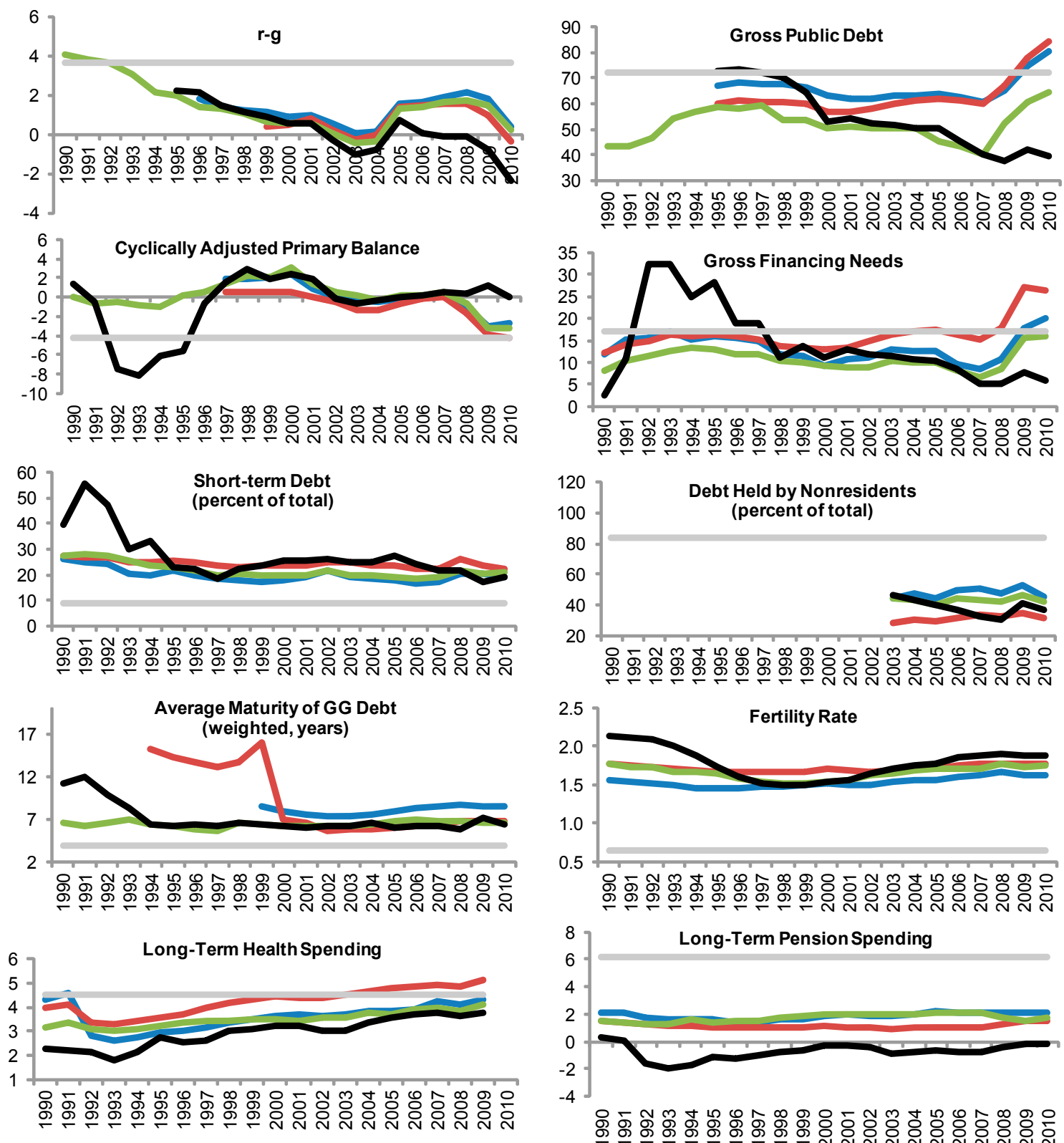

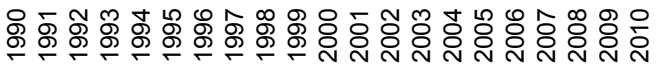

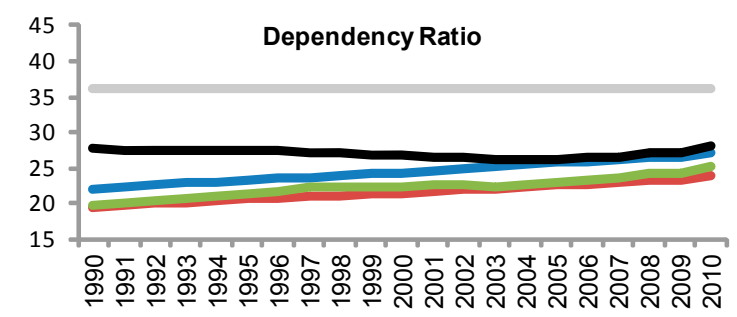

$\longrightarrow$ Average (PPP, Europe) $\quad$ Average (PPP) $\quad$ Median $\longrightarrow$ Sweden Threshold

Source: World Economic Outlook; Bank of International Settlements; Dealogic, and IMF. 
Table 1. Advanced Economies: Fiscal Indicators in 2010

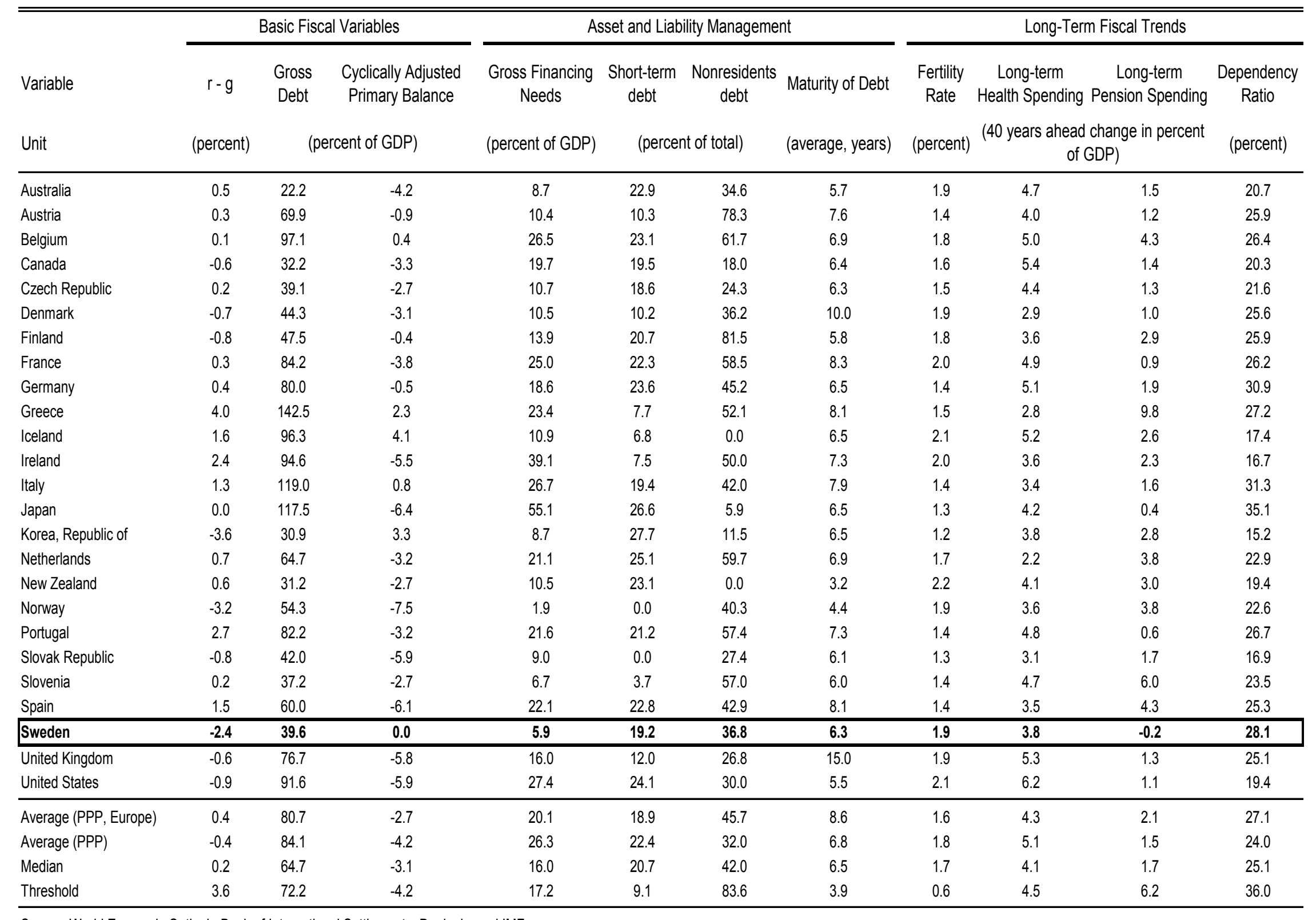

Source: World Economic Outlook; Bank of International Settlements; Dealogic; and IMF. 
Table 2. Country: Public Sector Debt Sustainability Framework, 2005-2015

(In percent of GDP, unless otherwise indicated)

\begin{tabular}{|c|c|c|c|c|c|c|c|c|c|c|c|c|}
\hline & \multicolumn{5}{|c|}{ Actual } & \multicolumn{6}{|c|}{ Projections } & \multirow{3}{*}{$\begin{array}{c}\text { Debt-stabilizing } \\
\text { primary } \\
\text { balance } 9 /\end{array}$} \\
\hline & 2005 & 2006 & 2007 & 2008 & 2009 & 2010 & 2011 & 2012 & 2013 & 2014 & 2015 & \\
\hline & & & & & & & & & & & & \\
\hline $\begin{array}{l}\text { Baseline: Public sector debt } 1 / \\
\text { o/w foreign-currency denominated }\end{array}$ & $\begin{array}{l}50.4 \\
11.0\end{array}$ & $\begin{array}{r}45.3 \\
9.0\end{array}$ & $\begin{array}{r}40.2 \\
7.4\end{array}$ & $\begin{array}{r}38.8 \\
7.0\end{array}$ & $\begin{array}{l}42.8 \\
10.6\end{array}$ & $\begin{array}{r}39.8 \\
8.2\end{array}$ & $\begin{array}{r}36.1 \\
7.4\end{array}$ & $\begin{array}{r}32.7 \\
6.7\end{array}$ & $\begin{array}{r}29.2 \\
6.1\end{array}$ & $\begin{array}{r}25.8 \\
5.5\end{array}$ & $\begin{array}{r}22.5 \\
4.7\end{array}$ & -0.2 \\
\hline Change in public sector debt & 0.1 & -5.1 & -5.0 & -1.4 & 4.0 & -3.0 & -3.7 & -3.4 & -3.4 & -3.4 & -3.3 & \\
\hline Identified debt-creating flows $(4+7+12)$ & -1.8 & -6.7 & -6.7 & -1.4 & 3.6 & -2.4 & -3.7 & -3.4 & -3.4 & -3.4 & -3.3 & \\
\hline Primary deficit & -3.8 & -3.9 & -5.3 & -3.9 & -0.2 & -0.7 & -2.1 & -2.4 & -2.8 & -3.1 & -3.0 & \\
\hline Revenue and grants & 53.8 & 53.0 & 52.5 & 51.9 & 52.1 & 50.7 & 49.3 & 48.6 & 48.6 & 48.4 & 48.4 & \\
\hline Primary (noninterest) expenditure & 50.0 & 49.0 & 47.2 & 48.0 & 51.9 & 50.1 & 47.2 & 46.2 & 45.8 & 45.4 & 45.4 & \\
\hline Automatic debt dynamics $2 /$ & 2.0 & -2.8 & -1.4 & 2.5 & 3.8 & -1.7 & -1.6 & -1.0 & -0.6 & -0.4 & -0.3 & \\
\hline Contribution from interest rate/growth differential $3 /$ & -0.1 & -1.3 & -0.9 & 0.7 & 2.6 & -1.7 & -1.6 & -1.0 & -0.6 & -0.4 & -0.3 & \\
\hline Of which contribution from real interest rate & 1.4 & 0.8 & 0.5 & 0.4 & 0.5 & 0.5 & 0.0 & 0.3 & 0.4 & 0.5 & 0.4 & \\
\hline Of which contribution from real GDP growth & -1.5 & -2.0 & -1.4 & 0.2 & 2.1 & -2.2 & -1.6 & -1.3 & -1.1 & -0.8 & -0.6 & \\
\hline Contribution from exchange rate depreciation $4 /$ & 2.1 & -1.5 & -0.5 & 1.8 & 1.2 & & $\ldots$ & $\ldots$ & $\ldots$ & $\ldots$ & $\ldots$ & \\
\hline Other identified debt-creating flows & 0.0 & 0.0 & 0.0 & 0.0 & 0.0 & 0.0 & 0.0 & 0.0 & 0.0 & 0.0 & 0.0 & \\
\hline Privatization receipts (negative) & 0.0 & 0.0 & 0.0 & 0.0 & 0.0 & 0.0 & 0.0 & 0.0 & 0.0 & 0.0 & 0.0 & \\
\hline Recognition of implicit or contingent liabilities & 0.0 & 0.0 & 0.0 & 0.0 & 0.0 & 0.0 & 0.0 & 0.0 & 0.0 & 0.0 & 0.0 & \\
\hline Other (specify, e.g. bank recapitalization) & 0.0 & 0.0 & 0.0 & 0.0 & 0.0 & 0.0 & 0.0 & 0.0 & 0.0 & 0.0 & 0.0 & \\
\hline Residual, including asset changes (2-3) 5/ & 1.8 & 1.6 & 1.7 & 0.0 & 0.3 & -0.6 & 0.0 & 0.0 & 0.0 & 0.0 & 0.0 & \\
\hline Public sector debt-to-revenue ratio $1 /$ & 93.7 & 85.4 & 76.6 & 74.8 & 82.0 & 78.4 & 73.2 & 67.2 & 60.2 & 53.3 & 46.5 & \\
\hline Gross financing need $6 /$ & 17.2 & 16.9 & 12.9 & 10.8 & 13.3 & 12.7 & 10.5 & 9.2 & 7.6 & 6.2 & 5.1 & \\
\hline in billions of U.S. dollars & 63.7 & 67.6 & 59.8 & 52.5 & 53.8 & 58.4 & 60.1 & 57.7 & 51.2 & 43.9 & 38.0 & \\
\hline Scenario with key variables at their historical averages $7 /$ & & & & & & 39.8 & 36.6 & 33.5 & 30.3 & 27.1 & 24.0 & 0.1 \\
\hline Scenario with no policy change (constant primary balance) in 2010-2015 & & & & & & 39.8 & 37.5 & 35.8 & 34.4 & 33.3 & 32.3 & -0.4 \\
\hline \multicolumn{13}{|l|}{ Key Macroeconomic and Fiscal Assumptions Underlying Baseline } \\
\hline Real GDP growth (in percent) & 3.2 & 4.3 & 3.3 & -0.6 & -5.3 & 5.5 & 4.4 & 3.8 & 3.5 & 3.0 & 2.5 & \\
\hline Average nominal interest rate on public debt (in percent) $8 /$ & 3.9 & 3.6 & 4.1 & 4.2 & 2.9 & 2.5 & 3.4 & 3.3 & 3.5 & 3.7 & 3.5 & \\
\hline Average real interest rate (nominal rate minus change in GDP deflator, in percent) & 3.0 & 1.7 & 1.4 & 1.1 & 1.1 & 1.3 & 0.2 & 0.9 & 1.5 & 1.7 & 1.5 & \\
\hline Nominal appreciation (increase in US dollar value of local currency, in percent) & -15.8 & 16.3 & 5.7 & -19.3 & -13.9 & $\ldots$ & $\ldots$ & $\ldots$ & $\ldots$ & $\ldots$ & $\ldots$ & \\
\hline Inflation rate (GDP deflator, in percent) & 0.9 & 1.9 & 2.8 & 3.1 & 1.8 & 1.3 & 3.1 & 2.5 & 2.0 & 2.0 & 2.0 & \\
\hline Growth of real primary spending (deflated by GDP deflator, in percent) & 2.4 & 2.3 & -0.5 & 1.0 & 2.4 & 1.8 & -1.6 & 1.6 & 2.6 & 2.1 & 2.5 & \\
\hline Primary deficit & -3.8 & -3.9 & -5.3 & -3.9 & -0.2 & -0.7 & -2.1 & -2.4 & -2.8 & -3.1 & -3.0 & \\
\hline
\end{tabular}

1/ It covers gross debt of the general government

2/ Derived as $[(r-\pi(1+g)-g+\alpha \varepsilon(1+r)] /(1+g+\pi+g \pi))$ times previous period debt ratio, with $r=$ interest rate; $\pi=$ growth rate of GDP deflator; $g=$ real GDP growth rate; $\alpha=$ share of foreign-currency

denominated debt; and $\varepsilon=$ nominal exchange rate depreciation (measured by increase in local currency value of U.S. dollar).

$3 /$ The real interest rate contribution is derived from the denominator in footnote $2 /$ as $r-\pi(1+g)$ and the real growth contribution as $-g$.

$4 /$ The exchange rate contribution is derived from the numerator in footnote $2 /$ as $\alpha s(1+r)$.

$5 /$ For projections, this line includes exchange rate changes.

6/ Defined as public sector deficit, plus amortization of medium and long-term public sector debt, plus short-term debt at end of previous period.

7/ The key variables include real GDP growth; real interest rate; and primary balance in percent of GDP.

8/ Derived as nominal interest expenditure divided by previous period debt stock.

9/ Assumes that key variables (real GDP growth, real interest rate, and other identified debt-creating flows) remain at the level of the last projection year. 
Figure 2. Sweden: Public Debt Sustainability: Bound Tests 1/ (Public debt in percent of GDP)

Baseline and historical scenarios

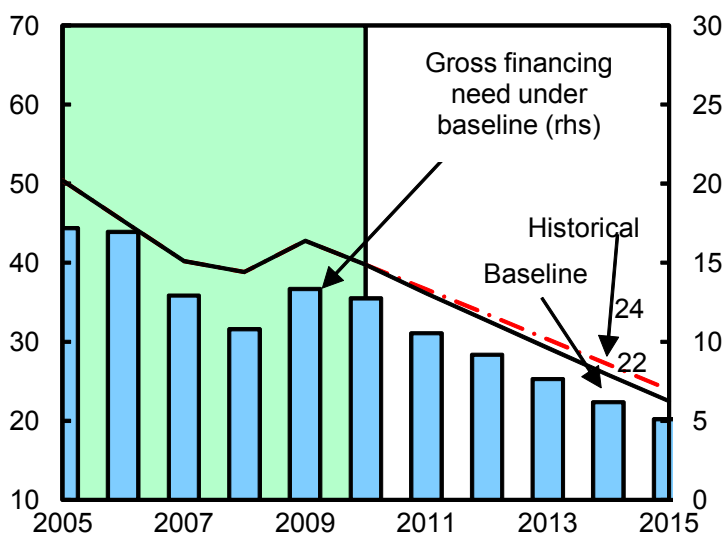

Growth shock

(in percent per year)

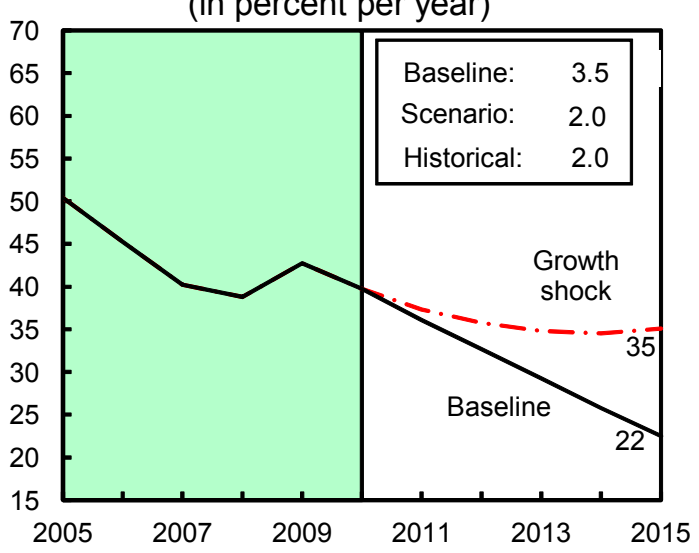

Combined shock 2/

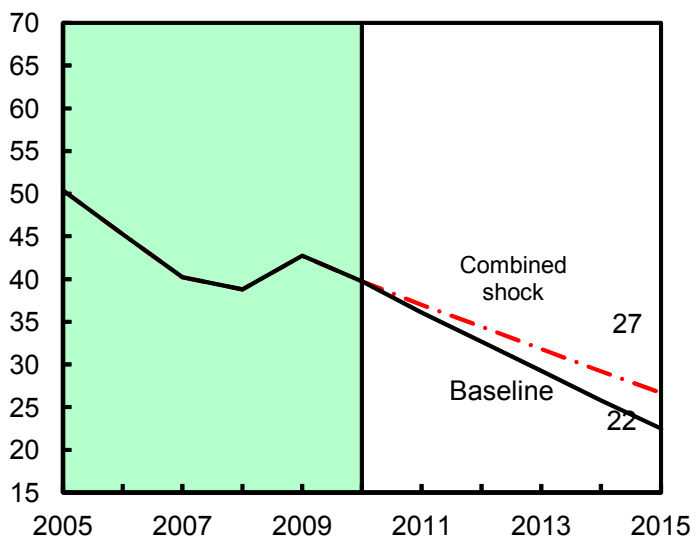

Interest rate shock (in percent)

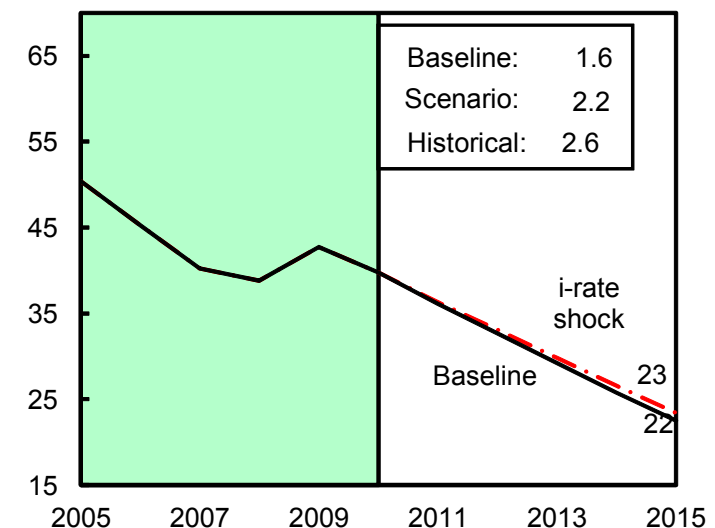

Primary balance shock (in percent of GDP) and no policy change scenario (constant primary balance)

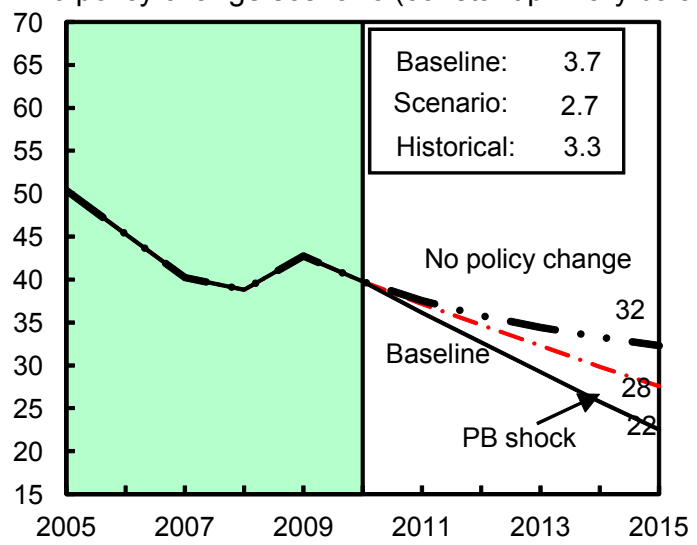

Real depreciation and contingent liabilities shocks $3 /$

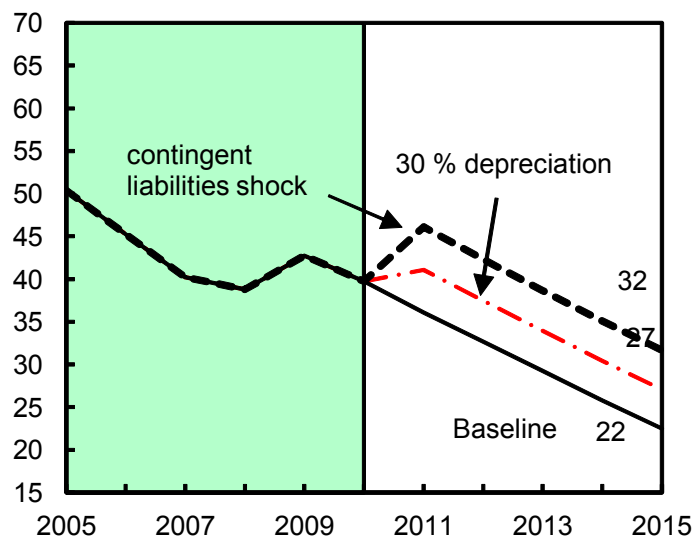

1/ Shaded areas represent actual data. Individual shocks are permanent one-half standard deviation shocks. Figures in the boxes represent average projections for the respective variables in the baseline and scenario being presented. Tenyear historical average for the variable is also shown.

2/ Permanent 1/2 standard deviation shocks applied to real interest rate, growth rate, and primary balance.

$3 /$ One-time real depreciation of 30 percent and 10 percent of GDP shock to contingent liabilities occur in 2010, with real depreciation defined as nominal depreciation (measured by percentage fall in dollar value of local currency) minus domestic inflation (based on GDP deflator). 
Table 3. Fiscal Space in Advanced Economies

\begin{tabular}{|c|c|c|c|c|c|c|c|c|c|}
\hline \multirow[b]{4}{*}{ Australia } & \multirow{4}{*}{$\begin{array}{r}\begin{array}{c}\text { Debt } \\
\text { (end-2015) }\end{array} \\
\\
\\
20.9\end{array}$} & \multicolumn{5}{|c|}{ Market Interest Rate } & \multicolumn{3}{|c|}{ Model-implied Interest Rate } \\
\hline & & \multicolumn{2}{|c|}{$\begin{array}{c}\text { Long-run Average } \\
\text { Debt }\end{array}$} & \multicolumn{2}{|c|}{ Debt Threshold } & \multirow{3}{*}{$\begin{array}{r}\text { Fiscal } \\
\text { Space } \\
172.3\end{array}$} & \multirow{3}{*}{$\begin{array}{l}\text { Long-run } \\
\begin{array}{c}\text { Average } \\
\text { Debt }\end{array} \\
0.0\end{array}$} & \multirow{3}{*}{$\begin{array}{c}\text { Debt } \\
\text { Threshold } \\
202.7\end{array}$} & \multirow{3}{*}{$\begin{array}{r}\text { Fiscal } \\
\text { Space } \\
181.8\end{array}$} \\
\hline & & \multirow{2}{*}{$\begin{array}{r}\text { Historical } \\
0.0\end{array}$} & \multirow{2}{*}{$\begin{array}{r}\text { Projected } \\
0.0\end{array}$} & \multirow{2}{*}{$\begin{array}{r}\text { Historical } \\
203.9\end{array}$} & Projected & & & & \\
\hline & & & & & 193.2 & & & & \\
\hline Austria & 77.3 & 63.9 & 54.3 & 179.7 & 187.3 & 110.0 & 55.1 & 170.7 & 93.4 \\
\hline Belgium & 99.9 & 60.3 & 76.3 & 182.0 & 168.4 & 68.5 & 53.7 & 172.0 & 72.1 \\
\hline Canada & 71.2 & 110.8 & 82.6 & 152.3 & 181.1 & 109.9 & 75.2 & 173.1 & 101.9 \\
\hline Denmark & 49.8 & 0.0 & 0.0 & 175.7 & 208.7 & 158.9 & 0.0 & 195.9 & 146.1 \\
\hline Finland & 76.1 & 0.0 & 0.0 & 200.4 & 184.5 & 108.4 & 0.0 & 167.0 & 90.9 \\
\hline France & 94.8 & 94.8 & 89.8 & 170.9 & 176.1 & 81.3 & 92.7 & 159.7 & 64.9 \\
\hline Germany & 81.5 & 94.5 & 71.0 & 154.1 & 175.8 & 94.3 & 63.6 & 170.0 & 88.5 \\
\hline Greece & 158.6 & 80.5 & & 196.5 & & & & & \\
\hline Iceland & 86.6 & 0.0 & & 213.5 & & & 0.0 & 157.3 & 70.7 \\
\hline Ireland & 94.0 & 0.0 & 90.7 & 245.7 & 149.7 & 55.7 & 42.9 & 157.6 & 63.6 \\
\hline Israel & 69.9 & 79.7 & 82.1 & 184.8 & 182.4 & 112.5 & 65.0 & 183.9 & 114.0 \\
\hline Italy & 124.7 & & & & & & & & \\
\hline Japan & 250.0 & & & & & & & & \\
\hline Korea & 26.2 & 0.0 & 0.0 & 217.2 & 229.2 & 203.0 & 0.0 & 220.3 & 194.1 \\
\hline Netherlands & 77.4 & 50.2 & 50.7 & 190.5 & 190.1 & 112.7 & 58.0 & 168.7 & 91.3 \\
\hline New Zealand & 36.1 & 0.0 & 0.0 & 201.0 & 186.4 & 150.3 & 0.0 & 197.6 & 161.5 \\
\hline Norway & 53.6 & 0.0 & 0.0 & 263.2 & 249.2 & 195.6 & 0.0 & 233.5 & 179.9 \\
\hline Portugal & 98.4 & 77.1 & & 191.6 & & & & & \\
\hline Spain & 94.4 & 0.0 & 94.8 & 218.3 & 153.9 & 59.5 & 70.2 & 168.4 & 74.0 \\
\hline Sweden & 37.6 & 0.0 & 0.0 & 203.5 & 204.9 & 167.3 & 0.0 & 167.8 & 130.2 \\
\hline United Kingdom & 90.6 & 79.6 & 94.9 & 182.0 & 166.5 & 75.9 & 75.5 & 166.0 & 75.4 \\
\hline United States & 109.7 & 78.7 & 101.2 & 183.3 & 160.5 & 50.8 & 77.6 & 173.1 & 63.4 \\
\hline Average (PPP, Europe) & 92.5 & 66.0 & 74.8 & 182.0 & 175.2 & 82.7 & 65.4 & 168.7 & 76.2 \\
\hline Average (PPP) & 112.4 & 68.9 & 82.2 & 183.7 & 171.4 & 59.0 & 66.6 & 174.8 & 62.3 \\
\hline Median & 81.5 & 50.2 & 62.6 & 191.6 & 183.4 & 101.9 & 53.7 & 170.7 & 89.2 \\
\hline Sweden & 37.6 & 0.0 & 0.0 & 203.5 & 204.9 & 167.3 & 0.0 & 167.8 & 130.2 \\
\hline Mean & 86.1 & 41.4 & 49.3 & 195.7 & 186.0 & 99.9 & 38.4 & 179.2 & 93.2 \\
\hline
\end{tabular}

Source: "Fiscal Space"; by Ostry et al.; 2010; IMF Staff Position Note; SPN/10/11. 


\section{Appendix I}

As introduced in the Fiscal Monitor (IMF 2010, 2011) and Cottarelli (2011), the risk framework followed here is based on a comprehensive view of all factors that affect the probability that the move of certain fiscal indicators into dangerous territory, or other shocks, could trigger a negative market response. These indicators can be grouped into (i) basic fiscal variables; (ii) long-term fiscal indicators; and (iii) asset and liability management indicators.

The choice of indicators identified in Baldacci et. al., (2011a) measures fiscal sustainability risks under the medium-term scenario of the World Economic Outlook baseline projections. These indicators measure solvency risks based on current deficit and debt levels, and projected growth-adjusted interest rate on public debt. Indicators of long-term budget pressures associated with demographic aging, such as projected change in health care and pension expenditures, are also included. In addition to the solvency risk outlook, the framework also covers risks to fiscal sustainability stemming from sovereign asset and liability composition and financing requirements.

The choice of indicators is subject to operational constraints and avoids using financial market indicators. These indicators already incorporate an assessment of risk to the baseline (including both rollover risks and risks from potential shocks to the baseline), they also incorporate the perceived probability of government's accessing non-market financing to avoid insolvency and they tend to lag rather than lead the deterioration in fiscal fundamentals.

The indicators are presented against a threshold that, when exceeded, indicates a higher risk of fiscal stress. This is defined as a crisis episode that encompasses public debt default as well as near-default events and severe deterioration in solvency risk outlook. The thresholds are estimated in Baldacci et. al., (2011b) on the basis of a univariate procedure that maximizes the likelihood of predicting a fiscal crisis. Each of the nine variables used has different predicted power defined as one minus the total error and it is a measure of the statistical power of the variable. Table 1 lists all the variables, their respective thresholds and their signaling power in an index form so that the total sum is 100 . 
Threshold and Relative Weight of Fiscal Indicators for Advanced Economies

\begin{tabular}{lrr}
\hline Indicator & Threshold & Signaling weight \\
\hline Basic Fiscal Variables & & \\
r - g (5-year average) & 3.6 & 14.9 \\
Cyclically adjusted primary balance & 72.2 & 7.3 \\
General government gross/net debt & -4.2 & 9.4 \\
Long-Term Fiscal Trends & & \\
Total fertility rate & 0.64 & 2.4 \\
Old age dependency ratio & 36.0 & 4.5 \\
Long-term projections of the change in public pension expenditure & 6.2 & 9.6 \\
Long-term projections of the change in public health expenditure & 4.5 & 9.4 \\
Asset and Liability Management & & \\
Current gross financing need & 17.2 & 24.6 \\
Share of short-term debt as a ratio of total debt & 9.1 & 2.8 \\
Debt held by non-residents as a proportion of total debt & 83.6 & 10.1 \\
Weighted average maturity of general government debt & 3.9 & 5.0 \\
\hline
\end{tabular}

Source: Assessing Fiscal Stress; Baldacci et.al., 2011b

\begin{tabular}{|c|c|c|}
\hline Indicator & Comments & Data Source \\
\hline \multicolumn{3}{|l|}{ Basic Fiscal Variables } \\
\hline $\mathrm{r}$ - g (5-year average) & $\begin{array}{l}\text { Imputed inerest rate on general government debt, } \\
\text { deflated by the GDP deflator, minus real GDP growth } \\
\text { rate; five year forward moving average }\end{array}$ & WEO \\
\hline $\begin{array}{l}\text { Cyclically adjusted primary } \\
\text { balance }\end{array}$ & Expressed as a percent of potential GDP & WEO \\
\hline $\begin{array}{l}\text { General government gross/net } \\
\text { debt }\end{array}$ & $\begin{array}{l}\text { Expressed in percent of GDP. Net debt used for Japan } \\
\text { and Canada, gross debt for all other countries }\end{array}$ & WEO \\
\hline \multicolumn{3}{|l|}{ Long-Term Fiscal Trends } \\
\hline Total fertility rate & The average number of children per woman & UN \\
\hline Old age dependency ratio & $\begin{array}{l}30 \text { years ahead projections of the ratio of the population } \\
\text { over } 65 \text {, divided by the number of adults }\end{array}$ & UN \\
\hline $\begin{array}{l}\text { Long-term projections of the } \\
\text { change in public pension } \\
\text { expenditure } \\
\text { Long-term projections of the } \\
\text { change in public health } \\
\text { expenditure }\end{array}$ & $\begin{array}{l}\text { Expressed as in percent of GDP, the change in } \\
\text { projected expenditures } 40 \text { years ahead relative to the } \\
\text { base year } \\
\text { Expressed as in percent of GDP, the change in } \\
\text { projected expenditures } 40 \text { years ahead relative to the } \\
\text { base year }\end{array}$ & Staff estimates \\
\hline \multicolumn{3}{|l|}{$\begin{array}{l}\text { Asset and Liability } \\
\text { Management }\end{array}$} \\
\hline Current gross financing need & $\begin{array}{l}\text { Projected general government overall balance plus } \\
\text { general government debt with a maturity of one year or } \\
\text { less; expressed in percent of GDP }\end{array}$ & WEO, Bloomberg \\
\hline $\begin{array}{l}\text { Share of short-term debt as a } \\
\text { ratio of total debt }\end{array}$ & $\begin{array}{l}\text { Short-term debt is defined as general government debt } \\
\text { with a maturity of one year or less. Total debt is general } \\
\text { government gross debt }\end{array}$ & WEO, Bloomberg \\
\hline $\begin{array}{l}\text { Debt held by non-residents as a } \\
\text { proportion of total debt }\end{array}$ & $\begin{array}{l}\text { Includes both domestic and foreign currency issued } \\
\text { debt; expressed as a proportion of total debt }\end{array}$ & BIS \\
\hline $\begin{array}{l}\text { Weighted average maturity of } \\
\text { general government debt }\end{array}$ & $\begin{array}{l}\text { Historical data calculated by staff; current data available } \\
\text { from Bloomberg }\end{array}$ & Bloomberg, Dealogic \\
\hline
\end{tabular}

Source: Indicators of Fiscal Vulnerability and Fiscal Stress; Baldacci et al.; 2011a 


\section{ATtaChment III-RESERVE AdeQuaCY ${ }^{1}$}

\section{A. Lessons From the Global Crisis}

1. Pre-crisis, the Swedish authorities, like others in advanced countries, assumed that there was little rationale for holding precautionary foreign exchange reserves, because they would have access to markets even under adverse conditions. However, the crisis experience revealed the need to rethink foreign exchange reserve adequacy.

2. The global financial crisis severely affected the Swedish banking system. Swedish banks, similar to other large European banks, relied substantially on wholesale dollar and euro funding, by issuing commercial paper, covered bonds, and other debt instruments, and used the foreign exchange swap market extensively. After the collapse of Lehman Brothers in September 2008, with increased counterparty risks, funding and currency swap markets were impaired, and Swedish banks faced constraints in funding and hedging.

3. In response, the Riksbank introduced a US dollar lending facility to ease liquidity strains. And to finance this, the authorities boosted foreign exchange reserves in mid-crisis. The Riksbank arranged reciprocal swap facilities with the Federal Reserve, while National Debt Office (NDO) borrowed externally SEK 100 billion (US\$ 15 billion). ${ }^{2}$ At its peak (April 2009), the Riksbank's US dollar lending amounted to $\$ 30$ billion, most of which was financed by the swap. If the swap had not been in place, the total amount of the US dollar lending would have exceeded the stock of foreign exchange reserves at that time (\$28 billion).
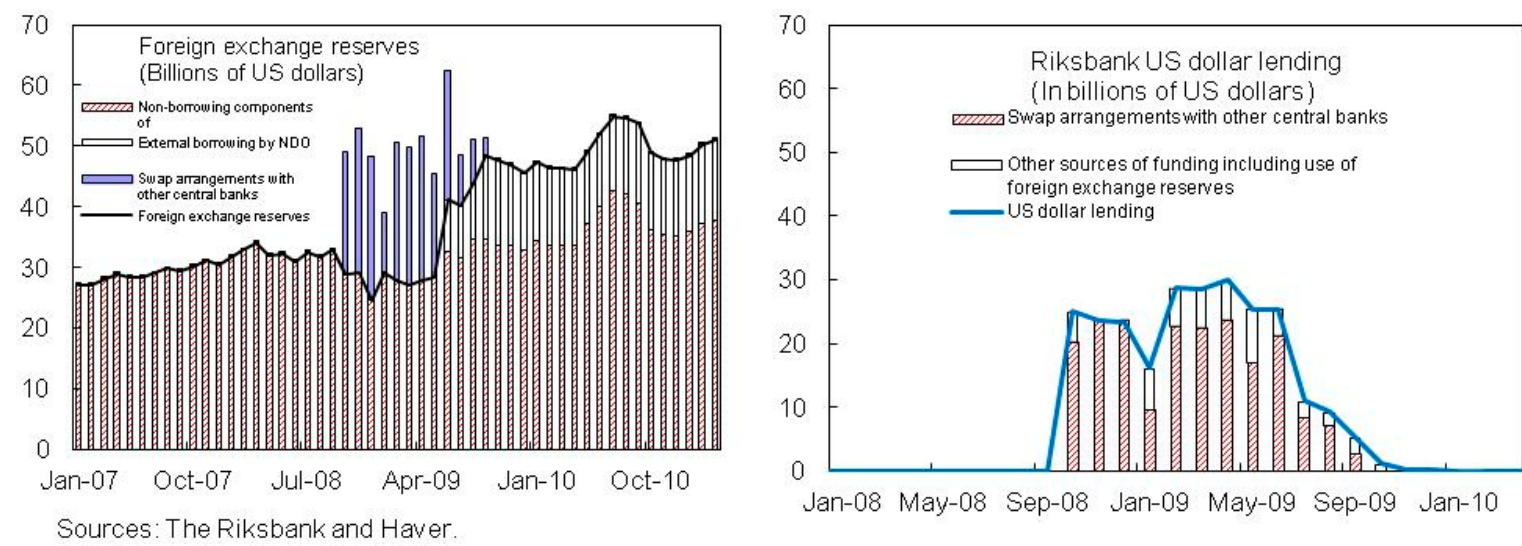

\footnotetext{
${ }^{1}$ Prepared by Kotaro Ishi (EUR).

${ }^{2}$ In Sweden, the statutory responsibility of international reserve management is defined as following. Sveriges Riksbank Act (Riksbank Act) mandates the Riksbank to manage international reserves (Chapter 7, Article 2.), while the Budget Act allows the NDO to borrow externally on behalf of the Riksbank.
} 
4. This response was effective. By the summer of 2009, strains in funding markets started easing, and demand for the Riksbank's dollar lending facility declined. And the Riksbank terminated the US dollar lending facility at end-2009. Nonetheless, the Riksbank maintains a high level of foreign exchange reserves.

5. This crisis experience has reopened the issue of foreign exchange reserve adequacy, because inadequacy of foreign exchange reserve could have called into question the ability of the Riksbank to act as an emergency liquidity provider in support of financial system stability.

\section{B. Traditional Metrics of Reserve Adequacy}

6. There is no consensus on how foreign exchange reserve adequacy be defined. In many cases, the simple rules of thumb are used. These metrics are: GDP; import cover; broad money; and short-term external debt.

7. Sweden fares better than other advanced economies in all these metrics. At end-2010, Sweden's foreign exchange reserves amounted to 10 percent of GDP, 18 percent of broad money, 2 percent of imports of goods and services, and 18 percent of bank short-term debts (Figure 1). All these exceeded the median of advanced economies (Figure 2).

8. However, these traditional approaches offer little insight in assessing reserve adequacy in advanced countries. The GDP metric has little theoretical or empirical grounding. The import cover metric is also not immediately relevant, given that Sweden is a large capital account surplus country. With strong institutions and sound macroeconomic policy framework, the broad money metric also has little traction.

9. Of the traditional metrics, the debt metric appears to be most useful for advanced countries, though even its merits are qualified. For emerging markets economies, the "Greenspan-Guidotti" rule of 100 percent cover of external short-term debt is a widely used metric. However, full insurance against a sudden withdrawal of bank external short-term funding would require an impractically high level of foreign exchange reserves in advanced countries. For example, if the 100 percent rule is applied to bank short-term debts, the amount of required foreign exchange reserves would be 5.6 times Sweden's current holding: i.e., \$266 billion (58 percent of GDP), compared to \$ 47billion at end-2010. Furthermore, if all advanced economies were to pursue such a reserve adequacy strategy, there would be very considerable global over-insurance.

\section{A Liquidity Gap Approach}

10. For the Riksbank, important motives for holding foreign exchange reserves include: providing emergency liquidity assistance to banks, covering Sweden's share of the international lending by the IMF, and intervening foreign in exchange markets. However, the Riksbank's ability in mid-crisis to serve as lender of last resort in foreign currencies was 
constrained by the amount of foreign exchange reserves, including the government's ability to borrow externally. This establishes a simple intuition. The adequate level of foreign exchange reserves can be assessed by first, determining the maximum amount of banks' foreign exchange reserve needs under stress; second, estimating the probability of the stress events on these banks; and then extending these probability estimates to the joint probability of bank liquidity needs and the inability of the sovereign to borrow in mid-crisis to fund such bank liquidity needs. ${ }^{3}$

\section{Banks’ Foreign Exchange Reserve Needs}

11. Basel III has set new regulatory standards on liquidity. One is the Liquidity Coverage Ratio (LCR), which will ensure that banks have sufficient high quality liquid assets to survive a significant stress scenario lasting 30 days. The other is the Net Stable Funding Ratio (NSFR), which will ensure that long-term assets are funded with stable liabilities and banks can survive one year under market stress circumstances. ${ }^{4}$

12. If the LCR and NSFR are applied in each foreign currency, it would give a benchmark for assessing the maximum amount of foreign exchange reserve needs. By definition, the LCR and the NSFR will ensure that banks will survive for 30 days and one year, respectively, under stress circumstances in foreign exchange funding markets. Thus, opportunity costs for banks to meet the LCR and the NSFR can be considered as "liquidity insurance" that banks are required to pay for. If banks face difficulty in meeting these liquidity standards, even over time, as a policy option, the central bank/the government may share the liquidity insurance with banks by filling liquidity gaps in each currency. With this approach, the difference between actual and required liquidity gaps by currency gives an estimate of the maximum amount of foreign exchange reserves needs.

13. As an illustration, NSFR estimates are reported below based on the published information for each of four major Swedish banks. The analysis focuses on banks' US dollar assets and liabilities and euro assets and liabilities.

- $\quad$ First, examine the structure of major banks' US dollar and euro balance sheets. On the US dollar balance sheet, banks rely substantially on debt securities as their main

\footnotetext{
${ }^{3}$ There is a limited literature on reserve adequacy which focuses on advanced economies. Berg (2008) discussed the application of alternative reserve adequacy models to Swedish data. For general discussions about reserve adequacy, focusing on emerging market and low income countries, see International Monetary Fund (2011).

${ }^{4}$ The LCR is aimed at promoting the short-term resilience of the liquidity risk profile of banks by ensuring that they have sufficient high quality liquid assets to survive a significant stress scenario lasting 30 days. The LCR is expected to be met in a single currency and by each currency. The NSFR is aimed at promoting structural changes in the liquidity risk profiles of banks away from short-term funding mismatches and toward more stable longer-term funding of assets and business activities (Basel Committee on Banking Supervision, 2010).
} 
sources of funding and hold a large amount of non-US dollar assets (e.g. mortgages) converted through foreign exchange swaps. Detailed information on their maturity profiles is not available, but anecdotal information suggests that a large portion of the debt securities are in short-term and non-US dollar assets in longer-term, implying a maturity mismatch. On the euro balance sheet, banks rely less on debt securities and more on deposits and equity in funding and hold more securities in their assets. Thus, the degree of a maturity mismatch in the euro balance sheet could be considered moderate.
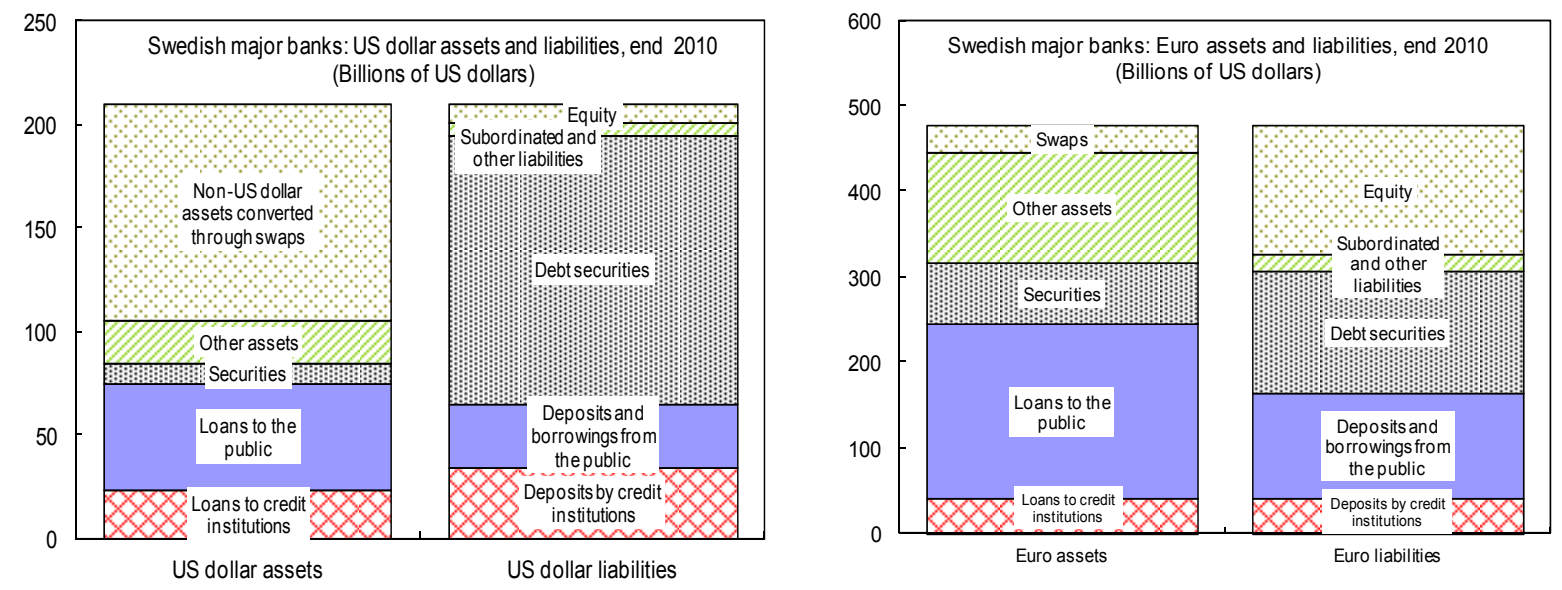

Source: Bank reports.

- $\quad$ Then, following the Basel III definition, estimate NSFRs on US dollar and euro balance sheets. The NSFR is defined as following.

$$
\text { NSFR }=\frac{\text { Available amount of stable funding }}{\text { Required amount of stable funding }}=\frac{\sum \text { Funding } \times \text { factor }}{\sum \text { Assets } \times \text { factor }}
$$

Importantly, it is assumed that in stress, banks will not be able to raise funding in foreign currencies. ${ }^{5}$ This could be considered as an extreme stress scenario, but the global crisis experience suggests that this is not an unlikely scenario. Detailed assumptions for the factors are summarized in Table 1.

14. The results suggest substantial funding gaps in the US dollar balance sheet, but not significant gaps in the euro balance sheet. The US dollar funding gap narrowed somewhat over the last three years - reflecting banks' efforts to extend the maturity of their debt funding - but remains substantial, ranging from $\$ 30$ billion to $\$ 70$ billion for the total of four major banks, depending on the assumptions made on the stability of funds and the liquidness of assets (Figure 3). The upper estimates significantly exceed the current level of foreign exchange reserves ( $\$ 50$ billon). By bank, Nordea is estimated to be exposed to large NSFR

\footnotetext{
${ }^{5}$ Even foreign currency swap markets are assumed to become defunct.
} 
gaps, given its extensive operations in Nordic economies. In contrast, the euro funding gap is estimated to be small or even zero with discount factors assumed in Table 1. This is mainly because euro-denominated debt securities have longer maturity-anecdotal evidence suggests that more than a half of euro-denominated debt securities have the maturity of over one year.

\section{The Probability of Loss of Access by Banks to Foreign Currency Funding}

15. There is no consensus on how to measure the probability of liquidity crisis. ${ }^{6}$ However, past experiences show that a bank solvency crisis in many cases followed a liquidity crisis — once investors recognize default risks in a bank, they stop rolling over their claims on the bank. Accordingly, the analysis below uses the probability of a default by a bank as a proxy for the probability that a bank is shut out from funding markets.

16. The probability of a liquidity crisis and its impact would depend on the sources of the initial shock. The global environment for Swedish banks remains uncertain, and concern about financial risk in several southern European economies is lingering. Accordingly, solely for purposes of illustration of the technical approach suggested here, a stress scenario is considered assuming that a European sovereign, which has experienced market pressures recently, becomes distressed, which leads to distress in Swedish banks, and Swedish banks are shut out from funding markets. Because the proxy focuses on solvency crises, it probably underestimates somewhat the risk of liquidity crises as these can also occur separately from solvency crises.

17. The measurement of probability follows Segoviano and Goodhart (2009)'s methodology. ${ }^{7}$ Their measurement is based on Credit Default Swap (CDS) spreads and equity prices for the four major Swedish banks, Sweden, and the selected European sovereign. The distress dependence matrix — which illustrates market perceptions on pairwise conditional probabilities of distress - shows that Swedish banks' risks with the European sovereign used in this exercise rose sharply in the spring of 2009, but have since come down to a lower level (Table 2 and below text figure). The probability that all Swedish banks become distressed given stress in the European sovereign also reached highs at 0.4 in mid 2009, but now is low.

\footnotetext{
${ }^{6}$ For example, some literature suggests that a crisis could be self-fulfilling and triggered by "sunspot" variables (see Jeanne and Rancière, 2006).

7 The probability indicators, which are calculated following Segoviano and Goodhart (2009) based on CDS spreads, measure the probability of distress of a bank or an economy in interest. However, Thus the assumption that a liquidity crisis would simultaneously lead to a banking crisis may not be a strong one. Furthermore, it is assumed that the measurement of the probability of liquidity crisis indicates.
} 

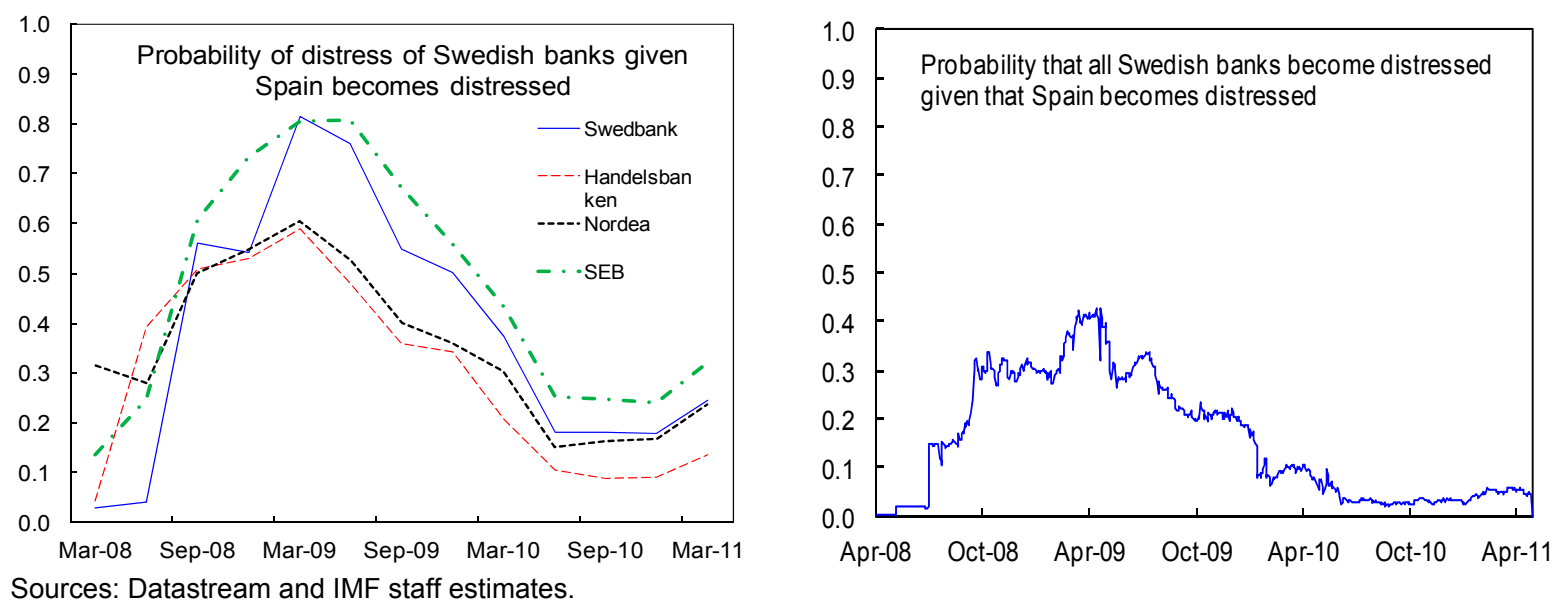

\section{Combining Liquidity Gaps with Probability of Stress Events}

18. The final steps are to trace through the implications - in this illustrative case- for the Swedish banking system using a "decision tree" structure. ${ }^{8}$

19. In September 2008, given the assumed originating stress event, the probability that Swedbank faces liquidity risk is estimated at 0.56 (Figure 4 , the top figure). Swedbank's NSFR gap in US dollar suggests the funding gap of $\$ 10$ billion. ${ }^{9}$ This in turn implies that to prevent Swedbank from a US dollar funding shortage, the central bank needs to hold $\$ 10$ billion in foreign exchange reserves to support Swedbank, with the probability of 0.56 (Figure 4).

20. Then, moving to the next stage of the tree, the probability of both Swedbank and Nordea becoming distressed is estimated at 0.36 . Thus, given their funding gaps of $\$ 33$ billion in total, the central bank needs to hold foreign exchange reserves of $\$ 33$ billion with the probability of 0.36 .

21. In a similar way, the combinations of NSFR gaps and the probability are calculated for September 2008, March 2009, March 2010, and March 2011, and are summarized in Figure 5.

\footnotetext{
${ }^{8}$ This is an illustrative example. A similar exercise could be carried out with other countries, as trigger countries.

${ }^{9}$ The average of the upper and lower bounds estimates in Figure 3 are used for this illustrative calculations.
} 
22. The analysis suggests that foreign exchange reserve needs rose sharply in 2008-09. In March 2009, foreign exchange reserve needs rose sharply, as Swedish banks' creditworthiness deteriorated, in part due to their exposure to Baltics and in part due to spillover effects from financial market fragilities in the euro area. For example, foreign exchange reserve needs in the case of stress in the selected European sovereign were $\$ 18$ billion in September 2008 with the probability of 0.5 and increased to $\$ 50$ billion in

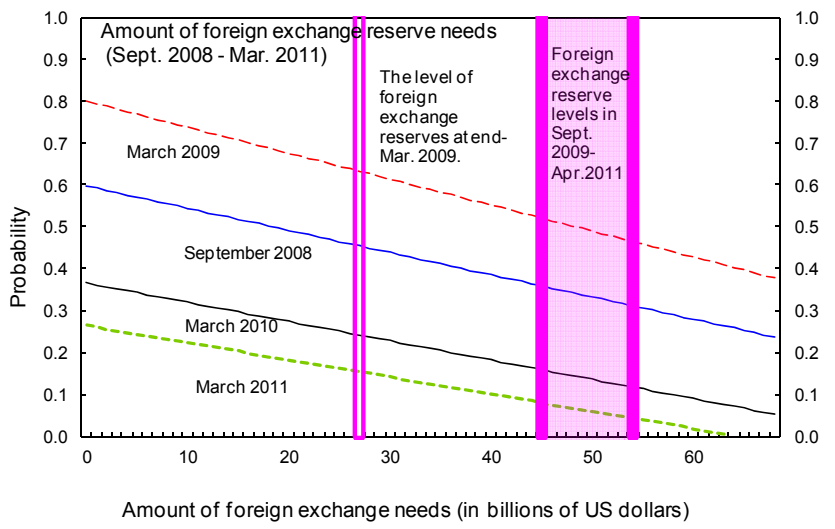
March 2009, well beyond the level of foreign exchange reserve holding at that time ( $\$ 27$ billion). In the middle of 2009 , the authorities decided to raise foreign exchange reserves to over $\$ 50$ billion, which in retrospect, is consistent with the increased foreign exchange reserve needs suggested by this analysis.

23. The analysis is next extended to incorporate Sweden's sovereign risk. The central bank does not need to hold precautionary foreign exchange reserves in anticipation of liquidity crisis, provided that it can maintain market access to borrow foreign currencies and boost foreign exchange reserves any time under any market circumstances. However, once large banks become distressed, markets may raise concern about the government's ability to resolve banking problems, as bank resolution could involve large public finance resources. Under such circumstances, the government itself could face a large increase in funding costs.

24. The results of combining bank and sovereign stress are summarized in Figures 4 and 6. ${ }^{10}$ The results show that taking account of Swedish sovereign risk, the probability of significant foreign exchange reserve needs is estimated to be low, except in March 2009. At that time, Sweden's sovereign itself was affected severely: the probability of Sweden sovereign distress was $0.1-0.2$ for a single bank stress, but rose to $0.3-0.4$ if two or three banks became stressed.

\footnotetext{
10 The calculation steps are exactly the same as the previous case where Sweden's sovereign is not taken account, for example, in September 2008, given Swedbank's distress, the probability that Sweden sovereign becomes distressed-the government itself would lose market access distress-was 0.1 (Figure 4). Then, combining the probability that Swedbank becomes distressed (0.56), the probability that both Swedbank and Sweden sovereign become distressed is estimated at $0.06(=0.56 \times 0.1)$. This in turn implies the central bank needs to hold $\$ 10$ billion in foreign exchange reserves to support Swedbank, with the probability of 0.06, taking account of the risk that the government itself would lose market access.
} 


\section{Concluding Observations}

25. The analysis above highlights that foreign exchange reserve needs evolve over time. This reflects the systemic linkage between banks, and between banks and the sovereign. Sweden's sovereign strength itself was affected at the height of the severe stress in March 2009, suggesting that there was risk that the government itself could have been shut out of funding markets.

26. This underscores the need for active foreign exchange reserve management using the formal tools suggested and illustrated here. The analysis suggests that the current level of foreign exchange reserves ( $\$ 50$ billion) is enough to meet foreign liquidity needs even under the unlikely event of distress in the European sovereign considered, given that currently market perceptions about Swedish banks creditworthiness and Sweden sovereign strength are relatively favorable.

27. However, all elements of these calculations can evolve quickly: banks' liquidity positions can adjust rapidly; and market perceptions about the impact of any particular foreign stress event could do likewise. Accordingly, the authorities should frequently review the range of possible external stress events-for example, which country could be a trigger (as it may not be the particular European sovereign considered here), and how they affect Sweden directly and indirectly-that they consider in exercises such as this. These may even, in some circumstances, need to be accompanied by consideration of purely domestic stress events.

28. In addition, to ensure the effectiveness of foreign exchange reserve policy, the governance framework on foreign exchange reserve management policy, should also be reviewed urgently. 


\section{References}

Basel Committee on Banking and Supervision, 2010, Basel III: International Framework for Liquidity Risk Management, Standards, and Monitoring, December.

Berg, Claes, 2008, "Global financial crisis: Which are the consequences for FX management by Central Banks in an Insurance Perspective?" presented at Bank of Thailand's

International Symposium "Financial Globalization and Emerging Market Economies" in Bangkok 7-8 November 2008:

International Monetary Fund, 2011, “Assessing Reserve Adequacy, ” February, http://www.imf.org/external/np/pp/eng/2011/021411b.pdf

Jeanne, O. and R. Rancière, 2006, "The Optimal Level of International Reserves for Emerging Market Countries: Formulas and Applications," IMF Working Paper, October, WP/06/229.

Segoviano, M. A. and C. C. Goodhart, 2009, "Banking Stability Measures,” IMF Working Paper, January, WP/09/4. 
Table 1. Assumptions for NSFR Factors

\begin{tabular}{|c|c|c|c|c|c|}
\hline \multicolumn{3}{|c|}{ Funding (stability of funding) } & \multicolumn{3}{|c|}{ Assets (liquidness of assets) } \\
\hline \multirow[t]{2}{*}{ Item } & \multicolumn{2}{|c|}{ Factor1/ } & \multirow{2}{*}{ Item } & \multicolumn{2}{|c|}{ Factor1/ } \\
\hline & $\mathrm{U}$ & $\mathrm{L}$ & & $\mathrm{U}$ & $\bar{L}$ \\
\hline Deposits by credit institutions $2 /$ & 0.0 & 0.0 & Loans to credit institutions $2 /$ & 0.0 & 0.0 \\
\hline Deposits from the public $3 /$ & 0.5 & 0.9 & Loans to the public $2 /$ & 0.85 & 0.85 \\
\hline Debt securities in issue 4/ & & & Securities 2/ & 0.5 & 0.05 \\
\hline In US dollars & 0.2 & 0.2 & & & \\
\hline In euro & 0.6 & 0.6 & & & \\
\hline Subordinated and other liabilities & & & Other assets $5 /$ & 0.2 & 0.0 \\
\hline In US dollars & 0.2 & 0.2 & & & \\
\hline In euro & 0.6 & 0.6 & & & \\
\hline Equity 2/ & 1.0 & 1.0 & $\begin{array}{l}\text { Non-US dollar (or euro) assets } \\
\text { covered by swaps } 6 /\end{array}$ & 0.65 & 0.5 \\
\hline
\end{tabular}

$1 /$ "U" refers to factors used for estimating a NSFR upper bound, and "L" refers to factors used for estimating a NSFR lower bound.

2/ Consistent with Riksbank (2010) and the BCBS (2010).

3/ The stability of deposits ranges from 0.5-0.9 depending on the type of depositors, as assumed by Riksbank (2010) and BCBS (2010).

4/ Based on anecdotal evidence.

5/ Consist mostly of Nordea's short-term claims on securities settlement proceeds.

6/ Assumed mortgage assets, for which BCBS assume the discount ratio of 0.65. 


\section{Table 2. Swedish Banks and Selected European Sovereign Distress Dependence Matrix \\ (In probability)}

\begin{tabular}{|c|c|c|c|c|c|c|c|c|c|c|}
\hline 1-Aug-08 & $\begin{array}{l}\text { Swed- } \\
\text { bank }\end{array}$ & $\begin{array}{c}\text { Handels- } \\
\text { banken }\end{array}$ & Nordea & SEB & Greece & Ireland & Italy & Portugal & Spain & Average \\
\hline Swedbank & 1.00 & 0.37 & 0.41 & 0.32 & 0.10 & 0.19 & 0.41 & 0.23 & 0.35 & 0.25 \\
\hline Handelsbanken & 0.31 & 1.00 & 0.54 & 0.27 & 0.10 & 0.18 & 0.47 & 0.24 & 0.40 & 0.28 \\
\hline Nordea & 0.28 & 0.44 & 1.00 & 0.22 & 0.08 & 0.16 & 0.40 & 0.21 & 0.37 & 0.24 \\
\hline SEB & 0.72 & 0.70 & 0.72 & 1.00 & 0.19 & 0.33 & 0.65 & 0.39 & 0.60 & 0.43 \\
\hline $\begin{array}{l}\text { Colum average } \\
\text { (excluding own effects) }\end{array}$ & 0.44 & 0.50 & 0.56 & 0.27 & 0.12 & 0.22 & 0.48 & 0.27 & 0.43 & 0.30 \\
\hline 1-Apr-09 & $\begin{array}{l}\text { Swed- } \\
\text { bank }\end{array}$ & $\begin{array}{l}\text { Handels- } \\
\text { banken }\end{array}$ & Nordea & SEB & Greece & Ireland & Italy & Portugal & Spain & Average \\
\hline Swedbank & 1.00 & 0.84 & 0.85 & 0.81 & 0.50 & 0.63 & 0.84 & 0.75 & 0.84 & 0.71 \\
\hline Handelsbanken & 0.36 & 1.00 & 0.63 & 0.41 & 0.29 & 0.36 & 0.58 & 0.50 & 0.60 & 0.47 \\
\hline Nordea & 0.37 & 0.64 & 1.00 & 0.41 & 0.29 & 0.37 & 0.58 & 0.50 & 0.62 & 0.47 \\
\hline SEB & 0.72 & 0.85 & 0.85 & 1.00 & 0.47 & 0.59 & 0.81 & 0.72 & 0.83 & 0.68 \\
\hline $\begin{array}{l}\text { Colum average } \\
\text { (excluding own effects) }\end{array}$ & 0.48 & 0.78 & 0.78 & 0.54 & 0.39 & 0.49 & 0.70 & 0.62 & 0.72 & 0.58 \\
\hline 1-Apr-10 & $\begin{array}{l}\text { Swed- } \\
\text { bank }\end{array}$ & $\begin{array}{l}\text { Handels- } \\
\text { banken }\end{array}$ & Nordea & SEB & Greece & Ireland & Italy & Portugal & Spain & Average \\
\hline Swedbank & 1.00 & 0.55 & 0.52 & 0.50 & 0.11 & 0.25 & 0.39 & 0.28 & 0.38 & 0.28 \\
\hline Handelsbanken & 0.21 & 1.00 & 0.37 & 0.22 & 0.05 & 0.13 & 0.21 & 0.14 & 0.21 & 0.15 \\
\hline Nordea & 0.30 & 0.57 & 1.00 & 0.31 & 0.07 & 0.18 & 0.30 & 0.21 & 0.31 & 0.21 \\
\hline SEB & 0.58 & 0.67 & 0.62 & 1.00 & 0.13 & 0.28 & 0.44 & 0.31 & 0.44 & 0.32 \\
\hline $\begin{array}{l}\text { Colum average } \\
\text { (excluding own effects) }\end{array}$ & 0.36 & 0.60 & 0.51 & 0.34 & 0.09 & 0.21 & 0.33 & 0.23 & 0.33 & 0.24 \\
\hline 1-Apr-11 & $\begin{array}{l}\text { Swed- } \\
\text { bank }\end{array}$ & $\begin{array}{l}\text { Handels- } \\
\text { banken }\end{array}$ & Nordea & SEB & Greece & Ireland & Italy & Portugal & Spain & Average \\
\hline Swedbank & 1.00 & 0.27 & 0.25 & 0.30 & 0.04 & 0.07 & 0.19 & 0.08 & 0.14 & 0.10 \\
\hline Handelsbanken & 0.12 & 1.00 & 0.22 & 0.14 & 0.02 & 0.03 & 0.13 & 0.04 & 0.09 & 0.06 \\
\hline Nordea & 0.20 & 0.39 & 1.00 & 0.21 & 0.04 & 0.06 & 0.20 & 0.07 & 0.15 & 0.10 \\
\hline SEB & 0.41 & 0.41 & 0.36 & 1.00 & 0.06 & 0.09 & 0.24 & 0.10 & 0.18 & 0.13 \\
\hline $\begin{array}{l}\text { Colum average } \\
\text { (excluding own effects) }\end{array}$ & 0.25 & 0.36 & 0.28 & 0.22 & 0.04 & 0.06 & 0.19 & 0.07 & 0.14 & 0.10 \\
\hline
\end{tabular}

Sources: Datastream and author's calculation following M. Segoviano and C. Goodhart (2009)'s methodology. 
Figure 1. Reserve Coverage, $2000-10$
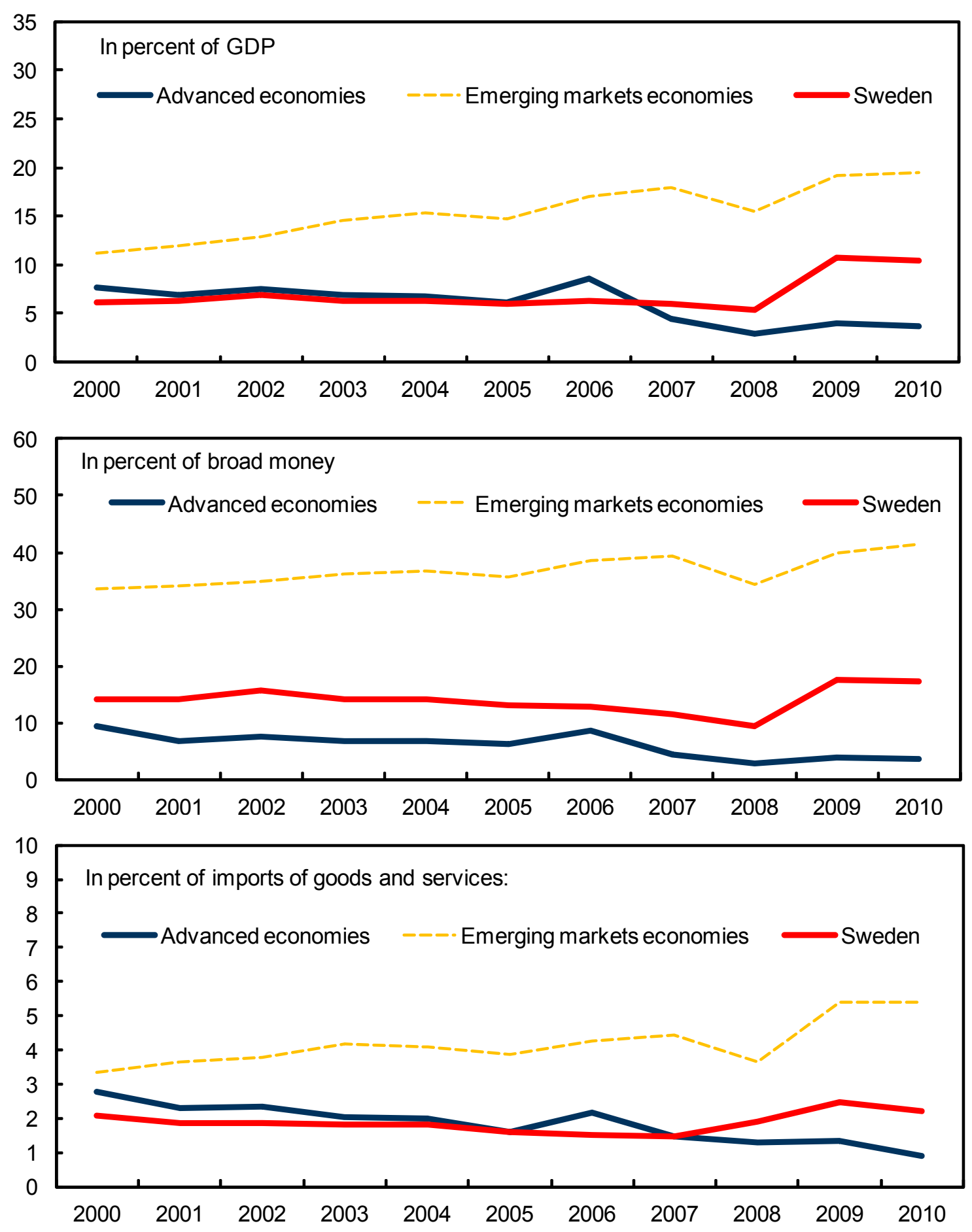

Source: IMF World Economic Outlook database; and World Bank/IMF/BIS External Debt database. 
Figure 2. Advanced Economies: Foreign Exchange Reserves, End-2010
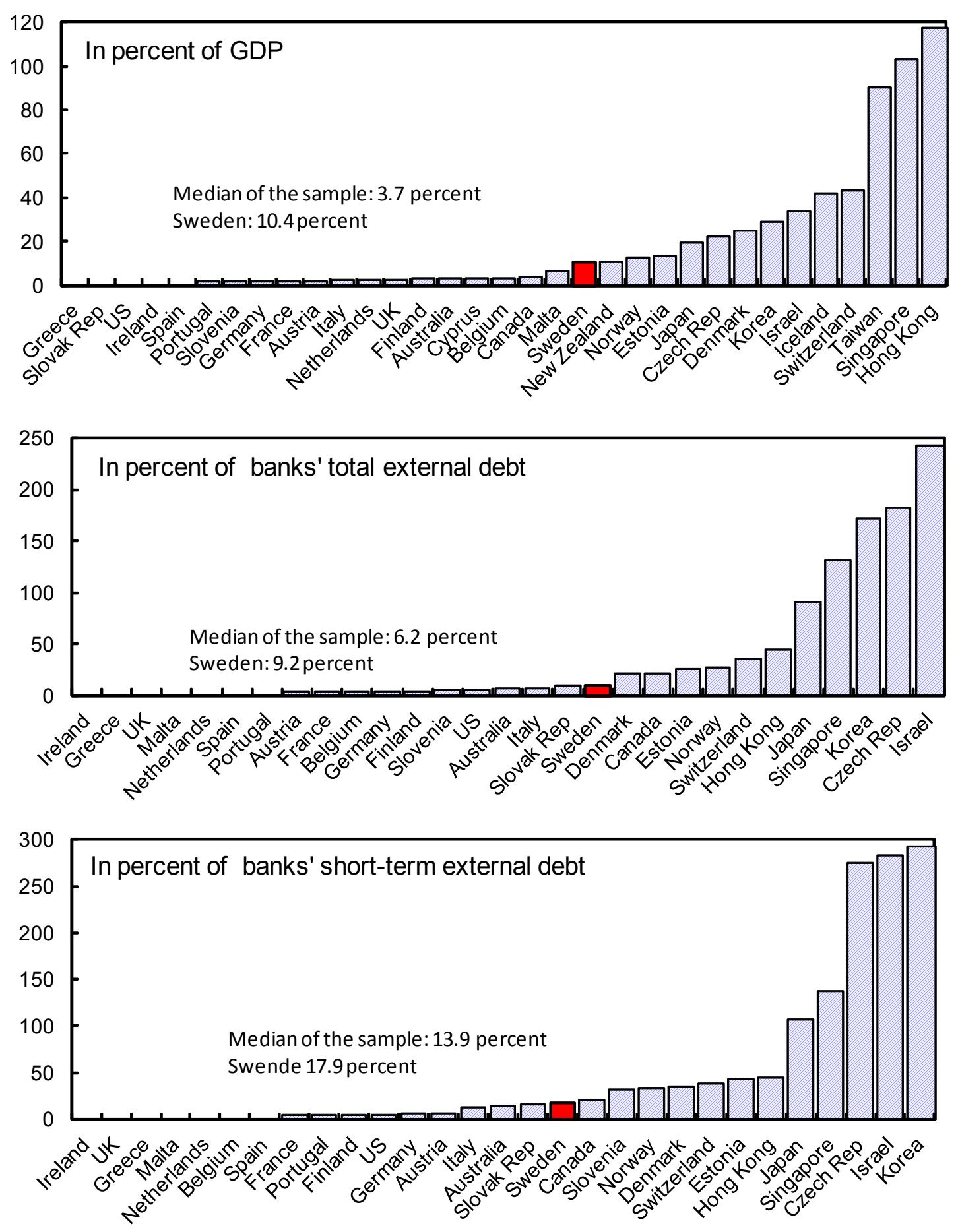

Sources: IMF World Economic Outlook database; and World Bank/IMF/BIS External Debt database. 
Figure 3. Swedish Major Banks: US Dollar Funding Gaps, 2008-09 (In billions of US dollars)
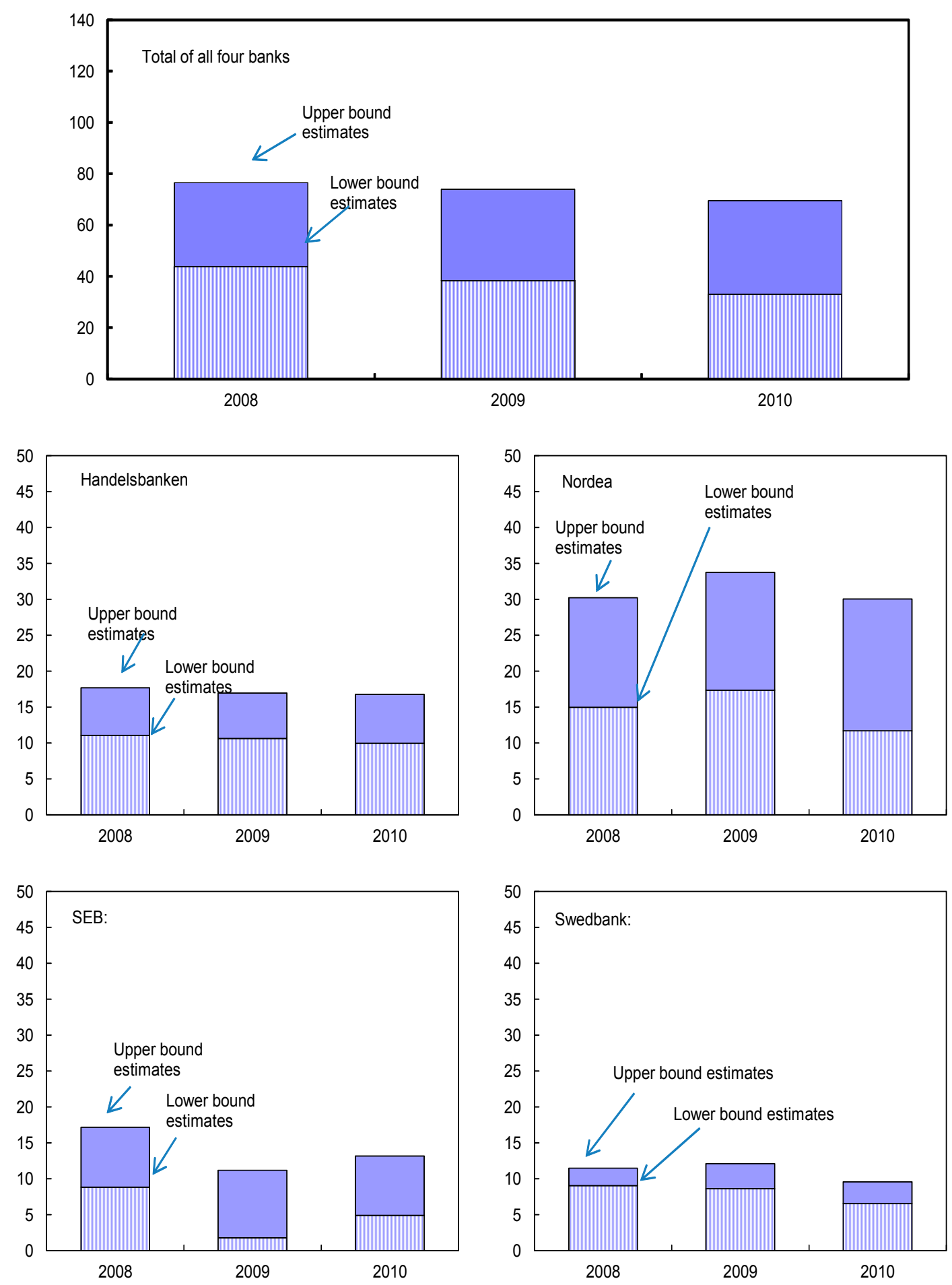

Sources: Bank annual reports; Haver; and Fund staff estimates. 
Figure 4. Estimating the Foreign Exchange Reserve Needs by Probability

(September 2008)

\begin{tabular}{|lc|}
\hline \multicolumn{2}{|c|}{ Bank(s) } \\
\hline $\begin{array}{l}\text { Funding gap (in } \\
\text { billions of US dollar) }\end{array}$ & $\begin{array}{c}\text { Bank(s) distress } \\
\text { probability } \\
\text { Bank(s) distress } \\
\text { probability } \times \text { sovereign }\end{array}$ \\
\hline
\end{tabular}

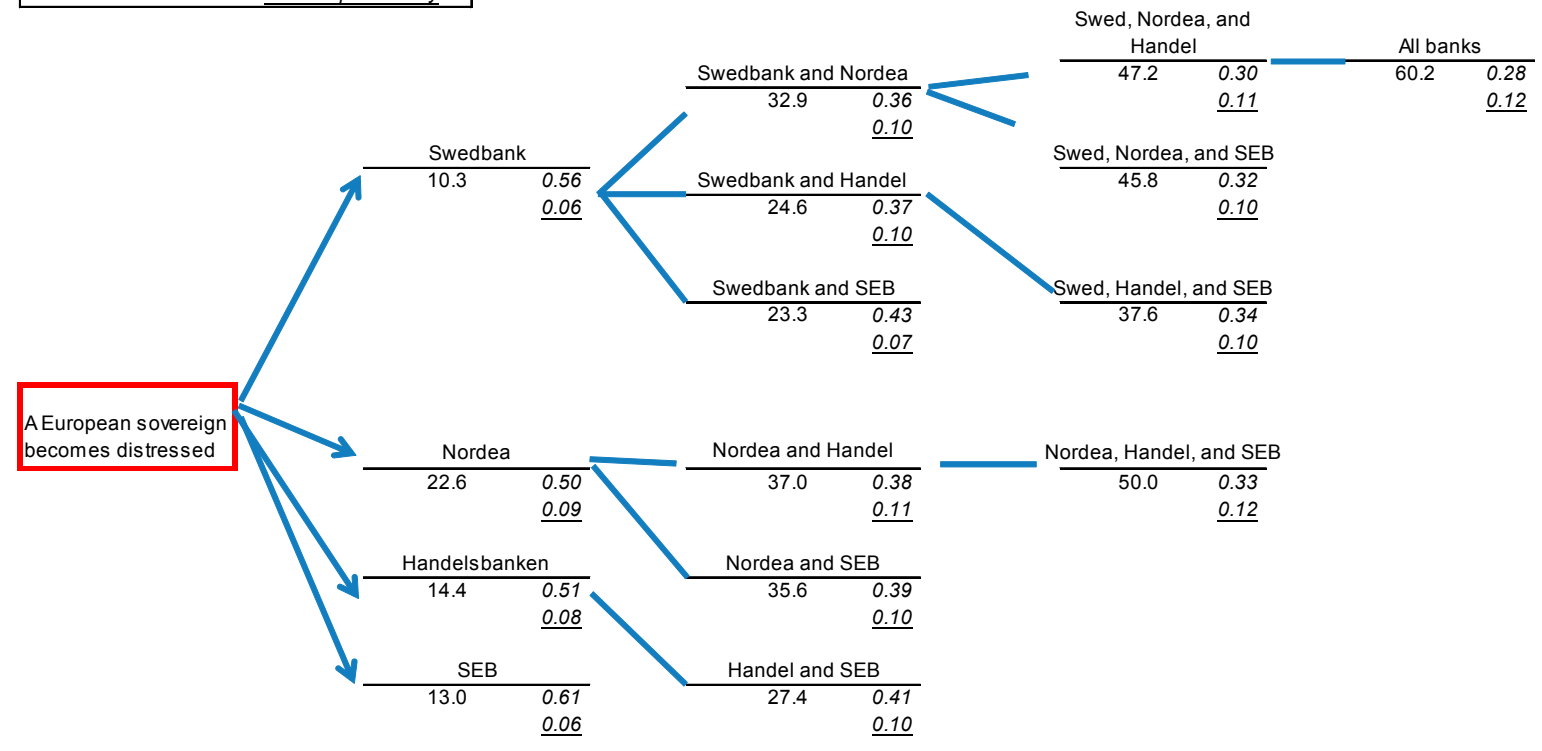

(March 2009)

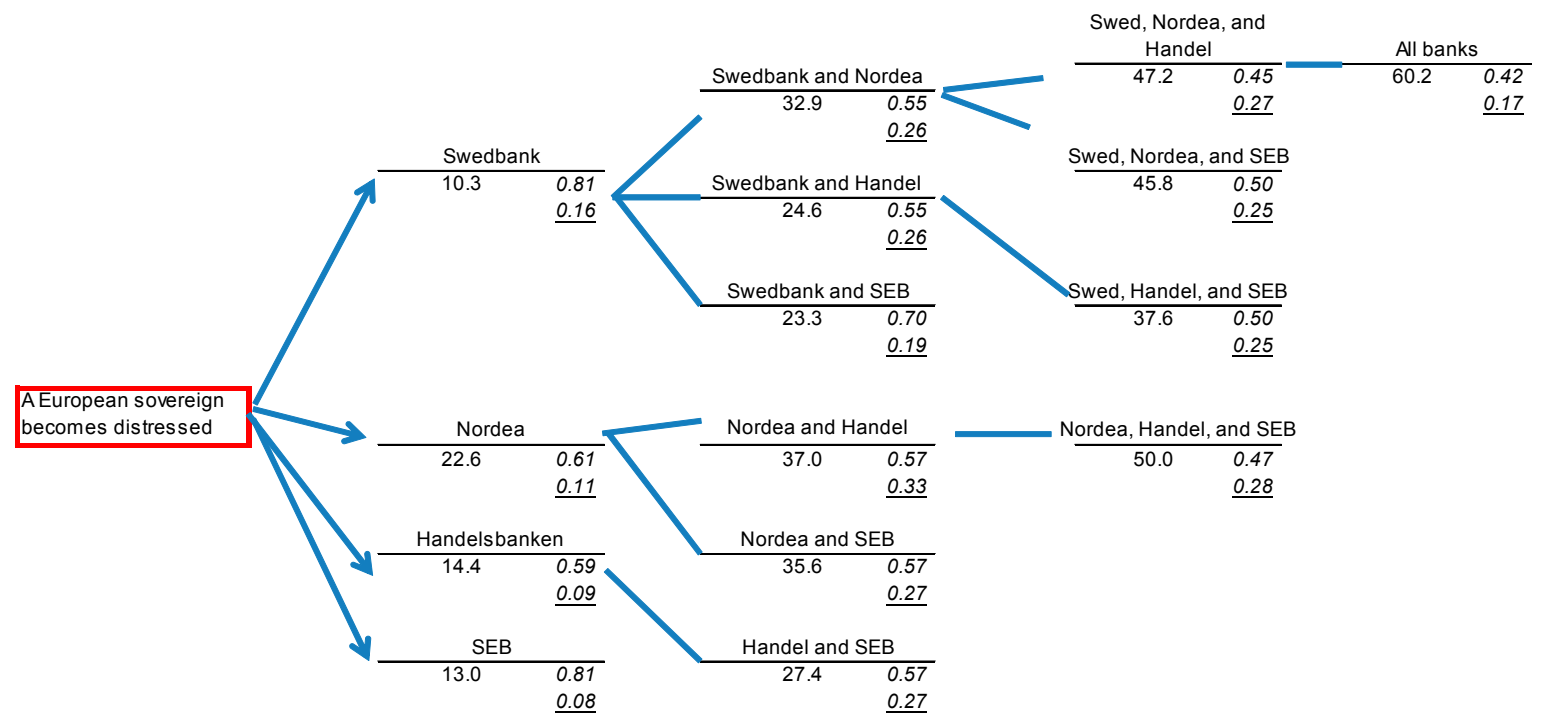

Source: IMF staff estimates. 


\section{Figure 4. Estimating the Foreign Exchange Reserve Needs by Probability} (continued)

\section{(March 2010)}

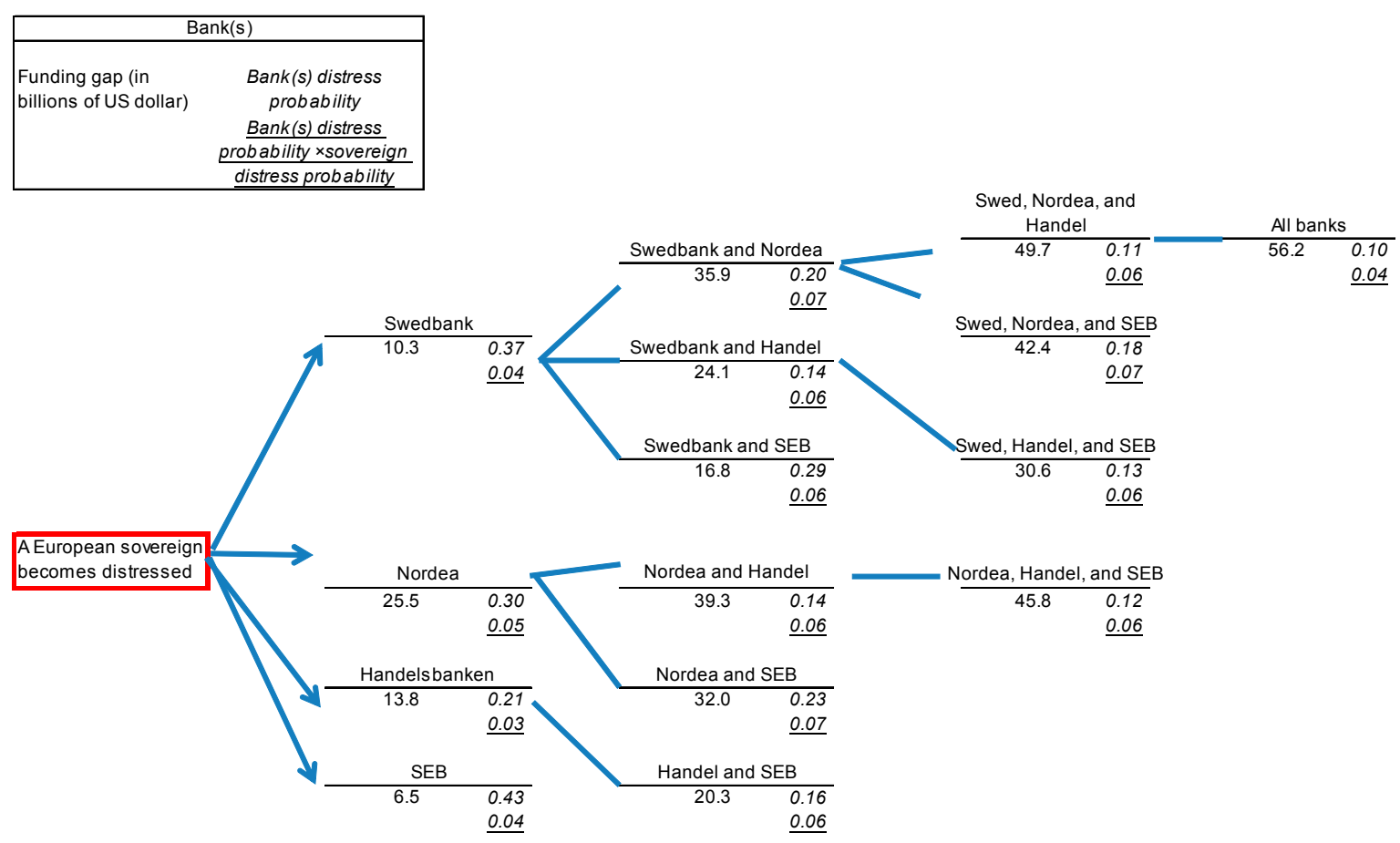

(March 2011)

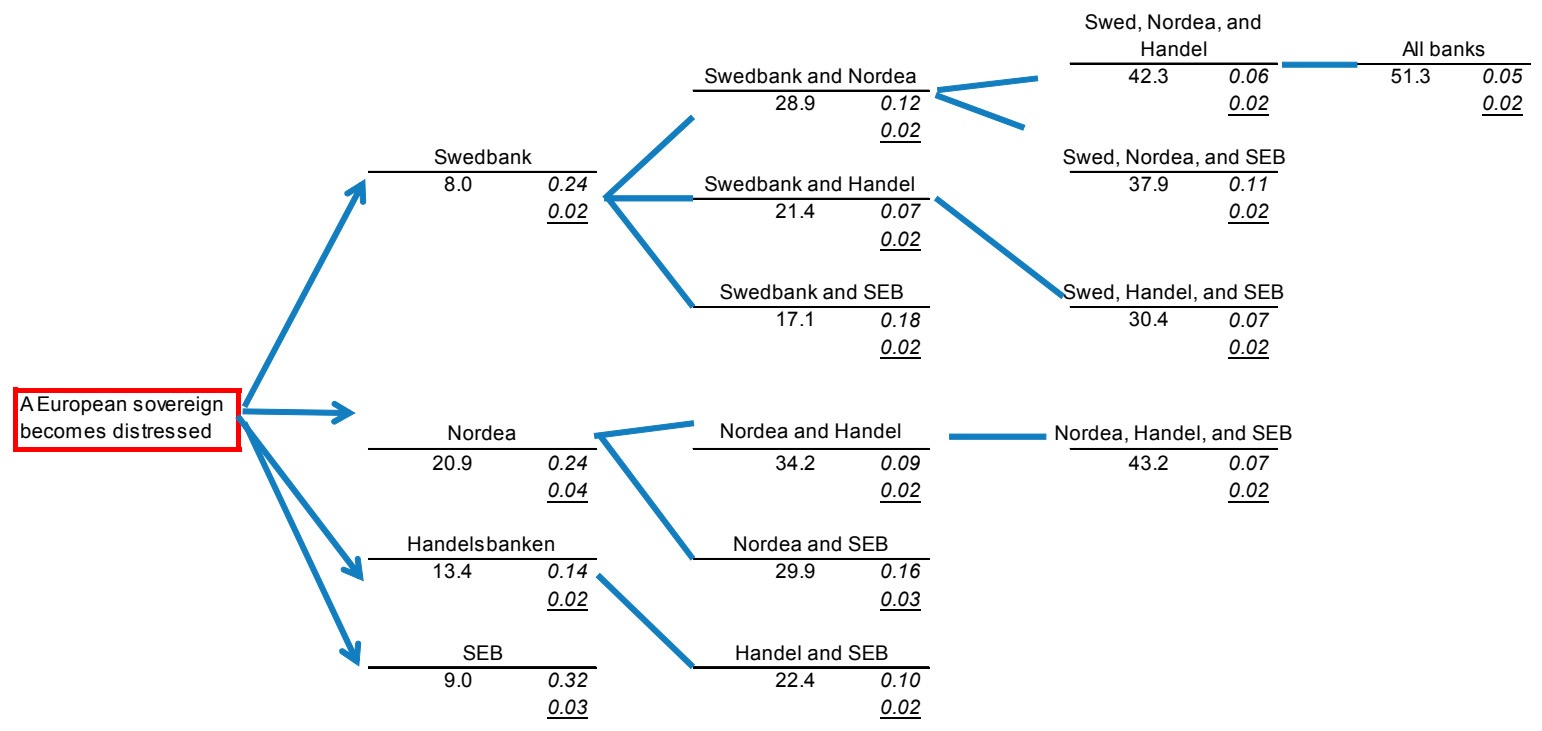

Source: IMF staff estimates. 
Figure 5. Estimated Foreign Exchange Reserve Needs by Probability (Without assuming Sweden sovereign risk)
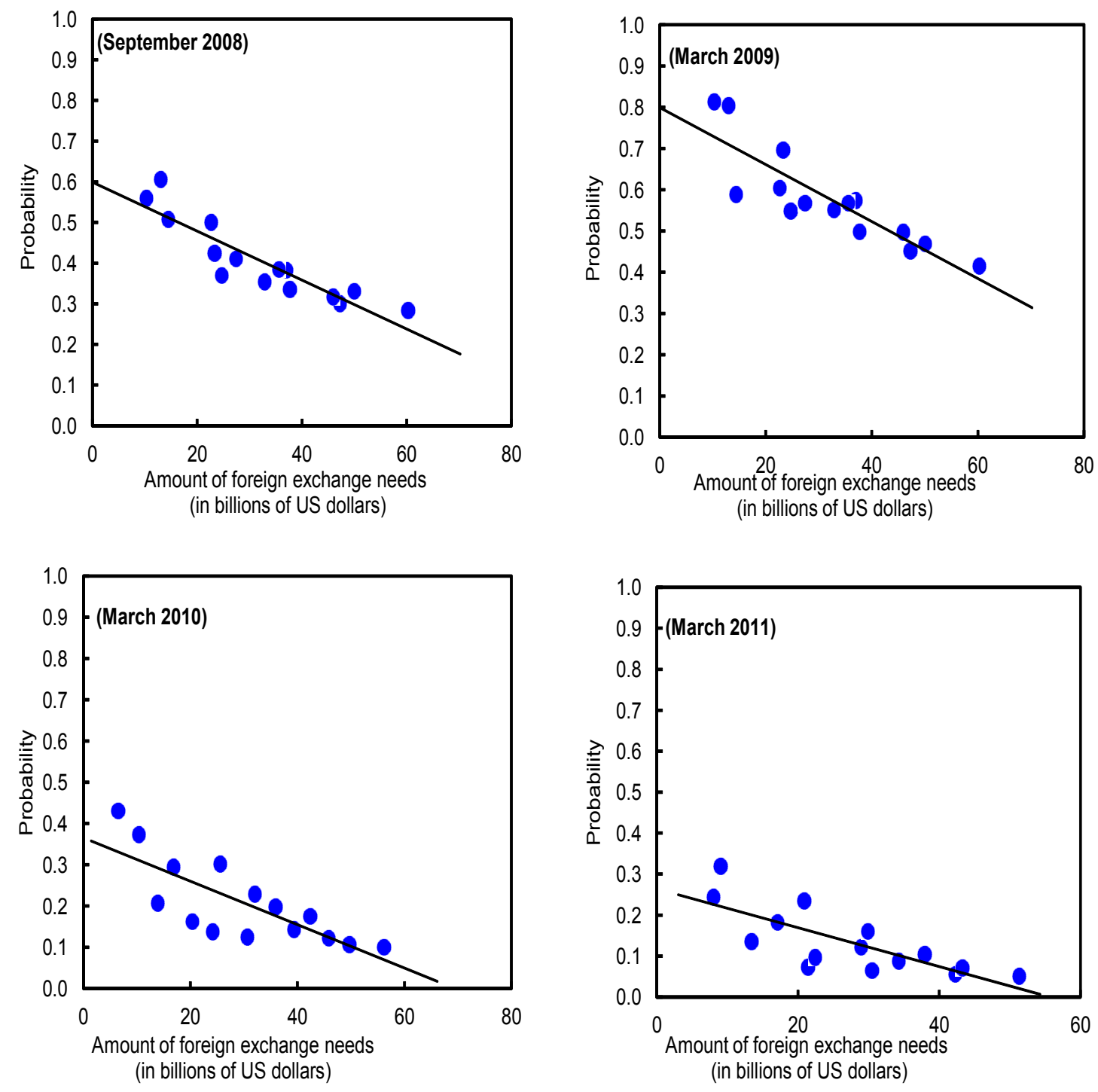

Source: IMF staff estimates. 
Figure 6. Estimated Foreign Exchange Reserve Needs by Probability (Assuming Sweden sovereign risk)
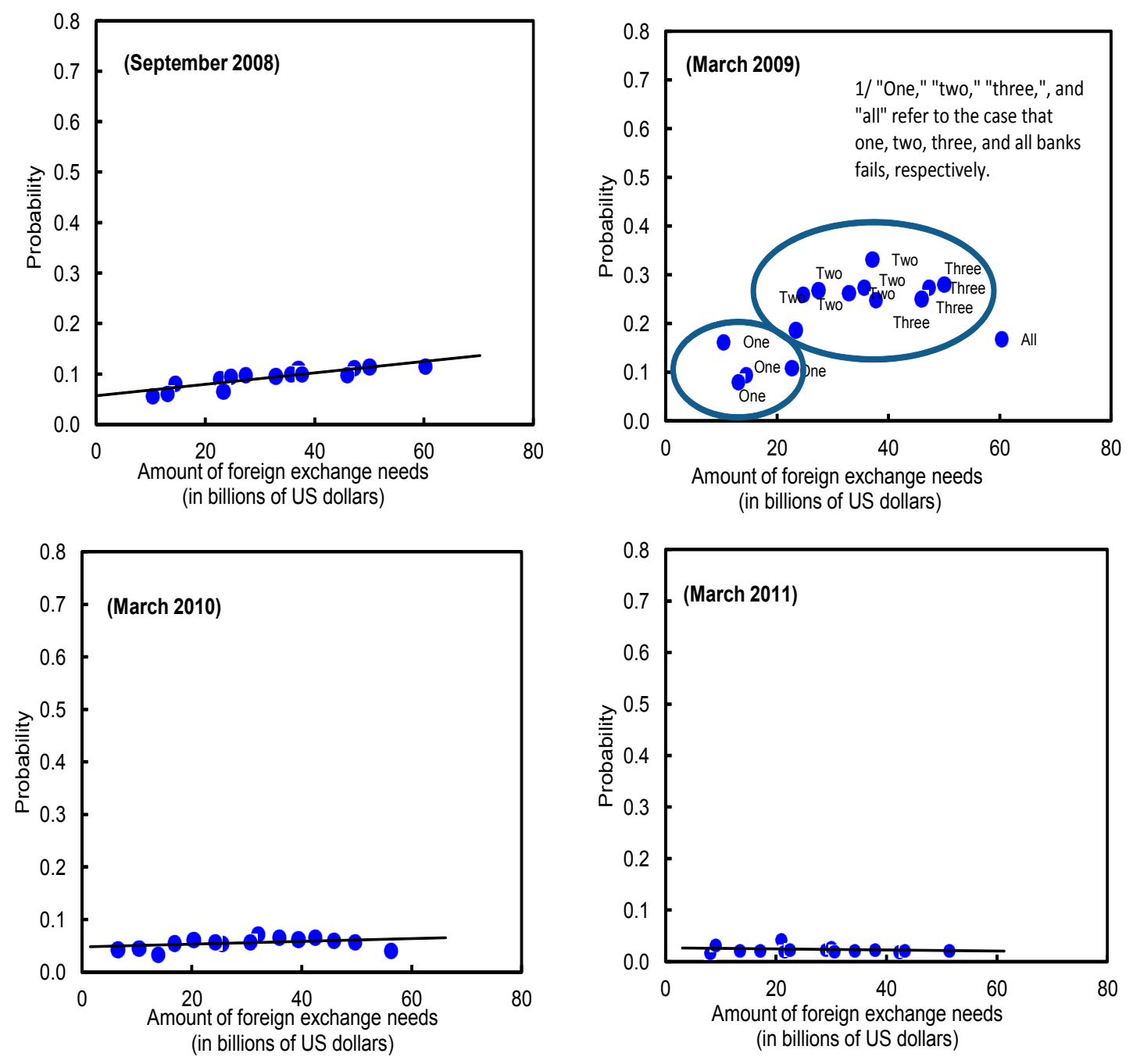

Source: IMF staff estimates. 


\section{INTERNATIONAL MONETARY FUND SWEDEN}

Staff Report for the 2011 Article IV Consultation-Informational Annex

Prepared by the Staff Representatives for the 2011 Consultation with Sweden

(In consultation with other departments)

June 24, 2011

Contents

Page

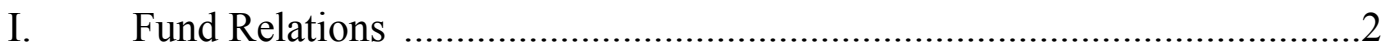


AnNex I. SWEdEn: Fund Relations

(As of May 31, 2011)

I. Membership Status: Joined 08/31/1951

$\underline{\text { Article VIII }}$

II. General Resources Account:

SDR Million

Percent of Quota

Quota

2,395.50

100.00

Fund holdings of currency (Exchange Rate)

$1,785.00$

74.51

Reserve tranche position

610.50

25.49

Lending to the Fund

New Arrangements to Borrow

261.35

III. SDR Department:

SDR Million Percent of Allocation

Net cumulative allocation

$2,248.96$

100.00

Holdings

$2,252.92$

100.18

IV. Outstanding Purchases and Loans: None

V. Latest Financial Arrangements: None

VI. Projected Obligations to Fund: ${ }^{1 /}$

(SDR Million; based on existing use of resources and present holdings of SDRs):

Forthcoming

Principle

$\begin{array}{lllll}\text { Charges/Interest } & 0.03 & 0.03 & 0.03 & 0.03\end{array}$

Total

$\begin{array}{llll}0.03 & 0.03 & 0.03 & 0.03\end{array}$

1/ When a member has overdue financial obligations outstanding for more than three months, the amount of such arrears will be shown in this section.

VII. Exchange Arrangements: The Krona has been floating freely since November 19, 1992. Sweden has accepted the obligations of Article VIII (Sections 2(a), 3, and 4) and maintains an exchange system free of restrictions on payments and transfers for current international transactions, apart from those imposed for security reasons, as notified to the Fund by the Riksbank (EBD/06/79, June 23, 2006) in accordance with Executive Board Decision No.144-(52/51). 
VIII. 2011 Article IV Consultation: A staff team comprising P. Doyle (head, EUR), R. Babihuga, K. Ishi (EUR), and Borja Gracia (FAD) visited Stockholm during May 19-June 1, 2011 to conduct the consultation discussions. Mr. Holmberg, Advisor to Sweden's Executive Director, also attended the mission.

Outreach: The team met with the parliamentary finance committee, representatives of the private sector, the labor union, the manufacturing association, the four largest banks, think tanks, and the Fiscal Policy Council.

Press conference: The mission held a press conference in the Riksbank after the concluding meeting.

Publication: The staff report will be published.

Last Article IV Consultation: Discussions for the 2010 Article IV consultation were held in Stockholm on May 27-June 8, 2010 and the staff report was issued on July 2010 (IMF Country Report 10/220). The consultation was concluded by the Executive Board on July 14, 2010.

IX. Technical Assistance: In connection with the 2007 Article IV consultation, LEG and MCM provided technical assistance on bank resolution frameworks (Aide Memoire, March 16, 2007). Sweden has made significant progress in addressing deficiencies in its AML/CFT framework identified by the Financial Action Task Force (FATF) in 2006. Preventive measures for financial institutions have been strengthened, including with respect to customer due diligence and the reporting of suspicious transactions. As a result, in October 2010 the FATF removed Sweden from its regular follow-up process. Going forward, the AML/CFT framework could be enhanced by enabling the freezing of all funds in cases of terrorism financing, and by improving beneficial ownership data on legal persons.

X. Resident Representative: None 


\section{INTERNATIONAL MONETARY FUND}

EXTERNAL

RELATIONS

Public Information Notice

DEPARTMENT

Public Information Notice (PIN) No. 11/88

FOR IMMEDIATE RELEASE

July 13,2011
International Monetary Fund

$70019^{\text {th }}$ Street, NW

Washington, D. C. 20431 USA

\section{IMF Executive Board Concludes 2011 Article IV Consultation with Sweden}

On July 8, 2011, the Executive Board of the International Monetary Fund (IMF) concluded the Article IV consultation with Sweden. ${ }^{1}$

\section{Background}

Sweden's recovery from the global recession has been very strong relative to other advanced countries. In 2010 , output rose by $51 / 2$ percent, with exports, investment, and consumption all rising rapidly. Unemployment has come down to $73 / 4$ percent, from its mid-crisis peak of over 9 percent, and core inflation has remained close to target throughout. Financial sector strains have been contained, bank capital and liquidity have strengthened, and most emergency stabilization measures have been withdrawn.

The fiscal deficit narrowed to 0.3 percent of GDP in 2010 and while public debt remains at about 40 percent of GDP, it is expected to fall. Alongside, a cautious monetary tightening cycle has been underway since July 2010 , with the Riksbank raising the policy rate by $13 / 4$ percentage points, together with prudential mortgage regulations to cool housing. Since its trough in mid2009 , the krona has appreciated by 20 percent against the euro, but remains competitive.

\footnotetext{
${ }^{1}$ Under Article IV of the IMF's Articles of Agreement, the IMF holds bilateral discussions with members, usually every year. A staff team visits the country, collects economic and financial information, and discusses with officials the country's economic developments and policies. On return to headquarters, the staff prepares a report, which forms the basis for discussion by the Executive Board. At the conclusion of the discussion, the Managing Director, as Chairman of the Board, summarizes the views of Executive Directors, and this summary is transmitted to the country's authorities. An explanation of any qualifiers used in summings up can be found here: http://www.imf.org/external/np/sec/misc/qualifiers.htm.
} 
Growth momentum has been maintained into 2011 with first quarter GDP rising by $61 / 2$ percent year-on-year. This success reflects the strength of domestic and global stabilization policies.

However, long-term and youth unemployment have lagged in the recovery, and fixed investment, although rising again, is still below 2006-08 levels relative to output. Furthermore, there is risk of a decline in house prices in coming years which could have an adverse impact on growth.

\section{Executive Board Assessment}

Executive Directors commended Sweden's impressive recovery from the global recession, noting that its economic growth in $\mathbf{2 0 1 0}$ was uniquely strong among advanced countries. This performance reflects decisive domestic policies, underpinned by sound policy frameworks.

Directors welcomed the measured exit from policy stimulus. The increases in the Riksbank policy rate confirm the commitment to low inflation. The withdrawal of many financial sector support measures alongside enhanced capital ratios has strengthened the resilience of the sector. The return to fiscal surpluses has reinforced strong sovereign credentials.

Directors noted that notwithstanding the positive outlook, challenges remain. Youth and longterm unemployment has lagged the recovery, fixed investment has remained below its pre-crisis level relative to GDP, and despite the recent dip in house prices, they still appear richly valued in the context of elevated household indebtedness. While the global economic outlook has improved, risks remain, especially from ongoing stresses in the euro area.

Directors commended the balance that the authorities had secured in their 2011 budget between supporting activity by maintaining a neutral stance given the remaining output gap, and continuing to build fiscal buffers against external uncertainties. In this regard, they welcomed the increased margins relative to spending ceilings and the postponement of planned tax reductions. Directors agreed that if scope remains for reductions in 2012, the focus should be on the earned income tax credit to strengthen labor market performance. Directors welcomed the role that the Fiscal Policy Council is playing as an effective watchdog. Going forward, it will be important to ensure that the Council remains adequately resourced.

Directors noted that continued moderation in wage settlements would provide a platform to secure a sustained reduction in unemployment. Along with further structural efforts, they encouraged adoption of permanent concessionary arrangements for labor market entrants.

Directors considered the anticipated further increases in the Riksbank policy rate to be appropriate. The authorities should stand ready to respond flexibly to circumstances, raising rates more rapidly if wage settlements accelerate and delaying somewhat if strong krona appreciation continues. 
Directors welcomed the findings of the recent Financial Sector Assessment Program (FSAP) update, indicating the initial reassurance on credit risks. In light of the potential vulnerabilities stemming from house prices, they called for continued supervisory vigilance. The authorities should be prepared to take further macro prudential measures if significant new financial stability or consumer risks develop.

Directors welcomed recent measures to strengthen the monitoring of liquidity, as well as plans for early introduction of strong liquidity regulations taking specific account of risks in foreign currencies. Given the unique characteristics and risks of the Swedish financial system, Directors supported the authorities' intention to go faster and further than Basel III capital regulations.

Directors also endorsed the FSAP recommendations on institutional issues. These include merging the stability and deposit insurance funds, establishing a special bank resolution regime, increasing further the Financial Supervisory Agency's capacity, and improving coordination among institutions responsible for macro prudential policies.

Public Information Notices (PINs) form part of the IMF's efforts to promote transparency of the IMF's views and analysis of economic developments and policies. With the consent of the country (or countries) concerned, PINs are issued after Executive Board discussions of Article IV consultations with member countries, of its surveillance of developments at the regional level, of post-program monitoring, and of ex post assessments of member countries with longer-term program engagements. PINs are also issued after Executive Board discussions of general policy matters, unless otherwise decided by the Executive Board in a particular case. The staff report (use the free Adobe Acrobat Reader to view this pdf file) for the 2011 Article IV Consultation with Sweden is also available. 
Sweden: Selected Economic and Social Indicators, 2005-12

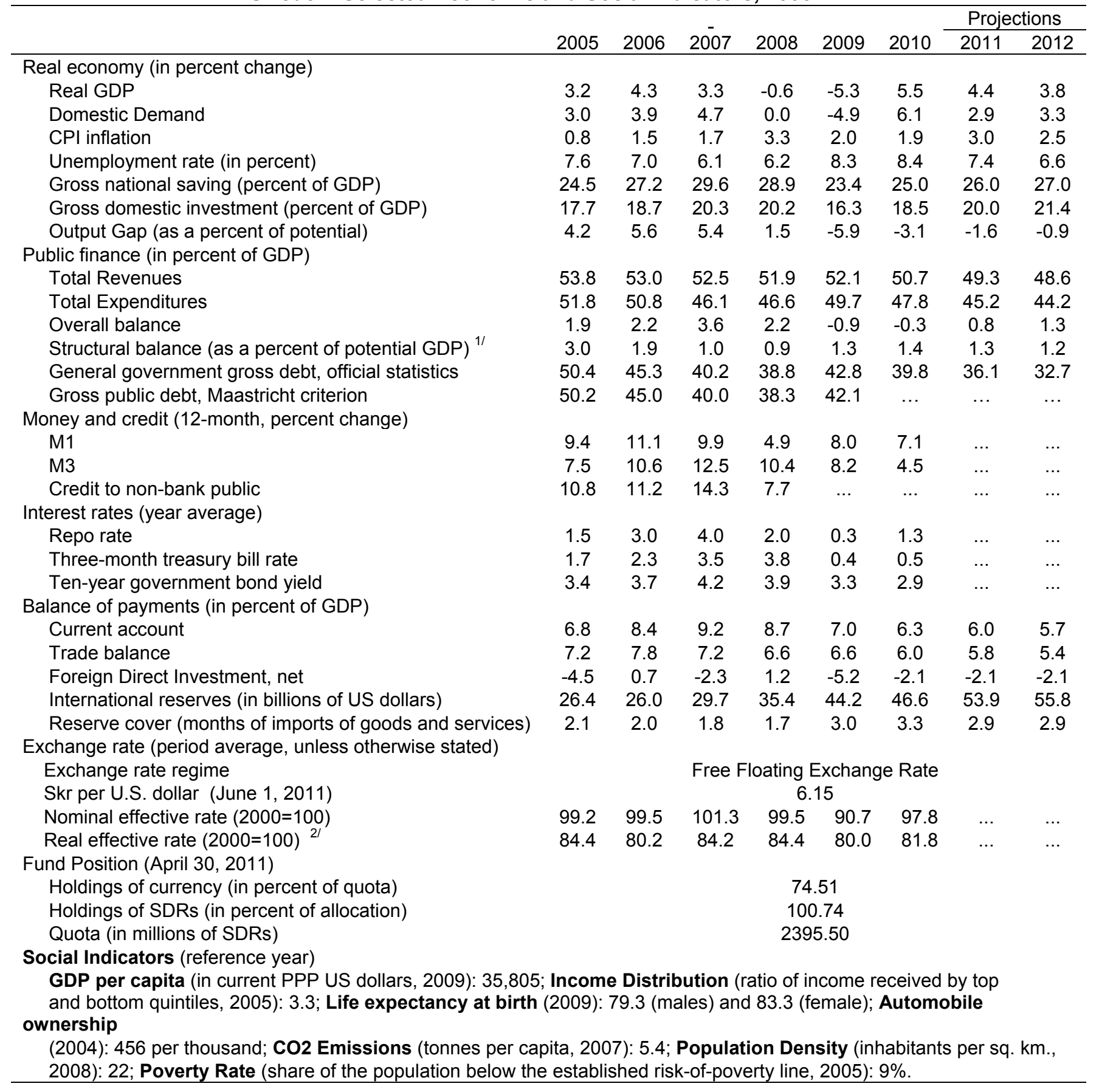

Sources: Statistics Sweden; Riksbank; Ministry of Finance; Datastream; INS; and IMF staff estimates.

1/ IMF Staff Estimates

2/ Based on relative unit labor costs in manufacturing. 


\section{Statement by Benny Andersen, Executive Director for Sweden and Martin Holmberg, Advisor to Executive Director July 8, 2011}

The Swedish authorities would like to express their appreciation for the comprehensive and in-depth analysis of the Swedish economy and financial sector conducted during the Article IV and FSAP missions. Overall, the authorities agree with the main findings of the AIV and FSSA reports.

\section{Short-term outlook and risks}

The authorities broadly share staff's assessment of the short-term outlook and risks. The Swedish economy grew by 5.7 percent in 2010, driven by both export and domestic demand. With the high rate of growth, production volumes have now returned to roughly the same levels as prior to the financial crisis. The recovery has been relatively quick and the economy is expected to grow faster than in many other countries in 2011 at around 4.5 percent. Looking ahead, GDP growth will moderate, and the difference between Swedish and foreign interest rates will decline. Against that background, the exchange rate is projected to remain at roughly the same level as now over the coming years.

The recovery, in combination with structural reforms, has contributed to a strong increase in employment and a decrease in unemployment. Indicators point to continued strong growth in employment as the demand for labor is increasing in most sectors. The rapid improvement in the labor market is expected to lead to higher wage increases. The upcoming wage bargaining rounds are taking place in a much stronger cyclical phase than the previous rounds. The expectation is that wage formation will function smoothly, as it has done over the past 10-15 years, and will give rise to reasonable wage increases.

The authorities agree with staff that considerable uncertainties about the outlook remain. Sweden's public finances are sound, but unfavorable developments of public finances elsewhere may result in heightened financial market stress and reduced external demand. The authorities also agree with staff that house price inflation in Sweden has been noteworthy. Risks associated with the housing market and household debt are therefore monitored closely. In this context, the Riksbank recently published an extensive study of the Swedish housing market. Whether the housing market is overvalued or not is a difficult question, but the authorities agree with staff's view that more data needs to be collected.

\section{Fiscal policy and framework}

The government broadly agrees with staff's view of the Swedish fiscal position and the fiscal policy stance. As they point out, Sweden's fiscal position is strong which makes it possible to continue to support output in the short term without jeopardizing long-run sustainability. Sound public finances are also a corner stone in the work to achieve full employment and greater welfare. 
Returning to a surplus in the public finances is a matter of the highest priority and such an outcome is expected to be achieved already this year. As staff points out, the strong recovery in the Swedish economy implies a more rapid improvement in public finances than was foreseen in the Budget Bill in September 2010. The surplus in the public finances is then expected to gradually rise in the coming years. According to the government's judgment, some scope for reform will emerge in 2012, and this will be compatible with a broadly neutral fiscal stance. Future reform efforts will primarily focus on structurally warranted measures that will strengthen Sweden's long-term growth prospects by increasing employment, decreasing unemployment and improving the functioning of the economy.

However, as staff points out, a number of risks remain which, if realized, may affect public finances negatively. The reform ambitions presented by the government in the 2011 Spring Budget Bill are therefore conditional on the presence of a sustainable scope for new measures. Reforms will only be proposed when it is certain that the surplus target will be met, and the expenditure ceiling not exceeded. It is important that an uncertain scope for reform is not committed in advance and that a new assessment is made prior to each new budget year. The government's view is that it is more responsible to correct an overshooting of the surplus target afterwards, than to be forced to make cuts should downside risks materialize.

The government is also in agreement with staff on the important role played by the Fiscal Policy Council in assessing policy and compliance with the framework. A review of the remit of the council was made recently and no significant changes to its mandate or available resources are expected in the near future.

\section{Monetary policy and framework}

The Executive Board of the Riksbank decided on July 5 to raise the repo rate by 0.25 percentage points to 2.0 percent. The published repo rate path shows a gradual normalization of the repo rate in order to attain the inflation target and keep the real economy stable. At present there is an unusually large difference between the different measures of inflation. The internationally comparable HICP measure, which excludes mortgage costs, is currently at 1.7 percent. While CPI inflation is high, at 3.3 percent in May, as a result of rising mortgage rates, and is expected to remain high above the inflation target of 2 percent during 2011, underlying inflation is low. Higher CPI inflation is due to rising mortgage rates, which is a transitory effect. In periods with large interest rate adjustments, it is thus natural that greater weight is given to measures of underlying inflation when formulating monetary policy.

As resource utilization rises and wages increase at a faster rate, inflationary pressures in the economy are expected to rise gradually over the coming years towards the inflation target of 2 percent. If the currently high CPI inflation rate has a more tangible effect on various agents' long-term inflation expectations and on wage formation, monetary policy may need to be tightened more than in the main scenario. If, on the other hand, the international economic situation becomes weaker, for example, as a result of the fiscal problems in the euro area worsening, the repo rate may need to be raised at a slower pace in the period ahead. 
The authorities welcome staff's assessment that the current monetary and exchange rate regimes have served Sweden well.

\section{Financial sector policy and framework}

\section{Financial Stability Assessment}

The authorities broadly agree with the overall thrust of staff's financial stability assessment. The main risks to financial stability lie in the developments outside of Sweden. The Swedish banks' direct exposure to peripheral euro-area countries is small. However, given the banks' heavy reliance on short-term wholesale funding, in particular in US dollars, the Swedish banks are vulnerable to market disruptions and liquidity risks. Financial stability could thus be affected from indirect channels should the sovereign debt crisis in the euro area worsen. A renewed global recession could also affect bank asset quality given trade dependency and the external financial sector linkages of the Swedish economy. At the same time, Swedish banks are currently well capitalized from an international perspective giving them an adequate cushion should risks materialize. Moreover, the Swedish authorities intend to accelerate the implementation pace of Basel III capital requirements, and impose higher than minimum capital requirements on the largest and systemically important banks. The authorities will also build upon the Swedish experience of early implementation of enhanced liquidity reporting by ensuring that the new Basel III liquidity standards are implemented in an adequate, appropriate and proportionate manner. Given the nature of Swedish banks' exposures and prevailing risks, the authorities are pleased to hear that staff welcomes this stance.

\section{Macroprudential and Financial Stability Framework}

Regarding the suggestion to strengthen coordination mechanisms between various regulatory agencies by establishing a high-level Systemic Financial Stability Council, the authorities would like to note that a Committee has been established to look into this issue and will present recommendations by August 2012. Also, the authorities note that while some aspects of macroprudential policies are related to crisis management and resolution issues, others are not. There are also some legal differences in the possibilities to share data between the different authorities, which need to be resolved. Furthermore, the proposal to include independent members in a macroprudential body could potentially raise confidentiality concerns. Considerable thought should therefore be put into the tasks and composition of any group. Irrespective of an establishment of a macroprudential function the institutional infrastructure among and the mandates of the involved authorities need to be clarified.

\section{Sectoral Regulation and Supervision}

The government intends to take action on a number of recommendations concerning the resources and legal responsibilities of the Financial Supervisory Authority

(Finansinspektionen, FI). The government shares the opinion of the IMF that FI should have sufficient resources and legal powers to carry out efficient supervision, not least with respect to the increasing responsibilities regarding regulation of the financial sector. Therefore, in the Budget Bill for 2012, the government intends to propose to parliament a substantial increase 
in FI's appropriations over a three-year period to strengthen its supervisory and oversight functions.

In this context, the government would like to underline FI's independence; owing to the same provisions that apply to all Swedish authorities, any governmental intervention in specific cases regarding exercise of authority or application of law is strictly prohibited. However, in order to further safeguard the independence of FI, its policy documents will be amended with a provision clearly stating the operational and budgetary independence of the authority. The government will also propose legislative amendments concerning the issue of licensing of regulated entities thereby clarifying FI's sole responsibility in this area.

Regarding the regulation of the banking sector, the Swedish authorities would also like to make a clarification as regards the possibility to appeal administrative decisions. FI would always, unless very specific circumstances are at hand, decide that for example a revocation of a license should have immediate effect. This means that the decision will be applied even though the decision is subject to appeal. For the decision to be suspended, the credit institution must in its appeal demand that the court stay the execution of the decision. The decision is only stayed if the request is granted by the court. Courts do not and should not grant such requests routinely. Actual cases are rare, but the perception is that in almost all cases the decision will be applied even if an appeal is lodged.

During several years, considerable effort has been put into developing cross-border supervision at FI and collaboration in the supervisory colleges. This effort will continue in line with staff recommendations in the FSSA report.

Regarding the insurance sector, several of the issues raised by staff will be dealt with once the new regulatory framework for the sector, i.e. Solvency II, is implemented. Sweden is also participating in ongoing work carried out by IAIS in Internationally Active Insurance Groups, which will contribute to further develop the supervisory standard. Additionally, regulation regarding the transfer of policies as well as other life insurance related issues is currently under national review.

The authorities agree that it is important to further develop not only risk based supervision, but also the level of baseline supervision. FI is currently reviewing the model for baseline supervision and the need for further strengthening will be taken into account in the review of future resources. During the first half of 2011 a pilot review of a number of small insurance companies has been performed.

Regarding the securities markets, the Swedish authorities broadly agree with staff's assessment of compliance with IOSCO principles. As regards independence and resources our view has been expressed above. In relation to enforcement, FI has carefully considered the process for enforcement and sanctions. FI has not found it efficient to establish a separate enforcement department, maintaining the view that adequate provisions and practices are in place to safeguard the interests and fundamental rights of the addressees of FI's potential decision. It should also be made clear that even though direct representations are not made, the addressees are always invited to comment on the findings to be presented to the Board 
before any decisions on sanctions, thereby offering them corresponding possibilities to argue their case, in accordance with general administrative law to be applied by all public agencies.

The Swedish authorities welcome the detailed assessments of NASDAQ OMX Derivatives Markets and of the RIX system made by the IMF. The recommendations are constructive and the authorities look forward to using them in the supervisory and oversight processes. Work has already been initiated in response to many of the views expressed.

Regarding staff's suggestion to ring-fence the operation of NOMX DM in a separate legal entity, the authorities are of the opinion that it is an open question whether a legal separation is necessary as risk reduction may be achieved by other means. Such a measure should only be taken if the benefits in terms of risk reduction outweigh the costs.

The Swedish authorities agree with the assessment of Anti-Money Laundering and AntiTerrorist Financing. Significant resources have been devoted to improving compliance in this area (including the creation of a dedicated unit at FI), and the framework will be developed further. 